\title{
Northern Myotis Roosting Ecology and Use of Prescribed Fire and Herbicide Treatment to Enhance Roost Availability in Hardwood Forests
}

Milu Karp

West Virginia University

Follow this and additional works at: https://researchrepository.wvu.edu/etd

\section{Recommended Citation}

Karp, Milu, "Northern Myotis Roosting Ecology and Use of Prescribed Fire and Herbicide Treatment to Enhance Roost Availability in Hardwood Forests" (2013). Graduate Theses, Dissertations, and Problem Reports. 4974.

https://researchrepository.wvu.edu/etd/4974

This Thesis is protected by copyright and/or related rights. It has been brought to you by the The Research Repository @ WVU with permission from the rights-holder(s). You are free to use this Thesis in any way that is permitted by the copyright and related rights legislation that applies to your use. For other uses you must obtain permission from the rights-holder(s) directly, unless additional rights are indicated by a Creative Commons license in the record and/ or on the work itself. This Thesis has been accepted for inclusion in WVU Graduate Theses, Dissertations, and Problem Reports collection by an authorized administrator of The Research Repository @ WVU. For more information, please contact researchrepository@mail.wvu.edu. 
Northern Myotis Roosting Ecology and Use of Prescribed Fire and Herbicide Treatment to Enhance Roost Availability in Hardwood Forests

Milu Karp

Thesis submitted to the

Davis College of Agriculture, Natural Resources and Design

at West Virginia University

in partial fulfillment of the requirements

for the degree of

Master of Science

In

Wildlife \& Fisheries Management

John W. Edwards, Ph.D., Chair

Tom Schuler, Ph.D.

Sheldon Owen, Ph.D.

Division of Forestry and Natural Resources

Morgantown, West Virginia

2013

Keywords: Northern myotis; Myotis septentrionalis; Decay stage, Prescribed fire; Roost use;

Snag dynamics, Survival, West Virginia

Copyright 2013 Milu Karp 


\section{ABSTRACT \\ Northern Myotis Roosting Ecology and Use of Prescribed Fire and Herbicide Treatment to Enhance Roost Availability in Hardwood Forests}

\section{Milu S. Karp}

Recent declines in myotis populations throughout the mid-Atlantic region due to habitat degradation and the spread of white-nose syndrome have led to the increased need for understanding of roost ecology to aid in population recovery. Land management agencies in the Central Appalachian Hardwood Region can contribute to the conservation and possible recovery of northern myotis through habitat creation by means of prescribed fire. Within the Fernow Experimental Forest in West Virginia, three separate compartments were subjected to prescribed fire to better understand the effects of disturbance on summer roost tree use. During the summer of 2011 and 2012, Northern myotis were captured using mist nets and attached with radio transmitters. In burned and unburned areas, 38 roost trees were located and measurements were taken on the individual roost tree and the area surrounding each roost tree, including species, size, canopy gap, distance to neighboring trees, aspect and slope at roost tree locations. Black locust was the most utilized tree species, followed by red maple and red oak. Roosts were located in trees with cavities, loose bark, and crevices; $57 \%$ of female and $40 \%$ of male roosts were in snags. Both female and male northern myotis were found roosting in burned and unburned areas, while female northern myotis used roosts surrounded with larger canopy gaps overhead. Roosts in unburned areas had a smaller percent canopy closure and were located on steeper slopes. Slope at roost locations was significantly different between both female and male roost locations as well as between roosts in burned areas and unburned areas. As the burned compartments within the FEF continue to decay and forest regeneration is allowed to progress, the effect of fire disturbance on roosting ecology can be better quantified and this may allow forest managers to develop predictive models for roost tree creation and use on a local and landscape scale. Snags with cavities and exfoliating bark are an important component of stand structure for wildlife in hardwood forests. Understanding changes in decaying trees over time is needed to manage cavity-dependent biota. I quantified short-term (2006 - 2012) rates of initial tree death and progression through decay stages following fire and herbicide treatments initially applied in the spring of 2007 in the Alleghany Plateau of West Virginia. Red maple, chestnut oak, northern red oak and sugar maple were the most prevalent species found in measured plots. Northern red oaks were found to live the longest following fire treatment while black locusts were found to decay fastest after treatment. The greatest decline in trees in all treatments was in 2008, one year following initial fire and/or herbicide treatment, with a more gradual decline following in 2012. Transition of trees among decay classes differed by species and size. Prescribed fire alone had the least impact on overall mortality and decay progression for the treatments. Fire tolerance was also positively correlated with tree size, with yellow-poplar having the lowest mortality rate after prescribed fire treatment. Prescribed fire remained the least impactful treatment in rapid progression of trees through decay stages. Plots subjected to herbicide treatment for all non-oak and hickories found with $>12.7 \mathrm{~cm}$ dbh showed a more rapid rate of decline than both fire only and midstory treatment areas. Snag longevity was significantly greater with increasing diameter for all treatments. Silvicultural practices that increase tree mortality rates and snag retention 
over long periods of time could be a beneficial approach to management for cavity-dependent wildlife in hardwood forests. 


\section{ACKNOWLEDGMENTS}

I would first like to thank my advisor, Dr. Edwards, for providing me with an interesting and beneficial research opportunity and for taking a chance on a technician-turned teacher-turned graduate student. Also, my research would not have been successful without the help of my committee members Dr. Sheldon Owen and Dr. Thomas Schuler. A big thank you to Jane Rodrigue, ecologist for the USDA Forest Service, who was a tremendous help in the capturing and tagging of bats as well as searching for roosts over and through the woods. I would also like to thank my funding sources, the West Virginia Division of Natural Resources and the USDA Forest Service Northern Research Station. Thank you also to the personnel of the Northern Research Station Forest Service Office, namely Donald Lowther and Richard Hovatter, who were invaluable in assisting with vegetation surveys and adding humor to a tough day in the field. I would like to thank my fellow student Andrew Tri for assistance with statistical analysis. A big thank you to Justin Lewis, a truly hardworking field assistant and hilarious "measurer" of trees who somehow found himself on the sides of steep mountains in the middle of a West Virginia summer, armed with only a compass and a sandwich. Lastly, I would like to thank my parents, whose constant and enthusiastic support of my education and passions have taken me around the world. 


\section{TABLE OF CONTENTS}

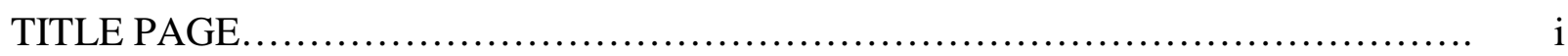

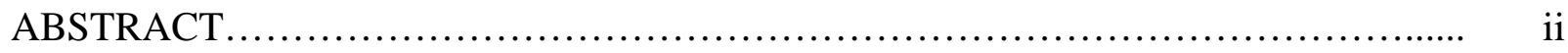

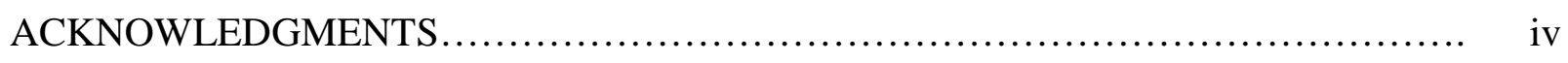

TABLE OF CONTENTS .............................................................. iv

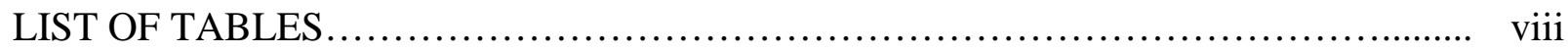

LIST OF FIGURES.................................................................. ix

LIST OF APPENDICES...............................................................

INTRODUCTION, JUSTIFICATION, AND RESEARCH OBJECTIVES................... 1

Introduction and Justification.................................................. 1

Research Objectives...................................................... 4

Literature Cited................................................................. 5

CHAPTER 1: BAT ECOLOGY AND SILVICULTURE LITERATURE REVIEW........ 9

Silviculture and Snag Creation................................................. 10

Roost Ecology in Forest Management.............................................. 13

Bat Ecology and Life History ..................................................... 19

Northern Myotis Ecology ........................................................ 21

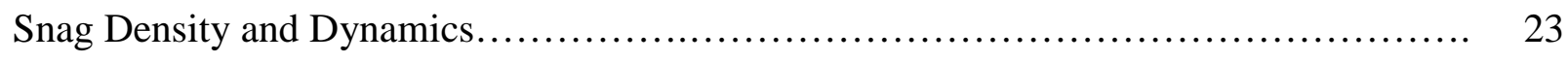

LITERATURE CITED ........................................................... 25 
CHAPTER 2: ROOST TREE USE OF NORTHERN MYOTIS

(Myotis septentrionalis) IN A CENTRAL APPALACHIAN HARDWOOD FOREST.... 37

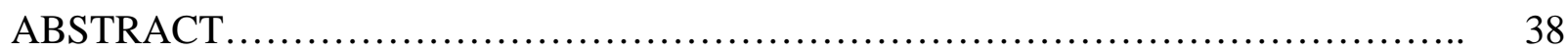

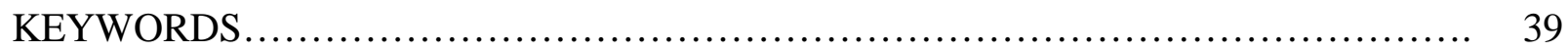

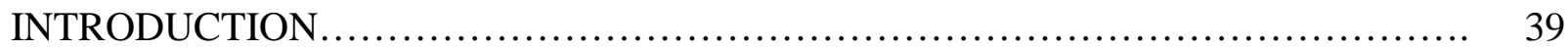

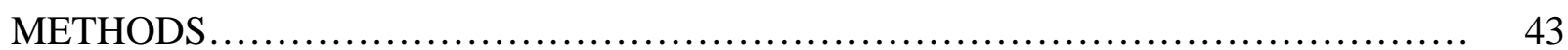

Study Area.............................................................. 43

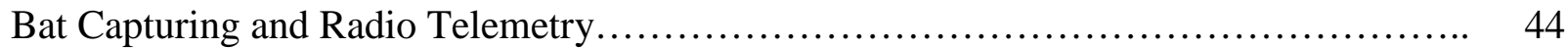

Habitat and Vegetation Measurements..................................... 45

Statistical Analysis...................................................... 46

RESULTS...................................................................... 47

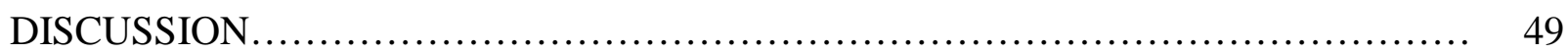

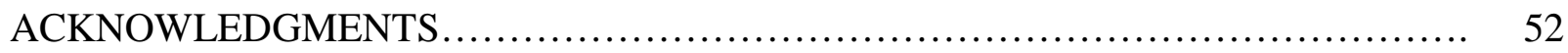

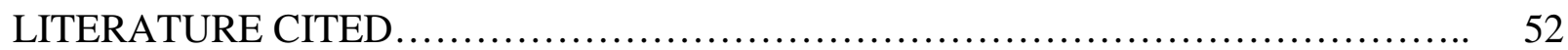

CHAPTER 3: EFFECT OF PRESCRIBED FIRE AND HERBICIDE TREATMENT ON

SNAG DYNAMICS IN A HARDWOOD FOREST IN WEST VIRGINIA............. 72

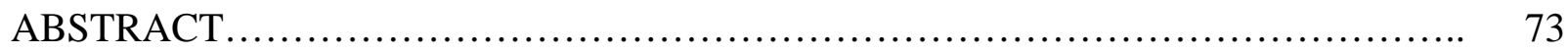

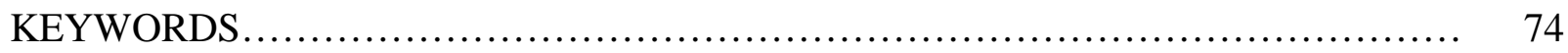

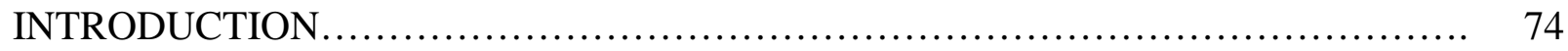

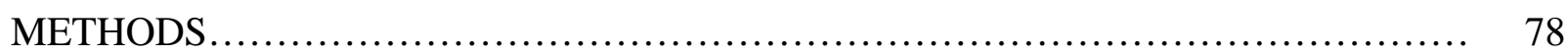




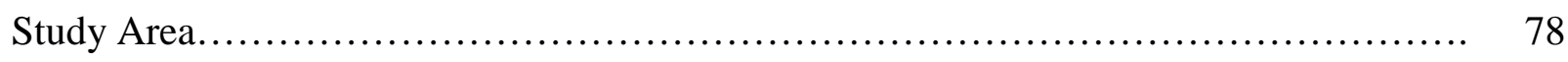

Data Collection.................................................................. 80

Quantifying Mortality Rates................................................... 80

Quantifying Snag Progression and Survival...................................... 80

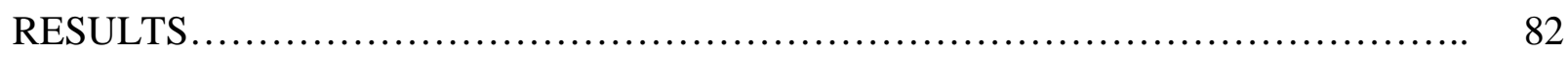

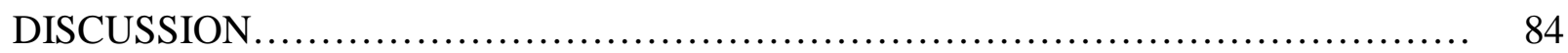

ACKNOWLEDGMENTS.................................................... 88

LITERATURE CITED .......................................................... 88 


\section{LIST OF TABLES}

Table 2.1. Roost tree species used by Myotis septentrionalis on the Fernow Experimental Forest, 2011 and 2012.

Table 2.2. Distribution of Myotis septentrionalis roosts in live trees and snags in the Fernow Experimental Forest, 2011 and 2012.

Table 2.3. Myotis septentrionalis roost trees located in burned and unburned areas in the Fernow Experimental Forest, 2011 and 2012. Pearson's g-test for goodness of fit between sex and burn with adjusted g-values for small sample size.

Table 2.4. Myotis septentrionalis roost tree and site characteristics on the Fernow Experimental Forest, 2011 and 2012.

Table 2.5. Myotis septentrionalis roost tree and site characteristics in burned and unburned areas in the Fernow Experimental Forest, 2011 and 2012.

Table 3.1. Percent mortality for tree species (>1\% frequency) subjected to FIRE treatment in the Fernow Experimental Forest, West Virginia, 2012.

Table 3.2. Comparison of decay class by treatment excluding oaks and hickories for plots measured between 2006 and 2012 in the Fernow Experimental Forest. 


\section{LIST OF FIGURES}

Figure 2.1. Roost tree species used by female and male northern myotis by size $(\mathrm{dbh} \mathrm{cm})$ in 2011 and 2012 in the Fernow Experimental Forest.

Figure 2.2. Northern myotis roost tree locations within the Fernow Experimental Forest, Tucker County, West Virginia, 2011 and 2012.

Figure 3.1. Percent trees present in decay stage in 2006 and 2012 and progression among decay stages by treatment type excluding oaks and hickories in the Fernow Experimental Forest, 20062012.

Figure 3.2. Probability of trees excluding oaks and hickories surviving from 2006 to 2012 based on response to one of three treatments, on the FEF. FIRE $=$ fire only; MIDSTORY $=$ fire + herbicide (all non-oaks 12.7-27.9 cm dbh); OVERSTORY = fire + herbicide (all non-oaks 12.7+ $\mathrm{cm})$.

Figure 3.3. Probability of trees excluding oaks and hickories surviving from 2006 to 2012, based on size clas, on the FEF. Size class: $1=10-19.9 \mathrm{~cm}, 2=20-29.9 \mathrm{~cm}, 3=30-39.9 \mathrm{~cm}, 4=40$ $59.9 \mathrm{~cm}, 5=60-79.9 \mathrm{~cm}, 6=80-100 \mathrm{~cm}$.

Figure 3.4. Probability of trees excluding oaks and hickories surviving from 2006 to 2012, based on size class within treatment. Size class: $1=12.7-19.9 \mathrm{~cm}, 2=20-29.9 \mathrm{~cm}, 3=30-39.9 \mathrm{~cm}, 4=$ 40-59.9 $\mathrm{cm}, 5=60-79.9 \mathrm{~cm}, 6=80-100 \mathrm{~cm}$. FIRE $=$ fire only; MIDSTORY $=$ fire + herbicide (all non-oaks 12.7-27.9 cm dbh); OVERSTORY = fire + herbicide $($ all non-oaks $12.7+\mathrm{cm})$. Figure 3.5. Three compartments established in 2006 on the Fernow Experimental Forest and fire/herbicide plots, Tucker County, West Virginia. 


\section{LIST OF APPENDICES}

Appendix 2.a. Treatment type and timeline of treatment application for 3 compartments in the Fernow Experimental Forest, West Virginia, 2006 - 2012.

Appendix 2.b. Total and divided area of compartments and areas of treatments by acre and hectare, including percent area of treatment plots established in 2006 in the FEF.

Appendix 2.c. Decay stage designation and the characteristics of trees in those decay stages (based on decay of Douglas-fir snags as adapted by Maser et al. 1979).

Appendix 2.d. Crown class designation and associated characteristics of trees in those classes (USDA Forest Service).

Appendix 2.e. Characteristics of roost trees used by Myotis septentrionalis in areas that were and were not subjected to prescribed fire on the Fernow Experimental Forest, 2011 and 2012. Appendix 2.f. Characteristics of roost trees used by female and male Myotis septentrionalis on the Fernow Experimental Forest, 2011 and 2012.

Appendix 3.a. Common species and shade tolerance ratings of trees found in the Fernow Experimental Forest, West Virginia, 2011 and 2012 (Silvics of Forest Trees of the United States, USDA Forest Service 1965).

Appendix 3.b. Common hardwood species in the Fernow Experimental Forest (>1\% frequency) by vulnerability, to long-term repeated burning (Gleason 1913, Garren 1943, Curtis 1959, Heinselrnan 1973, Grimm 1984, Harmon 1984, Lorimer 1985, Burns and Honkala 1990, Boyer 1990, 1993, Nowacki and Abrams 1992, Orwig and Abrams 1994, Huddle and Pallardy 1996, Hicks 1998, Brose and Van Lear 1998).

Appendix 3.c. Total and divided area of compartments and areas of treatments by acre and hectare, including percent area of treatment plots established in 2006 in the FEF. 
Appendix 3.d. Decay stage designation and the characteristics of trees in those decay stages (USDA Forest Service based on decay of Douglas-fir snags as adapted by Maser et al. 1979). Appendix 3.e. Commonly used crown classes and the characteristics of trees in those classes (Kraft 1884; Oliver and Larson 1990; Smith et al. 1997; Helms 1998).

Appendix 3.f. Treatment type used in the three treatment compartments in the FEF (USDA Forest Service). 


\section{INTRODUCTION, JUSTIFICATION, AND RESEARCH OBJECTIVES}

In recent decades, significant attention has been given to the management and conservation of forest-dwelling bats to promote the recovery of populations under threat from habitat degradation, disturbance to hibernacula, and disease (Tuttle 1979, Fenton 2003). This focus is due to their important ecological roles as nocturnal insectivores and as possible indicator species of forest ecosystem health (Fenton 2003). Myotid bats have suffered substantial declines and represent the largest and most widely distributed group of bats in North America (Reid 2006). Human disturbance of hibernacula, environmental pollution, and loss of summer habitat (Tuttle 1979, Pierson 1998, Fenton 2003) have led to population declines, resulting in the listing of several bat species under the Endangered Species Act, as well as listing as species of concern (Harvey et al. 1999). Recent declines in myotis populations in the eastern United States and throughout the mid-Atlantic region due to habitat degradation and the spread of white-nose syndrome (Geomyces destructans), have led to a need for increased understanding of roost ecology (winter hibernacula and summer roost trees) to aid in population recovery. The primary focus has been protection of myotis hibernacula in an attempt to increase population size. Attempts to protect hibernacula have led to population increases for species such as gray myotis (Myotis grisescens), Indiana myotis (M. sodalis), and Virginia big-eared bats (Corynorhinus townsendii virginianus) (Clawson 2002, Martin et al. 2003). Although the protection of winter hibernacula is important, more recent effort has focused on understanding the broader range of habitat needs, including summer roost habitat. A complete range of habitat needs, both during winter and summer seasons, is necessary to understand the full scope of habitat requirements when planning for management and protection of species. 
Information on day-roost selection is necessary for guiding and assessing forest management decisions to improve and protect declining bat populations (Arnett 2003). Various intensities of forest harvesting, ranging from clear-cutting to single-tree selection, have the potential to create forest structure that can affect roost selection of bats (Owen et al. 2004). One silvicultural practice that is being considered beneficial for both forest regeneration and habitat creation in hardwood forests is prescribed fire (Johnson et al. 2009). As prescribed fire continues to aid in promoting oak regeneration in the Central Hardwood Forest region, this practice may also benefit bats (Johnson et al. 2010). Although fire may reduce the longevity or utility of individual roost trees, it may also kill or scar other trees in the vicinity, creating suitable bat habitat in the form of loose bark or snags (Russell et al. 2006). Moreover, trees killed by fire will leave gaps in the canopy as they lose limbs and fall, thus increasing solar radiation that can reach lower surfaces of surrounding trees, where bats may be found (Menzel et al. 2001). Increased solar radiation may be a preferred characteristic of roost sites, as warmer temperatures facilitate more rapid development of neonates (Sedgeley 2001, Boyles and Aubrey 2005).

As the use of prescribed fire in forest management gains acceptance in eastern forests, little is known about its implication for forest-dwelling wildlife. For myotis bats, fire will serve to improve roosting habitat by increasing snag availability as well as increasing solar radiation at roost sites (Brooks and Ford 2006, Johnson et al. 2010). More specifically, several species of bats that occur in the central Appalachians of West Virginia rely on trees and snags for summer maternity roosts as well as roosts for individual male bats, including the northern myotis (Myotis septentrionalis) and the federally endangered Indiana bat. Declining populations of these bats are attributed to complex, multi-factor causes, such as exposure to pesticides (Clark 1988), alteration of foraging habitat (Hill and Smith 1984), disturbance of hibernacula (Tuttle 1979), 
and destruction of maternity roost habitat, which may outweigh all others as the ultimate cause for the decline in many species (Kunz 1982). The northern myotis has been found to use roosts in disturbed landscapes with increased snags and larger canopy gaps (Menzel et al. 2002); whether these roosts will support increased productivity and recruitment remains to be fully determined.

The potential of using prescribed fire to create suitable roost conditions, in either live trees or snags, for bats is a largely unexplored, but a potentially valuable area of research (Leput 2004, Boyles and Aubrey 2005, Loeb and Waldrop 2008). Recently, prescribed fire has served a dual purpose in the Appalachian Mountains and Central Hardwoods Forest regions: one of hardwood regeneration and shade-tolerant tree species suppression. Insufficient retention and/or regeneration of hard-mast producing oaks (Quercus spp.) and hickories (Carya spp.) in managed and unmanaged forest stands are major concerns of forest and wildlife managers. The failure to adequately maintain oak has been attributed in part to fire suppression and uneven-age management practices that favor shade-tolerant tree species such as maples (Acer spp.) (Clark 1993, Schuler and Fajvan 1999, Brose et al. 2001, Schuler 2004, Nowacki and Abrams 2008). Oak regeneration can benefit from a combination of prescribed fire and forest canopy thinning by tree removal, girdling, or herbicide of competitors, to augment oak seedling initiation and survival through reduced competition and increased canopy openness (Miller 1993, Brose et al. 1999, Brose et al. 2001). The use of fire and herbicide for the regeneration of oak is therefore important in the disturbance it creates. These methods increase snag abundance that in turn favor snag-dependent wildlife species, including bats (Brose et al. 2001, Hallett et al. 2001, Albrecht and McCarthy 2006, Boyles and Aubrey 2005). 


\section{Research Objectives}

The primary objectives of this study were to:

(1) Examine the differences in roost sites of northern myotis in forested stands subjected to prescribed fire (burned) and in unburned forested stands.

(2) Compare roost site use between female and male northern myotis in burned and unburned stands.

(3) Identify quantitative changes in snag decay and survival dynamics in a second- and thirdgrowth hardwood forest.

(4) Estimate the probability of snag survival using decay stage.

(5) Quantify the effect of fire and herbicide on tree progression through stages of decay.

I determined if bats were using areas of burn and herbicide treatment more consistently than areas of control, and if this may was due to creation of adequate cavity/bark characteristics in areas of prescribed fire. I predicted that (1) northern myotis would select roosts in areas subjected to prescribed fire and herbicides, and that use would be related to tree decay class, canopy exposure, solar radiation, and tree species; (2) northern myotis would use newly-created snag and scarred trees (including exfoliating bark) for roosting within burn treatments more than non-treatment reference areas and (3) roost trees selected by female northern myotis would differ from male myotis in canopy exposure and tree species.

I predicted that (1) size class of hardwood trees would be positively related to fire tolerance and that all species allowed to reach a larger size class would remain tolerant to prescribed fire and herbicide regardless of bark thickness, (2) trees injected with herbicide would decline at a rapid rate compared to trees subjected to fire only, and (3) herbicide would be effective in eliminating smaller diameter trees of various species. 


\section{LITERATURE CITED}

Albrecht, M. A., B. C. McCarthy. 2006. Effects of prescribed fire and thinning on tree recruitment patterns in central hardwood forests. Forest Ecology and Management 226: $88-103$.

Arnett, E. B. 2003. Advancing science and partnerships for the conservation of bats and their habitats. Wildlife Society Bulletin 31: 2-5.

Boyles, J. G., D. P. Aubrey. 2005. Managing forests with prescribed fire: implications for a cavity-dwelling bat species. Forest Ecology and Management 222: 108-115.

Brooks, R. T., W. M. Ford. 2006. Introduction to the special section - bat habitat use in eastern North America temperate forests: site, stand, and landscape effects. Journal of Wildlife Management 70: 1171-1173.

Brose, P. D., D. VanLear, R. Cooper. 1999. Using shelterwood harvests and prescribed fire to regenerate oak stands on productive upland sites. Forest Ecology and Management 113: $125-141$.

Brose, P., T. Schuler, D. Van Lear, J. Berst. 2001. Bringing fire back: The changing regimes of the Appalachian mixed-oak forests. Journal of Forestry 99: 30-35.

Clark, D. R. Jr. 1988. Environmental contamination and management of bat populations in the United States. Pp. 409-413 in Management of Amphibians, Reptiles and small mammals in North America: proceedings of the symposium, July 19-21, 1988, Flagstaff, Arizona.

Clark, F. B. 1993. An historical perspective of oak regeneration. Pages 3-13 In D. Loftis, and C. E. McGee, editors. Proceedings, Oak regeneration: serious problems, practical recommendations; 1992 September 8-10; Knoxville, Tennessee. General Technical 
Report SE-84. USDA Forest Service, Southern Research Station, Asheville, North Carolina.

Clawson, R. L. 2002. Trends in population size and current status. Pages 2-8. In A. Kurta and J. Kennedy, editors. The Indiana bat: biology and management of an endangered species. Bat Conservation International, Austin, Texas.

Fenton, M. B. 2003. Science and the conservation of bats: where to next? Wildlife Society Bulletin 31: 6-15.

Hallett, J. G., T. Lopez, M. A. O’Connell, M. A. Borysewicz. 2001. Decay dynamics and avian use of artificially created snags. Northwest Science 75: 378-386.

Harvey, M. J., J. S. Altenbach, T. L. Best. 1999. Bats of the United States. Arkansas Game and Fish Commission and U. S. Fish and Wildlife Service, Little Rock, Arkansas.

Hill, J. E., J. D. Smith. 1984. Bats: a natural history. University of Texas Press. Austin.

Johnson, J. B., J. W. Edwards, W. M. Ford, J. E. Gates. 2009. Roost tree selection by northern myotis (Myotis septentrionalis) maternity colonies following prescribed fire in a central Appalachian hardwood forest. Forest Ecology and Management 258: 233-242.

Johnson, J. B., W. M. Ford, J. L. Rodrigue, C. M. Johnson. 2010. Roost selection by male Indiana myotis following forest fires in central Appalachian hardwood forests. Journal of Fish and Wildlife Management 15: 39-48.

Kunz, T. H. 1992. Roosting ecology. In Kunz TH (ed) Ecology of bats. Plenum Press, New York, pp 1-55.

Leput, D. W. 2004. Eastern red bat (Lasiurus borealis) and eastern pipistrelle (Pipistrellus subflavus) maternal roost selection: implications for forest management. M.S. Thesis. Clemson University, Clemson, South Carolina. 
Loeb, S. C., T. A. Waldrop. 2008. Bat activity in relation to fire and fire surrogate treatments in southern pine stands. Forest Ecology and Management 255: 3185-3192.

Martin, K. W., D. M. Leslie, Jr., M. E. Payton, W. L. Puckette, S. L. Hensley. 2003. Internal cave gating for protection of colonies of the endangered gray bat (Myotis grisescens). Acta Chiropterologica 5: 151-160.

Menzel, M. A., S. F. Owen, W. M. Ford, J. W. Edwards, P. B. Wood, B. R. Chapman, and K. V. Miller. 2002. Roost tree selection by northern long-eared bat (Myotis septentrionalis) maternity colonies in an industrial forest of the central Appalachian Mountains. Forest Ecology and Management 155: 107-114.

Menzel, M. A., Carter, T.C., Ford, W.M., Chapman, B.R., 2001. Tree-roost characteristics of subadult and female adult evening bats (Nycticeius humeralis) in the upper Coastal Plain of South Carolina. 0American Midland Naturalist 145: 112-119.

Miller, J. H. 1993. Oak plantation using mechanical, burning, and herbicide treatments. Pages 264-289 In D. Loftis, and C. E. McGee, editors. Proceedings, Oak regeneration: serious problems, practical recommendations; 1992 September 8-10; Knoxville, Tennessee. General Technical Report SE-84. USDA Forest Service, Southern Research Station, Asheville, North Carolina.

Nowacki, G. J., M. D. Abrams. 2008. The demise of fire and "mesophication" of forests in the eastern United States. BioScience 58: 123-138.

Owen, S. F., M. A. Menzel, W. M. Ford, J. W. Edwards, J. M. Menzel, B. R. Chapman, P. B. Wood, K. V. Miller. 2004. Bat activity in harvested and intact forest stands in the Allegheny Mountains. Northern Journal of Applied Forestry 21: 154-59. 
Pierson, E. D. 1998. Tall trees, deep holes, and scarred landscapes; conservation biology of North American bats. Pages 309-325 In T. H. Kunz and P. A. Racey, editors. Bat biology and conservation. Smithsonian Institution Press, Washington, D.C.

Reid, F. A. 2006. Peterson's field guide to mammals of North America north of Mexico. Houghton Mifflin Company. New York.

Russell, R. E., V. A. Saab, J. G. Dudley, J. J. Rotella. 2006. Snag longevity in relation to wildfire and postfire salvage logging. Forest Ecology and Management 232: 179-187.

Sedgeley, J. A. 2001. Quality of cavity microclimate as a factor influencing selection of maternity roosts by a tree-dwelling bat, Chalinolobus tuberculatus, in New Zealand. Journal of Applied Ecology 38: 425-438.

Schuler, T. M., M. A. Fajvan. 1999. Understory tree characteristics and disturbance history of a central Appalachian forest prior to old-growth harvesting. USDA Forest Service, Res. Pap. NE-710, Northeastern Research Station, Radnor, PA.

Schuler, T. M. 2004. Fifty years of partial harvesting in a mixed mesophytic forest: composition and productivity. Canadian Journal of Forest Research 34: 985-997.

Tuttle, M. D. 1979. Status, causes of decline, and management of endangered gray bats. Journal of Wildlife Management 43(1): 1-17. 


\section{CHAPTER 1}

BAT ECOLOGY AND SILVICULTURE

LITERATURE REVIEW 


\section{LITERATURE REVIEW}

\section{Silviculture and Snag Creation}

After decades of fire suppression in the forests in Appalachia, prescribed fire is now gaining acceptance as a management technique to aid in regeneration of oak in hardwood forests. Very little is known about the impact of fire on sensitive forest-dwelling wildlife (Boyles et al. 2005). The northern myotis is one such forest-dependent species. At a time when populations are being dramatically affected by the white-nose syndrome and habitat loss due to the roost degradation and human development, it is imperative to gain a better understanding of the impacts of forest management and silviculture on sensitive species.

Silviculture can be defined as the science and art of manipulating a stand of trees toward a desired future condition (Guldin et al. 2007). Contemporary forest management goals include health, diversity, productivity, and sustainability of ecosystems. A silviculturist sees a forest stand as a collection of individual trees, each of which uses resources according to its size and species attributes (Guldin et al 2007). Silvicultural practices enable trees to grow faster, so that desired stand conditions can be achieved more rapidly. Unwanted competitors can be removed through felling, girdling, use of herbicides, top-killing with fire, or any other practice that effectively reduces or eliminates the ability of undesirable plants to compete with desired individuals. Different silviculture practices will promote different wildlife and foraging habitats, which will favor different species of bats. For example, the little brown bat (M. lucifugus) forages along edges of clear-cuts while the northern myotis prefers to forage in intact forests (Patriquin and Barclay 2003). Ideally, these differing habitat regimes can be created through particular silvicultural techniques. 
The limited information available does suggest a positive relation between number of large-diameter snags and the abundance of bats (Hayes and Loeb 2007). Along with exposure to pesticides (Clark 1988), alteration of foraging habitat (Hill and Smith 1984) and disturbance of hibernacula (Tuttle 1979), destruction of maternity roost habitat used in summer may outweigh all others as the ultimate cause for the decline in many species (Kunz 1982). The availability of suitable snags therefore is considered to be the most important factor in sustaining populations of cavity-nesting species (McClelland et al. 1979). One of the most immediate and direct ways that forest management activities influence bat habitat is their impact on number of roosts in an area. Removal of actual and potential roost sites is common during timber harvest (Hayes and Loeb 2007). Humes et al. (1999) found that bat presence was higher both in old growth stands and in thinned stands than in unthinned stands. Structural changes caused by thinning may benefit bats by creating habitat structure in young stands that bats are able to use more effectively (Humes et al. 1999).

Prescribed fire is often designated as a tool to release nutrients stored in leaf litter and woody material and to top-kill seedlings and stump sprouts not adapted to fire (Guldin et al. 2007). In the Central Hardwood Forests region of West Virginia, fire is becoming a common denominator for the development of oak forests (Abrams 1992). Prescribed burning also appears to initially lead to creation or restoration of favorable cavity-dwelling bat habitat and its continual implementation perpetuates an open sub-canopy (Boyles and Aubrey 2005). Prescribed fire in forest management may create additional roost resources, depending on spatial context (Johnson et al. 2010).

Fire initially leads to an increase of dead and dying trees and results in greater light availability, and a decrease of canopy and sub-canopy tree density. These characteristics are 
beneficial to many forest-dwelling vertebrates like cavity-roosting bats (Boyles and Aubrey 2005) including the northern myotis. Further research indicates that prescribed fires alter forest structure in a way that is favorable to bats that roost in tree cavities or under exfoliating bark (Boyles and Aubrey 2006). An increase in light availability may release bats from one of the constraints suggested for many forest-dwelling bat species in roost tree selection: that of sun exposure (Boyles and Aubrey 2005). Just as quality of burned forests varies dramatically with time-since-fire for cavity-nesting birds (Saab et al. 2004), rapid changes in condition of dead trees in years after fire probably influence suitability of snags for bats (Hayes and Loeb 2007). Another challenge is that prescribed fires create relatively few snags (Horton and Mannan 1988) and many of these are small in diameter (Tiedmann et al. 2000). Small diameter snags are relatively poor roost sites for most species of bats (Barclay and Kurta 2007).

Stand age alone is not an adequate predictor of habitat use by bats (Humes et al. 1999), but forest managers can influence roost abundance by augmenting snag availability via snag creation. It is suspected that significant use of created snags by bats does not occur for several years following their creation because of the time lag associated with deterioration in integrity of bark (Hayes and Loeb 2007). Cavity-nesting species use anthropogenically-created snags for foraging and nesting, but there are differences in this use due to treatment method, degree of decay, and tree species (Hallet et al. 2001). Silviculture can also affect the environmental context in which a roost occurs - through alteration of conditions around a roost, and consequently the thermal characteristics of roost sites (Hayes and Loeb 2007).

Because bats spend considerable time roosting, thermal dynamics play a critical role in ecology of bats (Barclay and Kurta 2007). Sedgeley (2001) compared the microclimate characteristics of bat roosts in New Zealand and found that the temperatures both in used and 
potential roosts were relatively stable despite large fluctuations in ambient conditions. The temperature and humidity in occupied roosts were consistently higher than in potential but unoccupied sites and used roosts had a relative humidity that was almost constantly $100 \%$ (Hayes and Loeb 2007). In roosts located in tree hollows or beneath loose bark, thermal benefits were influenced by wall thickness and state of decay (Kurta 1996). Also, roost orientation on a particular tree and position of the tree within the forest canopy will influence the amount of sunlight reaching the roost and the degree to which the roost will be heated (Vonhof and Barclay 1996).

Thermal characteristics of trees are influenced by many factors, including size, density, conductivity, specific heat of wood, color and characteristics of bark, and exposure of trees to solar radiation and wind (Potter and Andresen 2002). Johnson et al. (2010) determined that within areas subjected to fire, northern myotis maternity colonies were more likely located in cavity trees that were smaller in diameter, higher in crown class, and located in stands with lower basal area, gentler slopes, and higher percentage of fire-killed stems than random trees. Northern myotis also responded favorably to prescribed fire by exploiting trees, mostly black locust (Robinia pseudoacacia) that were located in canopy gaps that were created by the senescence and decay of surrounding overstory trees (Johnson et al. 2010). Overall, understanding quantitative relations of abundance and viability of bat populations with habitat characteristics at multiple spatial scales is central to understanding the response of bats to forest management and to shaping management recommendations (Hayes and Loeb 2007).

\section{Roost Ecology in Forest Management}

The structure of forest habitat affects the composition of bat communities directly because of constraints such as echolocation and morphology and indirectly through the types of insects 
present (Brigham 2007). A number of studies in various parts of the world have indicated that there is a relation between wing morphology and feeding ecology. Aldridge et al. (1987) found significant correlations between wing morphology and echolocation call design, and maneuverability and habitat use in insectivorous bats in North America. In another study of old world fruit bats, small differences in wing morphology were found to be ecologically significant to the vertical stratification of bats (Hodgkison et al. 2004). Buford et al. (1995) proposed that vegetative structure and plant diversity are related to the production of prey for bats. The possibility that bats select foraging areas based on vegetation structure raises questions about habitat use (Brigham 2007).

Studies have provided evidence that tree-roosting bats select roost trees with particular attributes from among the trees that are available (Barclay and Kurta 2007). Older forests, thinned mature forests with reduced mid-stories, and greenbelts (areas of largely undeveloped, wild, or agricultural land otherwise surrounded by urban development) retained in harvested areas are all important roosting habitats. The variation in habitat preferences emphasizes the importance of open forest conditions and a diversity of stand types for bat communities in southeastern United States (Barclay and Kurta 2007). Vonhof and Barclay (1996) found that myotis bats in British Columbia will select taller trees surrounded by an open canopy, compared to other trees available in the area. Reproductive female bats may benefit energetically by selecting roosts that are heated by the sun for at least part of the day. The orientation of roosts to the sun (i.e. southern and western-facing exposure) will contribute to the amount of heat reaching roosts. Absolute tree height is also a good discriminator between roost and available trees, but height of the tree relative to the canopy is not substantial enough to impact selection. It is suggested that bats may select tall trees to reduce risk of predation from ground predators, and 
that bats select trees of particular species and in particular stages of decay. Roost tree species selection may simply be due to tree having appropriate conditions for cavity formation (due to physiological stresses from natural forces including weather, insect attack, bacteria or fungi, and cavity-forming vertebrates) (Vonhof and Barclay 1996).

Studies directly addressing bats' selection of particular roosts are limited and new approaches for evaluating selection of roosts are needed (Brigham 2007). Forest managers need to identify general features of roosts and the surrounding habitat necessary for bats that are relevant to the manager's particular ecosystem type (Marcot 1996). Recent reports address the hypothesis that a combination of reproduction and thermoregulation needs promote differences in site selection by males and females (Brack et al. 2002). For example, female long-eared bats (Nyctophilus spp.) will continue to roost under exfoliating bark on the sunny side of trees and in shallow tree cavities (Turbill and Geiser 2008). Most evidence suggests that bats choose roost sites based on characteristics at a stand level, likely as a result of availability of potential roosts. Also, individual bats frequently change roosts and they require multiple trees during a season (Barclay and Kurta 2007).

From a management perspective, roost switching has a substantial implication that cannot be overemphasized (Barclay and Kurta 2007). In some species, groups of bats switch their roosts almost daily and use up to 100 different roosts within one year, which suggests that suitable roosts are often not severely limited (Kerth 2008). Roost switching frequency and distances moved by northern and Indiana myotis among roost trees were similar between burned and unburned stands in one study (Johnson et al. 2010). Daytime roosting is important for the energy maintenance of small, tree-roosting bats like the northern myotis (Turbill and Geiser 2003). Although frequently changing roosts, myotis bats roosted within a particular area that 
ranged in size from approximately 0.5 to 6.25 ha (Turbill and Geiser 2003). Although stand dynamics are important, managers must make recommendations that concentrate on conserving entire forested areas, because conserving specific sites alone may not always suffice (Brigham 2007).

Roost fidelity was related to the type of roost occupied in a study comparing 43 different species of bats: high fidelity was directly related to roost permanency and inversely related to roost availability (Lewis 1995). Behaviors such as dispersal, migration, and movement between alternate dens or roosts are of interest because they potentially involve costs associated with leaving a familiar area. Such movements increase the risk of predation, lower familiarity with foraging opportunities, and may disrupt social bonds (Lewis 1995). Proximity to resources may affect larger-scale selection of roosting areas by bats. By roosting close to areas with highquality foraging opportunities and sites for drinking, bats can minimize commuting times and distances, thereby reducing energy costs (Barclay and Kurta 2007). Small-scale local stand and site factors are perhaps more important than larger-scale landscape features (Broders et al. 2006). It is hypothesized that characteristics of the roost itself are more important than time and energy aspects. Distances traveled between roosts vary greatly among species, and may be related to differences in habitat within home range of various colonies (Barclay and Kurta 2007). Bats often display fidelity to a group of roosts that are clumped in the environment. This may occur in part because clumped trees tend to be similar in age, therefore similar in size. Foraging activity is high in older forests (Crampton and Barclay 1996) and often very low in sapling and regenerating stands (Buford and Lacki 1995). Reduction in numbers of large trees and snags within forests may affect roost availability and may increase the distance between sites used for roosting, foraging, and drinking (Erickson and West 1996). 
The true importance of snags and cavity trees to forest dwelling bats as night roosts, distinct from maternity sites, is not known (Ormsbee et al. 2007), but female northern myotis roost communally in summer months, presumably, to reduce thermoregulation costs (Broders et al. 2006). Compared to random trees, maternity roosts of northern myotis have been found within intact forests, signifying that these bats make extensive use of cavities and crevices in areas of low disturbance (Carter and Feldhamer 2005). Kurta et al. (1996) found that individuals that form maternity colonies collectively may use several trees to provide the total resources needed for roosting, including cover and correct temperature, during varying environmental conditions. Colonies usually have from one to a few "primary" trees or "focal" trees (O'Donnell and Sedgeley 1999) that provide proper roosting conditions most of the time. In Illinois Carter et al. (2005) found northern myotis roosted in areas with higher canopy closure than in random plots and move shorter distances between consecutive roosts ( $<100$ meters apart). In the Midwest, northern myotis commonly occur in more contiguous, interior bottomland forest habitats (Carroll et al. 2002). Menzel et al. (2001) found that all roosts located for northern myotis were located in or below the forest canopy, which suggests that solar exposure may not be as critical for selection of roost trees by maternity colonies as compared to other species of tree-roosting bats at more northern latitudes in North America.

Maternity colonies of northern myotis have been found to roost in intensively managed stands in South Carolina (Menzel et al. 2001). There, roost trees were not larger and did not extend above the surrounding forest canopy more than randomly located cavity trees; in fact, several roost trees were shorter than surrounding trees. This suggests that increased roost visibility by potential predatory species may not be of primary importance in roost tree selection (Menzel et al. 2001). Foster and Kurta (1999) hypothesized that increased maneuverability of 
northern myotis allowed that species to exploit roosts in cluttered environments to avoid niche overlap with other bat species, particularly congeneric groups. Overall, mature forests with an abundance of tree cavities seem a requisite for productive populations of northern myotis (Broders et al. 2006).

Roosts are critically important for bats because they provide cover from environmental conditions and shelter from predators, as well as locations to mate, raise young, hibernate, digest food, and socially interact (Brigham 2007). During winter, northern myotis are found in hibernacula, which are commonly caves or abandoned mines (Griffin 1940; Hitckcock 1965; Caire et al. 1979). They will return to the same hibernacula although not always in sequential seasons. Northern myotis will hibernate along with other species (M. lucifugus, Eptesicus fuscus, and Perimyotis subflavus) in hibernacula, but are usually a small portion of the total population (Caire et al. 1979). During summer, northern myotis occupy a variety of day and night roosts, and have been shown to favor tree roosts (Barbour and Davis 1969), and have also been found in anthropogenic structures (Foster and Kurta 1999); sexes roost separately, with reproductive females forming small maternity colonies of $<60$ individuals. Maternity groups roost in trees, under shingles, and in buildings (Brandon 1961; Clark et al. 1987).

Research on forest-dwelling bats has shown that the size and type of roost trees selected for roosting varies from large diameter trees in early stages of decay (Sasse and Pekins 1996) to in crevices, hollows, or under bark of live and dead deciduous trees (Foster and Kurta 1999). Structurally, roosts tend to be closer to neighboring trees than suitable roosts in randomly located cavity trees; in South Carolina, northern myotis were found to roost in nine different species of trees (Menzel et al. 2001). Tree species is an important factor that influences roost tree selection, with Robinia pseudoacacia being used significantly more than expected based on their 
abundance across the managed forest landscape (Menzel et al. 2001). In managed Allegheny hardwood - northern hardwood forests of the central Appalachians, short-lived early successional species such as black locust may provide suitable roosting habitat for northern myotis, as well as other species of bats (Johnson et al. 2009).

\section{Bat Ecology and Life History}

Bats represent about 20 percent of all classified mammalian species worldwide, with over 1,200 different bat species divided into two suborders: Megachiroptera and Michrochiroptera (Tudge 2000). In North America, 47 different species of bats can been found, represented by four groups: the leaf-nosed, ghost-faced, vesper bat, and free-tailed families (Kunz 1998). Thirteen different species of insectivorous bats can be found in the Appalachian hardwood regions alone. The genus myotis is represented by 17 different species within the North American continent, more than any other genus.

Understanding the life history and ecology contributes greatly to the protection and management of an organism. In recent years, more information on the elusive life cycle of insectivores has been uncovered. Social systems of bats are far more complex than had been previously understood (Kerth 2008). For instance, in most species of bats, females form maternity colonies to rear young communally, whereas males are solitary, form groups of their own, or join female groups. In several bat species, researchers are discovering patterns of cryptic colony and social structure in the form of fission-fusion systems (temporary splitting of colonies into several subgroups) previously known mostly from some primates, carnivores, and cetaceans (Kerth 2008).

Great variation has been observed in the mating season for bats, due mostly to factors such as migration versus hibernation, and because of the vastly different habitats they live in. 
Roosts can be divided into day and night roosts, hibernacula, summer roosts, maternity roosts, feeding roosts and transient roosts. Bats undergo periods of facultative heterothermy (during periods of hibernation), whereby they control their temperature to match surroundings (Wilson 1997). For bats that hibernate, such as the northern myotis, the vital functions (i.e. pulse rate, breathing rate, and metabolic rate) slow down dramatically.

For their size, bats are the slowest reproducing mammals (Austad et al. 1991). Copulation for many forest bats takes place in fall, when swarming behavior occurs near hibernacula for hibernating species. Hibernation exerts a profound influence on the physiology of reproductive bats. The impact of hibernation on the female reproductive cycle appears to arrest the progress of reproductive events begun in the autumn and to postpone their completion until spring. Vespertilionidae display delayed fertilization, where mating takes place and sperm is stored in fall, but fertilization and embryo implantation does not occur until spring (Oxberry 1979). The gestation period lasts $3-4$ weeks. Females of most bat species produce a single pup, but particular species give birth to twins, in June and July (Laubach et al. 1994). Young are born naked and helpless, although it has been observed that the newborns assist in their emergence and will pull themselves free before crawling to a feeding position on the mother. Young are relatively large at birth, and emerge feet first to avoid entanglement of wings. Northern myotis bats for example give birth to one young at a time, and lactation lasts on average 1-2 months (Caire et al. 1979). Male bats have been shown to play no significant role in rearing young and females care for developing young (Wilson 1997). Bat pups first exhibit spontaneous, dropevoked flapping behavior at 10 days, short horizontal flight at 17 days, and sustained flight at 24 days of age (Powers et al. 1991). During the maternity season, particularly during the lactation period, females return to their diurnal roosts several times during the night to nurse their young 
(Ormsbee et al. 2007). The earliest-born young are usually volant by early July, and the nursery colonies disband around this time (Laubach et al. 1994).

Bats have enormous potential as bioindicators: they show taxonomic stability, trends in their populations can be monitored, short- and long-term effects on populations can be measured and they are distributed widely (Jones et al. 2009). Bats provide several ecosystem services, and hence reflect the status of the plant populations on which they feed and pollinate as well as the productivity of insect communities. Bat populations are affected by a wide range of stressors that affect many other taxa. In particular, changes in bat numbers or activity can be related to climate change (including extremes of drought, heat, cold and precipitation, cyclones and sea level rise), deterioration of water quality, agricultural intensification, loss and fragmentation of forests, fatalities at wind turbines, disease, pesticide use and overhunting (Jones et al. 2009).

\section{Northern Myotis Ecology}

Within the Vespertilionidae family, the northern myotis bat (order Chiroptera, family Vespertilionidae) is a member of the myotis genus, the largest and most widely distributed group of bats in North America (Reid 2006). The word Myotis is derived from the Greek for "mouse eared". Septentrionalis comes from the Latin for "northern" (Nargosen and Brigham 1993). Other common names for this bat are northern long-eared bat and northern bat (Foster and Kurta 1999). The northern myotis is an insectivorous hibernating bat, widely distributed in Canada and eastern North America. It is commonly found in the New England states and in the southeastern United States. Its range also extends from Florida and west into Alberta, Canada, Montana, and eastern Wyoming (Kurten and Anderson 1980).

Longevity record for northern myotis, based on bats banded in the wild, is 18.5 years (Hall et al. 1957). It is this trait of longevity that separates them from other similar-sized 
mammals. In combination with natal philopatry (the behavior of remaining in or returning to location of birth), their longevity leads to an overlapping of generations that may share the same roosts, and thus to the formation of multigenerational social groups (Kerth 2008). In northern myotis, female and male bats roost separately and females form small maternity colonies (Brandon 1961). They may return to the same hibernaculum year after year, and will occupy a variety of day roosts during warmer seasons (Griffon 1940). These qualities in turn make the northern myotis a valuable indicator species.

The northern myotis is an insectivorous bat (Lacki et al. 2007) and can be found in the Fernow Experimental Forest. Previously, this myotis showed no evidence for selection of any order of insects and perhaps this species is closest to what might be considered a "foraging opportunist" (Lacki et al. 2007), but a recent prey identification study found a disproportionate number of lepidopteran prey in fecal matter, and that the northern myotis differentiates itself from other similar insectivorous bats in the prey that it selects (Dodd et al. 2012). A suite of morphological factors influences foraging behavior in insectivorous bats, including body mass, and the size and shape of the skull, jaws, and wings (Lacki et al. 2007). The importance of wingspan, wing area, and body mass for flight is widely recognized (Findley et al. 1972). For example, the size and shape of wings determine flight speed and maneuverability (Norberg 1981), which in turn, affect where a bat is likely to forage. Bats with lower wing loading exhibit greater maneuverability and are more capable of exploiting foraging space that is cluttered with vegetation (Aldridge 1986). The northern myotis has a body designed for feeding in forest canopies or near cluttered vegetation (Lacki et al. 2007).

Foraging areas are also a necessary component in the management of insectivorous bat habitat. The few estimates of foraging areas for forest dwelling bats clearly limits generalizations 
of foraging area requirements, but one commonality among studies is that foraging areas usually encompass a body of water or a riparian corridor (Waldien and Hayes 1999). Northern myotis feed on flying insects often found near bodies of water, but also glean prey from substrates (Faure et al. 1993). Gleaning allows for a broader diet, including those insects that can detect echolocation calls of aerial hawking northern myotis (Faure et al. 1993). Northern myotis have been observed using behaviors that suggest that this species is specialized for the task of gleaning prey (Ratcliffe and Dawson 2002). Northern myotis forage under the forest canopy, at small ponds or streams, along paths and roads, or at the forest edge (Caire et al. 1979; van Zyll de Jong et al. 1980; Fenton et al. 1983).

\section{Snag Density and Dynamics}

Many wildlife species require standing dead trees as part of their habitat. The ability to predict future density, distribution, and condition of snags is essential in forest management (Morrison and Raphael 1993). Most land-management agencies have established requirements for retaining a minimum number and size of snags (Morrison et al. 1986). But achieving and maintaining densities of snags is challenging because of the dynamic nature of snag recruitment (i.e. tree mortality), decay, and loss, and the desire to maximize economic return from the forest by salvaging recently dead trees (Morrison and Raphael 1993). Many eastern hardwood forests are

mainly 30 - 70-year-old second-growth stands that have received little or no management. Clearcutting is an accepted method of regenerating shade-intolerant tree species in the central Appalachians, but clear-cutting would remove, for many years, the large snags needed by some snag-dependent fauna (McComb and Muller 1983).

Under natural conditions, snags are created primarily by fire, weather, insects, and disease. Individual snags decay and fall at different rates, based on species, diameter, height, 
cause of tree death, and exposure to wind (Raphael and Morrison 1987). Most models of snag dynamics assume constant recruitment and decay and loss rates, but meeting such an assumption is unlikely because of the fluctuating nature of abiotic and biotic factors (Morrison and Raphael 1993). Previous research on snag longevity has identified tree species, tree size, decay class, crown scorch, and stand density as important factors determining snag longevity (Bull 1983; Morrison and Raphael 1993; Garber et al. 2005). The species of tree is relatively less important with regard to snag longevity than the method of creation and tree diameter (Raphael and Morrison 1987). Characteristics of individual snags and stand-level information are the most influential factors in predicting snag longevity (Russell et al. 2006). Snags in advanced stages of decay usually fall within five years and snags created by fire decay rapidly and fall quicker (within 10 years) than those on unburned plots. Snags that are larger in diameter, shorter in height, and less decayed remained standing the longest (Russell et al. 2006). Snags in large burned areas are directly exposed to wind; probably causing them to fall sooner than individual snags surrounded by live trees (Gratkowski 1956; Lohmander and Helles 1987).

Small-scale variables (age, height, DBH, tree species, decay, and snag density) are the best predictors of persistence rates (Russell et al. 2006). Age of snag was also an important variable predicting snag persistence (older snags more likely to fall). Current models of snag dynamics designed to assist land managers in maintaining wildlife habitat include the snag recruitment simulator (SRS; Marcot 1992), snag dynamics projection model (SDPM; McComb and Ohmann 1996), and Table Interpolation Program for Stand Yields (forest vegetation simulator; TIPSY; Stone 1996). The models rely on information regarding snag longevity to estimate how land management practices will affect the availability of snags for wildlife (Garber et al. 2005). Developing snag longevity models based on larger-scale, remotely sensed data will 
be necessary to provide more easily implemented management guidelines for maintaining wildlife habitat in postfire forests (Russell et al. 2006).

\section{LITERATURE CITED}

Abrams, M. 1992. Fire and the development of oak forests. Bioscience 42(5): 346-354.

Albrecht, M. A., B. C. McCarthy. 2006. Effects of prescribed fire and thinning on tree recruitment patterns in central hardwood forests. Forest Ecology and Management 226: $88-103$.

Aldridge, H.D.J.N. 1986. Maneuverability and ecological segregation in the little brown bat (Myotis lucifugus) and Yuma (M. yumanensis) bat (Chiroptera: Vespertilionidae). Canadian Journal of Zoology 64: 1878-1882.

Aldridge, H. D., I. L. Rautenbauch. 1987. Morphology, echolocation and resource partitioning in insectivorous bats. Journal of Animal Ecology 56: 763-778.

Arnett, E.B., 2003. Advancing science and partnerships for the conservation of bats and their habitats. Wildlife Society Bulletin 31: 2-5.

Austad, S.N., K.E. Fischer. 1991. Mammalian aging, metabolism, and ecology: Evidence from the bats and marsupials. Journal of Gerontology 46: B47-B55

Baker, James B., Cain, Michael D., Guldin, James, M., Murphy, Paul A., Shelton, Michael G. 1996. Uneven-aged silviculture for the loblolly and shortleaf pine cover types. U.S. For. Serv. Gen. Tech. Rpt. SO-118. 63 p. Southern Research Station. Asheville, North Carolina.

Barbour, R. W., W. H. Davis. 1969. Bats of America. University Press of Kentucky, Lexington. Berger, A. L., S. A. Della Pietra, and V. J. Della Pietra. 1996. A maximum entropy approach to natural language processing. Computational Linguistics, 22(1): 39-71. 
Boyles, J. G., D. P. Aubrey. 2005. Managing forests with prescribed fire: implications for a cavity-dwelling bat species. Forest Ecology and Management 222: 108-115

Brack, V., Jr., C. W. Stihler, R. J. Reynolds, C. M. Butchkoski, C. S. Hobson. 2002. Effect of climate and elevation on distribution and abundance in the mid-eastern states. The Indiana bat: biology and management of an endangered species. Bat Conservation International, Austin, Texas.

Broders, H. G., G. J. Forbes, S. Woodley, I. D. Thompson. 2006. Range extent and stand selection for roosting and foraging in forest-dwelling northern long-eared bats and little brown bats in the greater fundy ecosystem, New Brunswick. Journal of Wildlife Management. 70(5): 1174-1184.

Brooks, R. T., W. M. Ford. 2006. Introduction to the special section - bat habitat use in eastern North America temperate forests: site, stand, and landscape effects. Journal of Wildlife Management 70: 1171-1173.

Brose, P. D., D. VanLear, R. Cooper. 1999. Using shelterwood harvests and prescribed fire to regenerate oak stands on productive upland sites. Forest Ecology and Management 113: $125-141$.

Buford, L. S., M. J. Lacki. 1995. Habitat use by Corynorhinus townsendii virginianus in the Daniel Boone National Forest. American Midland Naturalist 134: 340-345.

Bull, E.L. 1983. Longevity of snags and their use by woodpeckers. Pages 64-67 in J. W. Davis, G. A. Goodwin, and R. A. Ockenfels, Tech. Coords. Snag Habitat Management: Proceedings of a Symposium. USDA For. Serv. Gen. Tech. Rep. RM-99. 226 pp.

Burnham, K. P., D.R. Anderson. 2002. Model Selection and multimodel inference: a practical information theoretical approach, $2^{\text {nd }}$ edition. Springer, New York, New York. 
Carroll, S. K., T. C. Carter, G.A. Feldhammer. 2002. Placements of nets for bats: Effects on perceived fauna. Southeastern Naturalist 1: 193-198.

Carter, T. C. 2006. Indiana bats in the Midwest: the importance of hydric habitats. Journal of Wildlife Management 70: 1185-1190.

Carter, T. C., G. A. Feldhamer. 2005. Roost tree use by maternity colonies of Myotis sodalis and M. septentrionalis in southern Illinois. Journal of Forest Ecology and Management 219: 259-268.

Clark, D. R. Jr. 1988. Environmental contamination and management of bat populations in the United States. Pp. 409-413 in Management of Amphibians, Reptiles and small mammals in North America: proceedings of the symposium, July 19-21, 1988, Flagstaff, Arizona.

Clark, F. B. 1993. An historical perspective of oak regeneration. Pages 3-13 In D. Loftis, and C. E. McGee, editors. Proceedings, Oak regeneration: serious problems, practical recommendations; 1992 September 8-10; Knoxville, Tennessee. General Technical Report SE-84. USDA Forest Service, Southern Research Station, Asheville, North Carolina.

Clawson, R. L. 2002. Trends in population size and current status. Pages 2-8 In A. Kurta and J. Kennedy, editors. The Indiana bat: biology and management of an endangered species. Bat Conservation International, Austin, Texas.

Crampton, L. H., R. M. R. Barclay. 1996. Habitat selection by bats in fragmented and unfragmented aspen mixedwood stands of different ages. Pp. 238-259. Bats and forests symposium (R. M. R. Barclay and R. M. Brigham, eds.). British Columbia Ministry of Forests, Victoria, Canada. 
Dodd, L. E., E. G. Chapman, J. D. Harwood, M. J. Lacki, L. K. Rieske. 2012. Identification of prey of Myotis septentrionalis using DNA-based techniques. Journal of Mammalogy 93(4): 1119-1128.

Erickson, J. L., S. D. West. 1996. Managed forests in the western cascades: the effects of seral stage on bat habitat use patterns. Bats and forests symposium (R. M. R. Barclay and R. M. Brigham, eds.). British Columbia Ministry of Forests, British Columbia, Canada.

Fenton, M. B. 1997. Science and the conservation of bats. Journal of Mammalogy 78: 1-14.

Fenton, M. B. 2003. Science and the conservation of bats: where to next? Wildlife Society Bulletin 31: 6-15.

Findley, J.S., E.H. Studier, D.E. Wilson. 1972. Morphological properties of batwings. Journal of Mammaology 53: 329-444.

Fogel, R., M. Ogawa, J. M. Trappe. 1973. Terrestrial decomposition: a synopsis. ConiferousForest Biome Report 135. University of Washington, Seattle. 12 pp.

Ford, W. M., M. A. Menzel, J. L. Rodrigue, J. M. Menzel, J. B. Johnson. 2005. Relating bat species presence to simple habitat measures in a central Appalachian forest. Biological Conservation 126: 528-539.

Foster, R.W., A. Kurta. 1999. Roosting ecology of the Northern Bat (Myotis septentrionalis) and comparisons with the endangered Indiana Bat (Myotis sodalis). Journal of Mammalogy 80(2): 659-672.

Garber, S. M., J. P. Brown, D. S. Wilson, D. A. Maguire, L. S. Heath. 2005. Snag longevity under alternative silvicultural regimes in mixed-species forests of central Maine. Canadian Journal of Forest Research 35: 787-796. 
Gratkowski, H. J. 1956. Windthrow around staggered set- tings in old-growth Douglas-fir. Forest Science 2: 60-74.

Guldin, J. M., W. H. Emmingham, S. A. Carter, D. A. Saugey. 2007. Silvicultural practices and management of habitat for bats. Pages 177-205 In M. J. Lacki, J. P. Hayes, and A. Kurta, editors. Bat in Forests. Johns Hopkins University Press, Baltimore, Maryland.

Hallett, J. G., T. Lopez, M. A. O’Connell, M. A. Borysewicz. 2001. Decay dynamics and avian use of artificially created snags. Northwest Science 75: 378-386.

Harvey, M. J., J. S. Altenbach, T. L. Best. 1999. Bats of the United States. Arkansas Game and Fish Commission and U. S. Fish and Wildlife Service, Little Rock, Arkansas.

Hayes, J. P., S. C. Loeb. 2007. The influences of forest management on bats in North America. Pp. 207-235 in Bats in forests: conservation and management (M. J. Lacki, J. P. Hayes, and A. Kurta, eds.). Johns Hopkins University Press, Baltimore, Maryland.

Hicks, R. R. 1998. Ecology and management of central hardwood forests. John Wiley \& Sons, Inc.. New York, NY.

Hill, J. E., J. D. Smith. 1984. Bats: a natural history. University of Texas Press. Austin.

Hodgkison, R., S. T. Balding, A. Zubaid, T. H. Kunz. 2004. Habitat structure, wing morphology, and the vertical stratification of Malaysian fruit bats (Megachiroptera: Pteropodidae). Journal of Tropical Ecology 20: 667-673.

Horton, S. P.; Mannan, R. W. 1988. Effects of prescribed fire on snags and cavity-nesting birds in southeastern Arizona pine forests. Wildlife Society Bulletin 16:3744. Hutto, R. L. 1995.

Humes, M. L., J. P. Hayes, M. W. Collopy. 1999. Bat activity in thinned, unthinned, and oldgrowth forests in western Oregon. Journal of Wildlife Management 63(2):553-561. 
Hunter, M. L. 1990. Wildlife, Forests, and Forestry: Principles of Managing Forests for Biological Diversity. Prentice Hall, Englewood Cliffs, NJ. 370 p.

Johnson, J. B., J. W. Edwards, W. M. Ford, J. E. Gates. 2009. Roost tree selection by northern myotis (Myotis septentrionalis) maternity colonies following prescribed fire in a central Appalachian hardwood forest. Forest Ecology and Management 258: 233-242.

Johnson, J. B., W. M. Ford, J. L. Rodrigue, C. M. Johnson. 2010. Roost selection by male Indiana myotis following forest fires in central Appalachian hardwood forests. Journal of Fish and Wildlife Management 15: 39-48.

Jones, G., D. S. Jacobs, T. H. Kunz, M. R. Willig, P. A. Racey. 2009. Carpe noctem: the importance of bats as bioindicators. Endangered Species Research 8: 93-115.

Kerth, G. 2008. Causes and consequences of sociality in bats. BioScience 58:737-746.

Kochenderfer, J. N. 2006. Fernow and the Appalachian hardwood region. Pages 17-39 In M. B. Adams, D. R. DeWalle, and J. L. Horn, editors. The Fernow watershed acidification study. Springer, Dordrecht, Netherlands. 279 pp.

Kochenderfer, J. N., M. B. Adams, G. W. Miller, J. D. Helvey. 2007. Factors affecting large peakflows on Appalachian watersheds: lessons from the Fernow Experimental Forest. USDA Forest Service, Research Paper NRS-3, Northeastern Research Station, Newtown Square, PA, 24 pp.

Kurta, A., K.J. Williams, R. Mies. 1996. Ecological, behavioural, and thermal observations of a peripheral population of Indiana bats (Myotis sodalis). Pp. 102-117, In R.M.R. Barclay and R.M. Brigham (Eds.). Bats and Forest Symposium. British Columbia Ministry of Forests, Victoria, BC, Canada. 292 pp. 
Kunz, T. A., P. A. Racey. 1998. Bat Biology \& Conservation. Smithsonian Institution Press. Washington , D.C.

Kurten, B., E. Anderson. 1980. Pleistocene mammals of North America. Columbia University Press, New York.

Lacki, M. J., J. S. Johnson, L. E. Dodd, M. D. Baker. 2007. Prey consumption of insectivorous bats in coniferous forests of north-central Idaho. Northwest Science 3: 199-205.

Laubach, C.M., Bowles, J.B. Laubach, R. 1994. A Guide to the Bats of Iowa: Des Moines, Iowa, Iowa Department of Natural Resources, Nongame Technical Series No. 2, 18 p.

Leput, D. W. 2004. Eastern red bat (Lasiurus borealis) and eastern pipistrelle (Pipistrellus subflavus) maternal roost selection: implications for forest management. M.S. Thesis. Clemson University, Clemson, South Carolina.

Lewis, S. E. 1995. Roost fidelity in bats: a review. Journal of Mammalogy 76: 481-496.

Loeb, S. C., T. A. Waldrop. 2008. Bat activity in relation to fire and fire surrogate treatments in southern pine stands. Forest Ecology and Management 255: 3185-3192.

Lohmander, P., F. Helles. 1987. Windthrow probability as a function of stand characteristics and shelter. Scandi- navian Journal of Forest Research 2: 227-238.

Madarish, D.M., J. L. Rodrigue, M. B. Adams. 2002. Vascular flora and macroscopic fauna on the Fernow Experimental Forest. USDA Forest Service, General Technical Report GTRNE-291, Northeastern Research Station, Newtown Square, PA.

Marcot, B.G., 1996. An ecosystem context for bat management: a case study of the Interior Columbia River Basin, USA. In: Barclay, R.M.R., Brigham, R.M. (Eds.), Proceedings of the Bats and Forests Symposium. BC Ministry of Forests Working Paper No. 23: $19-36$. 
Marcot, B. G. Snag recruitment simulator, Rel. 3.1 [Computer program]. 1992. Portland, OR: Pacific Northwest Research Station, Forest Service, U.S. Department of Agriculture. Available from: Pacific Northwest Research Station. P.O. Box 3890, Portland, OR 97208.

Martin, K. W., D. M. Leslie, Jr., M. E. Payton, W. L. Puckette, S. L. Hensley. 2003. Internal cave gating for protection of colonies of the endangered gray bat (Myotis grisescens). Acta Chiropterologica 5: 151-160.

Maser, C., R.G. Anderson, K. Cromack Jr., J.T. Williams, R.E. Martin. 1979. Dead and down woody material. In J.W. Thomas (technical editor). Wildlife habitats in managed forests: the Blue Mountains of Oregon and Washington. USDA Forest Service Agricultural Handbook No. 553. pp.78-95.

McClelland, B. R., S. S. Frissel, W. C. Fischer, C. H. Halvorson. 1979. Habitat management for hole-nesting birds in forests of western larch and Douglas fir. Journal of Forestry 77: $180-483$.

McComb, W. C., R. N. Muller. 1983. Snag densities in old-growth and second-growth Appalachian Forests. The Journal of Wildlife Management 47(2): 376-382.

McComb, William, C. Ohmann, L. Janet. Snag Dynamics Projection Model [Computer program]. 1996. Corvallis, OR: Pacific Northwest Research Station, Forest Service, U.S. Department of Agriculture. Available from: Pacific Northwest Research Station. 3200 SW Jefferson Way, Corvallis, OR 97331.

Menzel, M.A., Carter, T.C., Ford, W.M., Chapman, B.R. 2001. Tree-roost characteristics of subadult and female adult evening bats (Nycticeius humeralis) in the upper Coastal Plain of South Carolina. American Midland Naturalist 145: 112-119. 
Menzel, M. A., S. F. Owen, W. M. Ford, J. W. Edwards, P. B. Wood, B. R. Chapman, K. V. Miller. 2002. Roost tree selection by northern long-eared bat (Myotis septentrionalis) maternity colonies in an industrial forest of the central Appalachian Mountains. Forest Ecology and Management 155: 107-114.

Miller, J. H. 1993. Oak plantation using mechanical, burning, and herbicide treatments. Pages 264-289 In D. Loftis, and C. E. McGee, editors. Proceedings, Oak regeneration: serious problems, practical recommendations; 1992 September 8-10; Knoxville, Tennessee. General Technical Report SE-84. USDA Forest Service, Southern Research Station, Asheville, North Carolina.

Morrison, M. L., M. G. Raphael. 1993. Modeling the dynamics of snags. Ecological Applications 3(2): 322-330.

Morrison, M. L., M. F. Dedon, M. G. Raphael, M. P. Yoder-Williams. 1986. Snag requirements of cavity-nesting birds: are USDA Forest Service guidelines being met? Western Journal of Applied Forestry 1: 3840.

Norberg, U.M. 1981. Flight morphology and the ecological niche. Symposia of the Zoological Society of London 48:173-197.

Nowacki, G. J., M. D. Abrams. 2008. The demise of fire and "mesophication" of forests in the eastern United States. BioScience 58: 123-138.

Ormsbee, P. C., J. D. Kiser, S. I. Perlmeter. 2007. Importance of night roosts to the ecology of bats. Pp.129-151, in Bats in forests: conservation and management (M. Lacki, J. Hayes, and A. Kurta, eds.). The Johns Hopkins University Press, Baltimore, 329 pp.

Owen, S. F., M. A. Menzel, W. M. Ford, J. W. Edwards, J. M. Menzel, B. R. Chapman, P. B. Wood, K. V. Miller. 2004. Bat activity in harvested and intact forest stands in the 
Allegheny Mountains. Northern Journal of Applied Forestry 21: 154-59.

Oxberry, B. A. 1979. Female reproductive patterns in hibernating bats. Reproduction: Journal of the Society for Reproduction \& Fertility 56: 359-367.

Patriquin, K. J., R. M. Barclay. 2003. Foraging by bats in cleared, thinned and unharvested boreal forest. Journal of Applied Ecology 4: 646-657.

Pierson, E. D. 1998. Tall trees, deep holes, and scarred landscapes; conservation biology of North American bats. Pages 309-325 In T. H. Kunz and P. A. Racey, editors. Bat biology and conservation. Smithsonian Institution Press, Washington, D.C.

Potter, B.E., J. A. Andresen. 2002. A finite difference model of temperatures and heat flow within a tree stem. Canadian Journal of Forest Research 32: 548-555.

Powers, L. V., Kandarian, S. C. \& Kunz, T. H. 1991.Ontogeny of flight in the little brown bat, Myotis lucifugus: Behaviour, morphology, and muscle histochemistry. Journal of Comprehensive Physiology (A) 168: 675-685.

Raphael, M. G. M. L. Morrison. 1987. Decay and dynamics of snags in the Sierra Nevada, California. For Sci. 33: 774-783.

Ratcliffe, J. M., J. W. Dawson. 2002. Behavioural flexibility: the little brown bat, myotis lucifugus, and the northern long-eared bat, $m$. septentrionalis, both glean and hawk prey. University of Toronto at Mississuaga. Elsevier Ltd.

Reid, F. A. 2006. Peterson's field guide to mammals of North America north of Mexico. Houghton Mifflin Company. New York.

Russell, R. E., V. A. Saab, J. G. Dudley, J. J. Rotella. 2006. Snag longevity in relation to wildfire and postfire salvage logging. Forest Ecology and Management 232: 179-187. 
Saab, V., Brannon, R., Dudley, J., Donohoo, L., Vanderzanden, D., Johnson, B., Lackowski, H., 2002. Selection of fire-created snags at two spatial scales by cavity-nesting birds. USDA Forest Service General Technical Report PSW-GTR-181, Portland, Oregon, USA.

Saab, V. A., R. E. Russell, J. G. Dudley. 2004. Nest densities of cavity-nesting birds in relation to postfire salvage logging and time since wildfire. The Condor 109: 97-108.

Sasse, D.B., Pekins, P.J. 1996. Summer roosting ecology of northern long-eared bats (Myotis septentrionalis) in the White Mountain National Forest. In:Barclay, R.M.R., Brigham, R.M. (Eds.), Bats and Forests Symposium., British Columbia Ministry of Forests, Victoria, BC, Canada, pp. 91-101.

Schuler, T. M., M. A. Fajvan. 1999. Understory tree characteristics and disturbance history of a central Appalachian forest prior to old-growth harvesting. USDA Forest Service, Res. Pap. NE-710, Northeastern Research Station, Radnor, PA.

Schuler, T. M. 2004. Fifty years of partial harvesting in a mixed mesophytic forest: composition and productivity. Canadian Journal of Forest Research 34: 985-997.

Schuler, T. M., M. B. Adams, M. Gundy. 2005. Prescribed burning and variable intensity overstory mortaility for enhanced wildlife habitat structure and long-term oak restoration. USDA Forest Service Study 4300-FS-NRS01.

Sedgeley, J. A. 2001. Quality of cavity microclimate as a factor influencing selection of maternity roosts by a tree-dwelling bat, Chalinolobus tuberculatus, in New Zealand. Journal of Applied Ecology 38: 425-438.

Sedgeley, J. A., C. F. J. O’Donnell. 1999b. Roost selection by long-tailed bat, Chalinolobus tuberculatus, in temperate New Zealand rainforest and implications for the conservation of bats in managed forest. Biological Conservation 88: 261-276. 
Smith, K. T., E. K. Sutherland. 1999. Fire-scar formation and compartmentalization in oak. Canadian Journal of Forest Research 29: 166-171.

Stone, J. 1996. TIPSY (Table Interpolation Program for Stand Yields). B.C. Ministry of Forests, Research Branch, PO Box 9519 Stn. Prov. Gov., Victoria BC V8W 9C2 Canada. URL: http://www.for.gov.bc.ca/research/gymodels/Tipsy/.

Thomas, Jack W., R. G. Anderson, C. Maser, E. L. Bull. 1979. Snags. p. 60-77. Wildlife habitats in managed forests the Blue Mountains of Oregon and Washington, USDA Forest Service. Ag. Hand. No. 55: 512.

Tudge, C. 2000. The Variety of Life. Oxford University Press.

Turbill, C., Geiser, F. 2008. Hibernation by tree-roosting bats. Journal of Comparative Physiology 178(5): 597-605.

Tuttle, M. D. 1979. Status, causes of decline, and management of endangered gray bats. Journal of Wildlife Management 43(1): 1-17.

USDA Forest Service. 2002. Forest inventory and analysis national core field guide, Vol. 1: Field data collection procedures for phase 2 plots. Vers. I .6. Internal rep. on file with USDA For. Serv., FIA, Washington, DC.

Vonhof, M. J., R. M. R. Barclay. 1996. Roost-site selection and roosting ecology of forestdwelling bats in southern British Columbia. Canadian Journal of Zoology 74: 17971805.

Waldien, D. L., J. P. Hayes. 1999. Acitivity areas of female long-eared myotis in coniferous forests in western Oregon. Oregon State University, Corvalis, OR.

Wilson, D. E. 1997. Bats in Question: The Smithsonian Answer Book. Smithsonian Institution Press. Washington, D.C.. 


\section{CHAPTER 2}

ROOST TREE USE OF NORTHERN MYOTIS (Myotis septentrionalis) IN A CENTRAL APPALACHIAN HARDWOOD FOREST 
July 2013

Milu Karp

West Virginia University

322 Percival Hall

Morgantown, WV 26506

415/717-9982

milukarp@gmail.com

ROOST TREE USE OF NORTHERN MYOTIS (Myotis septentrionalis) IN A CENTRAL APPALACHIAN HARDWOOD FOREST

MILU S. KARP, Division of Forestry and Natural Resources, West Virginia University, Morgantown, WV 26505

\section{ABSTRACT}

Recent declines in myotis populations throughout the mid-Atlantic region due to habitat degradation and the spread of white-nose syndrome have led to the increased need for understanding of roost ecology to aid in population recovery. Land management agencies in the Central Appalachian Hardwood Region can contribute to the conservation and possible recovery of northern myotis through habitat creation by means of prescribed fire. Within the Fernow Experimental Forest in West Virginia, three separate compartments were subjected to prescribed fire to better understand the effects of disturbance on summer roost tree use. Female and male northern myotis were captured during 11 nights, attached with radio transmitters and located during daylight hours using radio telemetry. During the summer 2011 and 2012, 38 northern myotis roost trees were located in burned areas and unburned areas. Measurements were taken on the individual roost tree and the area surrounding each roost tree, including species, size, canopy gap, distance to neighboring trees, aspect and slope at roost tree locations. Black locust was the most utilized tree species ( $21 \%$ of roosts), followed by red maple and red oak. Roosts 
were located in trees with cavities, loose bark, and crevices; $57 \%$ of female and $40 \%$ of male roosts were in snags. Both female and male northern myotis were found roosting in burned and unburned areas. Female roost trees were surrounded by smaller neighboring trees further in decay and lower in crown class than trees used by male bats. Female northern myotis also used roosts surrounded with larger overhead gaps in the canopy than male northern myotis roost trees. Males roosted on less steep slopes than females. Roosts trees of both female and male northern myotis in burned areas were surrounded by trees further in decay and higher in crown class. Roosts in burned areas had a greater canopy gap and were located on steeper slopes. Slope at roost locations was significant in both female and male roost selection and well as for roosts in burned areas and unburned areas, as was the amount of gap present in the canopy surrounding roost trees. Northern myotis exploited areas treated with prescribed fire, but were found using roost trees in both burned and unburned areas. As the burned compartments within the FEF continue to decay and forest regeneration is allowed to progress, the effect of fire disturbance on roosting ecology can be better quantified and allow forest managers to develop models for roost tree creation and use on a local and landscape scale.

KEY WORDS: Northern myotis, prescribed fire, roost selection, West Virginia

\section{INTRODUCTION}

In recent decades attention has been given to the management and conservation of forestdwelling bats to promote the recovery of declining populations (Tuttle 1979; Fenton 2003). This focus is due to their important ecological roles as nocturnal insectivores and as a possible indicator species of forest ecosystem health (Fenton 2003). Myotid bats have suffered substantial declines and represent the largest and most widely distributed group of bats in North America (Reid 2006). Human disturbance of hibernacula, environmental pollution, and loss of summer 
habitat (Tuttle 1979, Pierson 1998, Fenton 2003) have led to population declines, resulting in the listing of species under the Endangered Species Act (Title 16 United States Code, Sections 15311544), as well as listing as species of concern (Harvey et al. 1999). Recent declines in myotis populations throughout the mid-Atlantic region due to habitat degradation and the spread of white-nose syndrome (WNS) (Geomyces destructans) have led to the increased need for understanding of roost ecology (winter hibernacula and summer roost trees) to aid in population recovery.

The northern myotis (Myotis septentrionalis) is a small (5-10 g) forest-dwelling bat found throughout much of the eastern United States (Barbour and Davis 1969; Caceres and Barclay 2000; Ford et al. 2005). Northern myotis were once common in Central Hardwood Forests and their recent decline associated with WNS support a need to examine their roost site ecology. Northern myotis roost in trees in various stages of decay and size class (Lacki et al. 2001). They roost under exfoliating bark or in crevices or cavities of live and dead or dying trees (Campbell et al. 1996, Brigham et al. 1997, Weller and Zabel 2001, Menzel et al. 2002). Northern myotis use a variety of tree species for roosts including pin oak (Quercus palustris), and elm (Ulmus spp.) in southern Illinois (Carter et al. 2005) and short-leaf pine (Pinus echinata) and sourwood (Oxydendron arobreum) in northeastern Kentucky (Lacki et al. 2001). In the Central Appalachian region of West Virginia, northern myotis select black locust (Robinia pseudoacacia) in greater proportion than available (Menzel et al. 2002; Johnson et al. 2009). Black locust is a highly decay resistant species (Panshin et al. 1964; Menzel et al. 2002) that can develop cavities and other suitable roost characteristics as a persistent snag (Lewis 1995, Menzel et al. 2002, Owen et al. 2002, Ford et al. 2006, Johnson et al. 2009). 
Male northern myotis are less selective than females regarding roost tree characteristics (Perry et al. 2007). Perry et al. (2007) compared roost selection between female and male northern myotis in central Arkansas (Perry et al. 2007) and found fewer large hardwoods and small snags surrounding female roost sites than at random sites. Male roost sites were more common in unharvested stands than female roost sites while female roosts had fewer surrounding midstory trees than male northern myotis sites (Perry et al. 2007). Female northern myotis form maternity colonies of <100 individuals in cavities and under bark (Sasse and Pekins 1996; Foster and Kurta 1999; Menzel et al. 2002). These sites provide shelter during lactation and rearing of young, as well as predator avoidance and support of thermoregulation (Hamilton and Barclay 1994; Willis et al. 2006). In the central Appalachian Mountains and in southern Illinois, northern myotis maternity colonies were found in roost trees within intact forests (Carter et al. 2005). Alternately, in West Virginia, Johnson et al. (2009) found northern myotis maternity colonies readily exploiting areas where prescribed fire had created large canopy gaps.

Prescribed fire is beneficial in regulating and maintaining forest ecosystems of the eastern United States (Boyles and Aubrey 2006). Fire assists in the regeneration of some hardwood species (Clark 1993). The lack of regeneration and retention of oaks and hickories (Carya spp.) in hardwood forests remains a concern for both wildlife and forest managers. This inadequacy is partly attributed to the suppression of fire and uneven-aged management practices that have allowed shade-tolerant species such as maples (Acer spp.) and beech (Fagus spp.) to dominant the landscape (Clark 1993; Schuler and Fajvan 1999; Brose et al. 2001; Schuler 2004). Oaks (Quercus spp.) are valuable tree species for wildlife, including bats. Acorn production by oaks is an important food resource for wildlife in many deciduous forests (McShea et al. 2010) and many species of forest dwelling bats including northern myotis have been found roosting in oak 
trees (Menzel et al. 2002; Lacki et al. 2009; Johnson et al. 2009). Alterations to forest structure that reduces competition between oaks and more shade tolerant species and increases forest canopy gap size can aid in oak retention and regeneration (Miller, 1993; Brose et al. 2001; Johnson et al. 2009). Such alterations to forest structure could lead to an increase in snag abundance that may also serve to provide additional roosting habitat for northern myotis (Johnson et al. 2009). In the Central Hardwood Region, prescribed fire has been used to aid in oak regeneration and retention (Miller 1993; Brose et al. 2001), but little is known about the impact of fire on the modification of northern myotis roosting habitat. It is suggested that maternity roost trees (Lacki et al. 2001) may be selected in areas where longer periods of solar radiation exist, such as those found under gaps in the canopy created by fire disturbance. Whether recruitment and survivorship of female and male bats is improved through changes to forest stands remains to be determined (Johnson et al. 2009); however, the implementation of silvicultural practices such as prescribed fire may help to sustain a variety of tree species, tree size classes, and snag decay stages necessary to sustain populations of northern myotis (Lacki et al. 2001). For example, fire can accelerate the creation of snags and increase the size of existing canopy gaps or create new gaps (Johnson et al. 2009) as well as increase insect abundance (Lacki et al. 2009). As managers attempt to improve oak regeneration through the use of prescribed fire, bat habitat may also be enhanced through the creation of suitable roosts (Boyles and Aubrey 2006; Keyser and Ford 2006; Johnson et al. 2009).

Consequently, I examined (1) differences in roost sites of northern myotis in forested stands subjected to prescribed fire (hereafter, burned) and in unburned forested stands, and (2) compared roost site use between female and male northern myotis in burned and unburned stands. I hypothesized that prescribed fire would increase the availability of potential roost sites 
resulting from dead and dying trees, and therefore predicted that northern myotis roosts would be found more often in stands subjected to prescribed fire. Moreover, I hypothesized that an increase in tree mortality in burned areas would result in the creation of canopy gaps and associated increase in solar exposure. I predicted that roosts of female northern myotis would be found more often in burned areas because of beneficial thermal conditions due to larger gaps in the canopy.

\section{METHODS}

\section{Study Area}

Research was conducted on the Fernow Experimental Forest (FEF) $\left(39.03^{\circ} \mathrm{N}, 79.67^{\circ} \mathrm{S}\right)$ located $^{\circ}$ in Tucker County, West Virginia. The FEF is managed by the United States Forest Service, Northern Research Station. It is located in the central Appalachians approximately $5 \mathrm{~km}$ south of Parsons, West Virginia, in the Unglaciated Allegheny Plateau Region subsection of the Appalachian Highlands Physiographic Province (Fenneman 1938; Kochenderfer et al. 2007). The FEF was established in 1934 following the designation of the Elklick Run watershed for research and demonstration of forestry practices. When established, the FEF comprised 1470 ha; it was expanded to about 1900 ha in 1974 (U.S. Forest Service Experimental Forest and Range Network). Elevation on the FEF ranges of 530 to 1115 m, with Elklick stream running approximately south to north through the forest. Several tributaries intersect Elklick Run, creating over $5.5 \mathrm{~km}$ of streams (Madarish et al. 2002). Mean annual precipitation is estimated at $145.8 \mathrm{~cm}$ per year and the mean annual temperature is $9.2^{\circ} \mathrm{C}$ (Kochenderfer 2006).

The FEF vegetation consists of second- and third-growth hardwood stands. The secondgrowth forest is classified as mixed mesophytic, having characteristics of both mixed-oak and northern hardwood forest types (U.S. Forest Service Experimental Forest and Range Network). Vegetation on the FEF has been managed by even (patch clear-cut) and uneven-aged (e.g., 
single-tree selection), along with two-age and other partial harvesting and silvicultural practices since the mid- $20^{\text {th }}$ century, or left undisturbed following initial harvesting in the Elklick watershed from 1903 to 1911 (Schuler and Fajvan 1999). This combination has created a rich mosaic of stand structures. This ecoregion is dominated by mixed mesophytic vegetation; it is identified as a mixed mesophytic forest type (Hicks 1998). Tree species dominating the FEF include: sugar maple (Acer saccharum), red maple (A. rubrum), yellow-poplar (Liriodendron tulipifera), American beech (Fagus grandifolia), sweet birch (Betula lenta), black cherry (Prunus serotina), and basswood (Tilia americana) (Schuler 2004).

Bat species found in the FEF include northern myotis, little brown bat (Myotis lucifugus), big brown bat (Eptesicus fuscus), tri-colored bat (Pipistrellus subflavus), eastern red bat (Lasiurus borealis), silver-haired bat (Lasionycteris noctivagans), and hoary bat (Lasiurus cinereus), all of which can be found from late spring to late fall (Owen et al. 2004). The federally listed Indiana bat (Myotis sodalis) has also been identified in the FEF, and utilizes Big Springs cave during winter months for hibernation (Ford et al. 2005) along with northern myotis. Big Springs Cave, located within the FEF, is part of an extensive cave system underlying or within the Greenbrier limestone formation.

Recently, prescribed fire has been utilized to encourage oak regeneration in areas where clear-cutting and fire have both been underutilized and suppressed (Schuler 2004). In April and May of 2007, three compartments were treated with prescribed fire for 1 day using a strip-head fire technique to understand the effects of fire on regeneration and habitat enhancement. A prescribed fire treatment was applied to $152 \mathrm{ha}$, consisting of compartment 45 (127 ha), 13 (13 ha) and 21 (12 ha). All 3 compartments were retreated with fire in a following year (compartments 13 and 21 in 2008; compartment 45 in 2009) (Appendix 2.a). 


\section{Bat capture and radio telemetry}

Bat capturing. - Bats were captured between May and September 2011 and 2012 using mist nets (Avinet, Inc., Dryden, NY), erected in various locations over and near small bodies of water (springs, streams, and artificial weir ponds). A single harp trap was placed at the entrance of Big Springs Cave. Locations for netting were chosen in an attempt to sample in both burned and unburned areas (as well as near cave entrances in an attempt to capture northern myotis). Nets were set up $<2$ hours after sunset, in suitable weather as to avoid rain and wind. Specific data collected for each bat captured followed Menzel et al. (2002) and included: species, sex, age, forearm length, weight and reproductive condition (if possible) (Menzel et al. 2002).

Radio-telemetry. - Following capture and weighing, I attached radio transmitters (Lotek

Wireless Inc, Newmarket, Ontario, Canada) between the scapulae of adult northern myotis, after trimming fur to expose skin. I used skin bond glue (SkinBond®, Smith \& Nephew Inc., Largo, FL) to attach the 0.35 gram radio transmitters. Capture and handling of bats followed established guidelines of the American Society of Mammalogists (ACUC, 1998). The estimated battery life of transmitters was 12 - 15 days. I used radio receivers and 3-element Yagi antennae to locate bats (Wildlife Materials, Inc., Murphysboro, Illinois). I tracked individuals and located diurnal roosts for the length of transmitter battery life or until transmitters fell off. I used a Garmin GPSmap 60CSx global positioning units to document each roost tree location.

\section{Habitat and Vegetation Measurements}

Roost trees. - I recorded the following characteristics of each individual roost tree: species, dbh $(\mathrm{cm})(\mathrm{DBHR})$, decay class $(\mathrm{DECAYR})(1=$ live, $2=$ declining, $3=$ recent dead, $4=$ loose bark, $5=$ no bark, $6=$ broken top, $7=$ broken bole, $8=$ down material, $9=$ stump; Maser et al. 1979), crown class (CROWNR) $(4=$ suppressed, $3=$ intermediate, $2=$ co-dominant, $1=$ 
dominant; USDA Forest Service 2002), tree height (m) (HEIGHT), and ocular estimate of remaining bark (BARK; 0, 25, 50, 75, 100\%; Lacki et al. 2001; Carter et al. 2005; Perry et al. 2007; Johnson et al. 2009; Lacki et al. 2009). I recorded percent slope (SLOPE) and degree aspect (ASPECT) at the base of each roost tree using a compass. I determined canopy coverage at each roost tree using photographs taken with a Nikon Coolpix 8400 camera with fish-eye lens (Melville, New York) attached to a self-leveling tripod. I placed the camera on the east side of the roost tree, with top of camera pointed north and lens directed up with camera horizontal to ground level. I used Winscanopy and XLS canopy software (Regent Instruments, Inc., Canada) to determine percent canopy coverage on 4 levels: percent canopy gap as whole (TOTALGAP), $45^{\circ}$ wedge off of the horizon (HORIZGAP), $90^{\circ}$ wedge centered on midpoint (OVERHEADGAP), and a $90^{\circ}$ wedge centered on the four cardinal directions (NORTHGAP, EASTGAP, SOUTHGAP, WESTGAP). Basal area surrounding the roost tree was measured with a 20 -factor prism $\left(\mathrm{m}^{2} / \mathrm{ha}\right.$; BASAL), using the roost tree as plot center. For the four trees closest to the roost tree, I recorded and averaged dbh (DBHN), crown class (CROWNN), and decay class (DECAYN); distance of each tree to the roost tree was also recorded (DISTROOST) (Appendix 2.b).

\section{Statistical Analysis}

Roost site use. - A Wilcoxon/Mann-Whitney U-test was used to test for differences between roost tree use in burned and unburned areas (objective 1) and between female and male roost trees (objective 2) (JMP, Version 10. SAS Institute Inc. 2010. Cary, NC: SAS Institute Inc.). Characteristics used in determining differences in roost trees included: dbh, decay stage, crown class, tree height, and percent bark remaining. I compared the distance of the roost tree to the four closest trees, dbh, decay stage and crown class of four nearest trees, and stand basal 
area. I compared percent canopy cover in the four cardinal directions and total gap coverage. I then compared aspect and slope at the roost tree. Measurements of slope and remaining bark were arcsine-transformed and degree (aspect) was cosine-transformed to better approximate normality; however, untransformed means are reported for ease of interpretation. A Pearson's gtest for goodness of fit was used to determine difference in frequency between female and male roost use in burned and unburned areas and between live trees and snag usage. G-values were adjusted using William's 1979 correction equation (McDonald 2009) due to low sample size. Because of small sample size, I present only summary statistics of snag and live roost tree species usage between male and female northern myotis in burned and unburned areas.

\section{RESULTS}

During summer 2011, mist-netting was conducted for 5 nights and resulted in 89 captures including: 52 northern myotis, 15 tri-colored bats, 11 little brown myotis, 8 Indiana myotis, 2 eastern red bats, and one Rafinesque's big-eared bat. Radio transmitters were attached to 32 northern myotis (11 female, 21 male). Sixteen northern myotis ( 8 female, 8 male) roost trees were located: three of the female roost trees were located outside the boundary of the FEF. During summer 2012, mist-netting was conducted for 6 nights and resulted in 25 bat captures including: 21 northern myotis, 3 northern red bats, and one big brown bat. Transmitters were attached to 11 northern myotis ( 8 female, 3 male) and 22 roost trees ( 15 female, 7 male) were located.

Within burned and unburned areas, I located 38 northern myotis roost trees consisting of 10 different tree species of various sizes (Figure 2.1). Red maple, black locust, and red oak were common tree species used for roosting by northern myotis (Table 2.1). Female roosts were most often (6 of 23) located in black locust while males roosted more often (5 of 15) in red maple. Six 
of 8 black locusts identified as roost trees were relic snags, and not the result of prescribed fire based on their lack of bark or branches. Roosts used by female and male northern myotis were located in snags $(47 \%)$ and in live trees (53\%; Table 2.2). Females roosted in snags more often $(57 \%)$ than in live trees (43\%); males roosted in live trees more often $(60 \%)$ than in snags $(40 \%)$ (Table 2.2). Frequency of snag and live tree use by female and male northern myotis was similar (Table 2.3).

Female and male northern myotis roost trees were similar in size $(\mathrm{dbh} \mathrm{cm})($ female $=$ $34.86 \mathrm{~cm} \pm 2.86 \mathrm{SE} ;$ male $\left.=30.87 \mathrm{~cm} \pm 4.04 \mathrm{SE} ; Z_{36}=-1.16 ; P=0.244\right)$, decay stage $($ female $=$ $3.3 \pm 0.40 \mathrm{SE} ;$ male $\left.=2.93 \pm 4.04 \mathrm{SE} ; Z_{36}=-0.565 ; P=0.572\right)$, crown class $($ female $=2.90 \pm$ $0.10 \mathrm{SE} ;$ male $\left.=2.5 \pm 0.27 \mathrm{SE} ; Z_{36}=1.14 ; P=0.256\right)$, and tree height $($ female $=18.88 \mathrm{~m} \pm 2.12$ $\mathrm{SE} ;$ male $\left.=19.87 \mathrm{~m} \pm 2.34 \mathrm{SE} ; Z_{36}=0.00 ; P=1.00\right)$. The mean distance of female and male roost trees from the four nearest surrounding trees (female $=3.96 \mathrm{~m} \pm 0.21 \mathrm{SE}$; male $=4.5 \mathrm{~m} \pm$ 2.19 SE; $\left.Z_{36}=1.26 ; P=0.209\right)$ was also similar. Crown class of the four nearest trees to the roost tree $\left(\right.$ female $=2.01 \pm 0.93 ;$ male $\left.=2.57 \pm 0.67 \mathrm{SE} ; Z_{36}=-3.58 ; P=0.0003\right)$ and the size $(\mathrm{dbh})$ of the four nearest trees $\left(\right.$ female $=29.46 \mathrm{~cm} \pm 1.70 ;$ male $=34.5 \mathrm{~cm} \pm 2.19 \mathrm{SE} ; Z_{36}=-1.06$; $P=0.045)$, were different between sexes. Female northern myotis used roost trees surrounded by smaller trees that were lower in crown class than trees surrounding male roost trees (Table 2.4). Overhead canopy gap $\left(\right.$ female $=19.17 \% \pm 2.93 \mathrm{SE} ;$ male $=9.44 \% \pm 1.82 \mathrm{SE} ; Z_{36}=-2.151 ; P=$ 0.0315) was larger for sites used by females than sites used by males. Female northern myotis used roost trees on steeper, $\left(\right.$ female $=33.30 \% \pm 2.74 \mathrm{SE} ;$ male $=12.07 \% \pm 2.41 ; Z_{36}=-4.09 ; P=$ $<0.0001)$ more northern-facing slopes than male roost trees (Table 2.4).

In 2011, 6 roost trees (male) were found within burned areas and 10 (8 female, 2 male) were found in unburned areas. In 2012, 5 roost trees (4 female, 1 male) were found in burned 
areas. Roost trees not located in burned areas $(n=27)$ were located in unmanaged areas of forest in the FEF not currently under manipulation for fire disturbance (unburned). Two roost characteristics found to be significantly different between sexes were also found to be significantly different between burned and unburned areas: crown class of the 4 nearest trees (burned $=2.63 \pm 0.13 \mathrm{SE} ;$ unburned $=2.07 \pm 0.09 \mathrm{SE} ; Z_{36}=-3.10 ; P=0.0019$ ) and slope (burned $=18.27 \% \pm 6.24 ;$ unburned $\left.=27.63 \% \pm 2.43 ; Z_{36}=-2.195 ; P=0.0281\right)$. Decay stage of 4 nearest trees (burned $=2.05 \pm 0.27 \mathrm{SE}$; unburned $=1.24 \pm .07 \mathrm{SE} ; Z_{36}=2.57 ; P=0.010$ ), and percent northern gap at roost locations was different between burned and unburned areas (burned = $18.63 \% \pm 2.68 \mathrm{SE} ;$ unburned $\left.=10.45 \% \pm 1.63 \mathrm{SE} ; Z_{36}=2.74 ; P=0.0062\right)$. Neighboring trees were more decayed and higher in crown class in burned areas. Roost trees used in burned areas had a greater canopy gap in a north-facing direction, and were located on less steep slopes than roosts located in unburned areas (Table 2.5).

\section{DISCUSSION}

Female northern myotis roosted in 10 different species of hardwood trees, whereas males used 6 different species. This finding coincides with previous studies that report northern myotis using a variety of tree species as roosts (Carter and Feldhamer 2005; Menzel et al. 2002; Lacki et al. 2009). Northern myotis on the FEF readily used relic black locust snags. Menzel et al. (2002) Ford et al. (2006), and Johnson et al. (2009) also reported northern myotis selection of black locusts snags on the FEF. Because black locust was not as abundant historically (Abrams and McCay 1996, Schuler and Gillespie 2000, Ford et al. 2006), the selection of locust in present Central Hardwood Forests may demonstrate flexibility in roost tree species given the species meets the roost requirements of the northern myotis. 
Roost fidelity can be a measure of roost use based on characteristics other than tree species per se and can give insight into whether a tree species is important. Lewis (1987) found roost fidelity was related to the type of roost occupied: high fidelity was directly related to roost permanency and inversely related to roost availability. Because black locust was not a common tree species in the Central Appalachian Mountains prior to the widespread harvesting that occurred regionally from the end of the 1800s into the 1920s (Schuler and Fajvan, 1999), the observed use by northern myotis for roosting may be a relatively new phenomenon. Northern myotis may be selecting for particular cavity and bark characteristics provided by standing dead black locust trees. Moreover, the decay resistance of black locust snags (i.e., permanency) may allow northern myotis to develop strong fidelity to roost sites. Other studies have observed northern myotis using roost areas repeatedly and, to a lesser extent, reusing specific roost trees (e.g. Cryan et al. 2001, Johnson 2009). Benefits of such fidelity may include increased fitness due to familiarity with high-quality roosts and the maintenance of social bonds (Cryan et al. 2001).

Northern myotis on the FEF roosted in both live trees and snags, which is consistent with past findings (Sasse and Pekins 1996; Foster and Kurta 1999; Lacki and Schwierjohann 2001). A similar percent use of live trees (53\% of roosts) was observed on the FEF as reported elsewhere in hardwood forests (53\%; Foster and Kurta 1999). In burned areas, female northern myotis roosted only in snags, while male roosts were equally distributed among snags and live trees. Snags used by female northern myotis had obvious cavities and lacked bark, indicating a high level of decay. Broders et al. (2004) reported female northern myotis using decayed trees 5 times more often than live or recently dead trees. In West Virginia, Menzel et al. (2002) found that female northern myotis formed maternity colonies more often in cavities than under exfoliating bark. 
Female northern myotis on the FEF roosted in snags with greater overhead canopy gap percentage than males. Large canopy gaps allow for increased solar radiation, which may be a selected characteristic of female roosts, as warmer temperatures facilitate more rapid development of neonates (Sedgeley 2001, Boyles and Aubrey 2006, Lausen and Barclay 2006). Johnson et al. (2010) found daily mean and maximum temperatures were higher in areas treated with prescribed fire, which could be due to decay and subsequent falling of trees damaged by fire, creating gaps in the canopy. Female northern myotis were found to roost in areas with greater slope than males. Greater slope could be related to greater fire intensity resulting in more snags and possibly a greater presence of bats. Although of possible biological importance, previous research on the FEF, however, did not find slope to be a predictor of roost selection in northern myotis (Menzel et al. 2002, Johnson et al. 2009).

The location of roost trees in both burned and unburned areas demonstrated a variability of tree usage by northern myotis on the FEF, exploiting characteristics found in both area types. Depending on need and availability, northern myotis may exploit roost trees in areas of burn with larger canopy gaps when present, while also exploiting areas that provide similar habitat in unburned areas where less solar exposure is required (i.e. seasonal or temperature shifts). Broders et al. (2004) found female northern myotis roosting in trees in mid-levels of decay more than live or recently decayed. Such decay stages could be more rapidly acquired through the use of prescribed fire. Female bats responded to alterations to the forest structure by using roost trees located in burned areas. Males also were found exploiting burn areas. Male bats were found using an even proportion of roost locations in burn and unburned areas which is similar to other findings where male northern myotis were found to be less selective in roost habitat (Perry et al. 2007), including roost tree size and location when comparing areas treated with fire to areas left 
unburned. Contrary to prediction, the majority of females were found using unburned areas more than burned areas, with a relatively even distribution between live trees and snags. This may be due to suitable roost tree characteristics within unburned areas (e.g. location of tree in canopy gap, cavities present) and that the necessary requirements for adequate roosts remain in unburned areas even when altered roost trees, such as those exposed to fire, are available in burned areas. Specifically in the FEF, significant roost habitat characteristics included canopy gaps, and size and decay stage of surrounding trees. These characteristics, as well as snag longevity and increased solar radiation in forest canopy gaps can be created through the use of fire.

\section{ACKNOWLEDGMENTS}

Primary funding was provided by the USDA Forest Service Northern Research Station through the National Fire Plan to the Division of Forestry and Natural Resources at West Virginia University. Special thanks to Jane Rodrigue who provided invaluable field guidance and assistance in capturing and telemetry. Thanks also to Andrew Tri for assisting in statistical analysis and other fellow graduate students in providing moral support. Thank you to Dr. Tom Schuler for providing his time, equipment and assistance in canopy coverage photography data collection. Thanks to Donald Lowther and Richard Hovatter of the Northern Research Station's Timber and Watershed Laboratory near Parsons, West Virginia, for assisting in data collection and field travel in the Fernow Experimental Forest.

\section{LITERATURE CITED}

Abrams, M. D., D. M. McCay. 1996. Vegetation-site relationships of witness trees (1780-1856) in the presettlement forests of eastern West Virginia. Canadian Journal of Forest Research. 26: 217-224. 
Animal Care and Use Committee (ACUC), 1998. Guidelines to capture, handling, and care of mammals as approved by the American Society of Mammalogists. Journal of Mammalogy. 79: 1416-1431.

Arroyo-Cabrales, J., T. A. Castaneda, S. 2008. Myotis septentrionalis. In: IUCN 2012. IUCN Red List of Threatened Species. Version 2012.2

Barbour, R. W., W. H. Davis. 1969. Bats of America. University of Kentucky Press, Lexington. $286 \mathrm{pp}$.

Barclay, R. M. R., A. Kurta. 2007. Ecology and behavior of bats roosting in tree cavities and under bark. Pp. 17-59 in Bats in forests: conservation and management (M. J. Lacki, J. P. Hayes, and A. Kurta, eds.). Johns Hopkins University Press, Baltimore,Marylan

Brigham, R. M., M. J. Vonhof, R. M. R. Barclay, J. C. Gwilliam. 1997. Roosting behavior and roost site preference of forest dwelling California myotis (Myotis californicus). Journal of Mammalogy. 78: 1231-1239.

Boyles, J. G., D. P. Aubrey. 2005. Managing forests with prescribed fire: implications for a cavity-dwelling bat species. Forest Ecology and Management 222: 108-115.

Broders, H. G., G. J. Forbes, S. Woodley, I. D. Thompson. 2006. Range extent and stand selection for roosting and foraging in forest-dwelling northern long-eared bats and little brown bats in the greater fundy ecosystem, New Brunswick. Journal of Wildlife Management 70(5): 1174-1184.

Broders, H. G., G. J. Forbes. 2004. Interspecific and intersexual variation in roost site selection of northern long-eared and little brown bats in the Greater Fundy National Park Ecosystem, New Brunswick. Journal of Wildlife Management. 68: 602-610.

Caceres, M. C., R. M. R. Barclay. 2000. Myotis septentrionalis. Mammal. Species. 634: 1-4. 
Campbell, L. A., J. C. Hallet, N. A. O'Connell. 1996. Conservation of bats in managed forests: use of roosts by Lasionycteris noctivagans. Journal of Mammalogy. 177: 976-998.

Carter, T. C., G. A. Feldhamer. 2005. Roost tree use by maternity colonies of Inidana bats and northern long-eared bats in southern Illinois. Forest Ecology and Management. 219: 259268.

Carter, T. C. 2003. Summer habitat use of roost trees by the Endangered Indiana bat (myotis sodalis) in the Shawnee National Forest of southern Illinois. PhD dissertation, Southern Illinois University.

Cryan, P. M., M. A. Bogan, G.M. Yanega. 2001. Roosting habits of four bat species in the black hills of South Dakota. Acta Chiropterologica 3(1): 43-52.

Fenneman, N. M. 1938. Physiography of the Eastern United States. McGraw Hill, New York.

Ford, W. M., S. F. Owen, J. W. Edwards, J.W., J. L. Rodrigue. 2006. Robinia pseudoacacia (black locust) as day-roosts of male Myotis septentrionalis (northern bats) on the Fernow Experimental Forest, West Virginia. Northeastern Naturalist 13: 15-24.

Ford, W. M., M. A. Menzel, J. L. Rodrigue, J. M. Menzel, J. B. Johnson. 2005. Relating bat species presence to simple habitat measures in a central Appalachian forest. Biological Conservation. 126: 528-539

Foster, R. W., A. Kurta. 1999. Roosting ecology of the Northern Bat (Myotis septentrionalis) and comparisons with the endangered Indiana Bat (Myotis sodalis). Journal of Mammalogy 80(2): 659-672.

Frick, W. F., J. F. Pollock, A. C. Hicks, K. E. Langwig, D. S. Reynolds, G. G. Turner, C. M. Butchkoski, T. H. Kunz. 2010. An Emerging Disease Causes Regional Population Collapse of a Common North American Bat Species. Science, p. 329. 
Hamilton, I. M., R. M. R. Barclay. 1994. Patterns of daily torpor and day-roost selection by male and female big brown bats (Eptesicus fuscus). Canadian Journal of Zoology 72: 744-749.

Harvey, M. J., J. S. Altenbach, T. L. Best. 1999. Bats of the United States. Arkansas Game and Fish Commission and U. S. Fish and Wildlife Service, Little Rock, Arkansas.

Hayes, J. P., 2003. Habitat ecology and conservation of bats in western coniferous forests. Mammal Community Dynamics in Coniferous Forests of Western North America: Management and Conservation, Cambridge University Press, Cambridge, UK. p. 709.

Hicks, R. R. 1998. Ecology and management of central hardwood forests. John Wiley \& Sons, Inc.. New York, NY.

Johnson, J. B., J. W. Edwards, W. M. Ford, J. E. Gates. 2009. Roost tree selection by northern myotis (Myotis septentrionalis) maternity colonies following prescribed fire in a central Appalachian hardwood forest. Forest Ecology and Management 258: 233-242.

Johnson J. B. 2010. Roosting ecology of bats in a disturbed landscape. PhD dissertation. West Virginia University. ProQuest/UMI. 2011.

Kerth, G., K. Weissmann, B. Knig. 2001. Day roost selection in female Bechstein's bats (Myotis bechsteinii): a field experiment to determine the influence of roost temperature. Oecologia. 126(1): 1-9.

Kochenderfer, J. N., M. B. Adams, G. W. Miller, J. D. Helvey. 2007. Factors affecting large peakflows on Appalachian watersheds: lessons from the Fernow Experimental Forest. USDA Forest Service, Research Paper NRS-3, Northeastern Research Station, Newtown Square, PA, 24 pp. 
Kochenderfer, J. N. 2006. Fernow and the Appalachian hardwood region. Pages 17-39 In M. B. Adams, D. R. DeWalle, and J. L. Horn, editors. The Fernow watershed acidification study. Springer, Dordrecht, Netherlands. 279 pp.

Lacki, M. J., D. R. Cox, L. E. Dodd, M. B. Dickinson. 2009. Response of northern bats (Myotis septentrionalis) to prescribed fires in eastern Kentucky forests. Journal of Mammalogy. 90(5): 1165-1175.

Lacki, M. J., J. H. Schwierjohann. 2001. Day-roost characteristics of northern bats in mixed mesophytic forest. Journal of Wildlife Management. 65(3): 482-488.

Lausen, C.L., R.M.R. Barclay. 2006. Benefits of living in a building: big brown bats (Eptesicus fuscus) in rocks versus buildings. Journal of mammalogy, 87: $362-370$.

Lewis, S. E. 1995. Roost fidelity of bats: a review. Journal of Mammalogy. 76(2): 481-496.

McDonald, J. H. 2009. Handbook of Biological Statistics (2nd ed.). Sparky House Publishing, Baltimore, Maryland. pp: 80-83.

McShea, W. J., W.M. Healy, P. Devers, T. Fearer, F.H. Koch, D. Stauffer, J. Waldon. 2010. Forestry Matters: Decline of Oaks Will Impact Wildlife in Hardwood Forests. Journal of Wildlife Management, 71(5): 1717-1728.

Menzel, M. A., Carter, T.C., Ford, W.M., Chapman, B.R. 2001. Tree-roost characteristics of subadult and female adult evening bats (Nycticeius humeralis) in the upper Coastal Plain of South Carolina. American Midland Naturalist 145: 112-119.

Menzel, M. A., S. F. Owen, W. M. Ford, J. W. Edwards, P. B. Wood, B. R. Chapman, K. V. Miller. 2002. Roost tree selection by northern long-eared bat (Myotis septentrionalis) maternity colonies in an industrial forest of the central Appalachian Mountains. Forest Ecology and Management 155: 107-114. 
Owen, S. F., M. A. Menzel, W. M. Ford, J. W. Edwards, J. M. Menzel, B. R. Chapman, P. B. Wood, K. V. Miller. 2004. Bat activity in harvested and intact forest stands in the Allegheny Mountains. Northern Journal of Applied Forestry 21: 154-59.

Owen, S. F., M.A. Menzel, W.M. Ford, B.R. Chapman, K.V. Miller, J.W. Edwards, P.B. Wood. 2003. Home range size and habitat used by the northern myotis (Myotis septentrionalis). American Midland Naturalist. 150: 352-359.

Panshin, A. J., Zeeuw, C.D., Brown, H.P. 1964. Textbook of wood technology. McGraw-Hill, New York, p. 643.

Perry, R. W., R. E. Thill. 2007. Roost selection by male and female northern long-eared bats in a pine-dominated landscape. Forest Ecology and Management. 247: 220-226.

Pierson, E. D. 1998. Tall trees, deep holes, and scarred landscapes; conservation biology of North American bats. Pages 309-325 In T. H. Kunz and P. A. Racey, editors. Bat biology and conservation. Smithsonian Institution Press, Washington, D.C.

Reid, F. A. 2006. Peterson's field guide to mammals of North America north of Mexico. Houghton Mifflin Company. New York.

Roverud R. C, M. A. Chappell. 1991. Energetic and thermoregulatory aspects of clustering behavior in the Neotropical bat Noctilio albiventris. Physiological Zoolology. 64(6): $1527-1541$.

Sasse, D. B., P. J. Pekins. 1996. Summer roosting ecology of northern long-eared bats (Myotis septentrionalis) in the White Mountain National Forest. In Bats and Forests Symposium, 19-21 October 1995. Edited by R.M.R. Barclay and M.R. Brigham. Research Branch, B.C. Ministry of Forests, Victoria. pp. 91-101. 
Sedgeley, J. A. 2001. Quality of cavity microclimate as a factor of influencing selection of maternity roosts by a tree-dwelling bat, Chalinolobus tuberculatus, in New Zealand. Journal of Applied Ecology 38: 425-438.

Schuler, T. M. 2004. Fifty years of partial harvesting in a mixed mesophytic forest: composition and productivity. Canadian Journal of Forest Research 34: 985-997.

Schuler, T. M., A.R. Gillespie. 2000. Temporal patterns of woody species diversity in a central Appalachian forest from1856 to 1997. J. Torrey Botanical Society. 127(2): 149-161.

Schuler, T. M., M. A. Fajvan. 1999. Understory tree characteristics and disturbance history of a central Appalachian forest prior to old-growth harvesting. USDA Forest Service, Res. Pap. NE-710, Northeastern Research Station, Radnor, PA.

Trune, D. R., C. N. Slobodchikoff. 1976. Social effects of roosting on the metabolism of the pallid bat (Antrozous pallidus). Journal of Mammalogy. 57: 656-663.

Turbill, C., Geiser, F. 2008. Hibernation by tree-roosting bats. Journal of Comparative Physiology 178(5): 597-605.

Weller, T. J., C. J. Zabel. 2001. Characteristics of fringed myotis day roosts in Northern California. Journal of Wildlife Management 66(3): 489-497.

Willis C. K. R., C. M. Voss R. M. Brigham. 2006. Roost selection by forest-living female big brown bats (Eptesicus fuscus) Journal of Mammalogy 87(2): 345-35. 
Table 2.1. Roost tree species used by Myotis septentrionalis on the Fernow Experimental Forest, 2011 and 2012.

\begin{tabular}{lcccc}
\hline \multirow{2}{*}{ Tree species } & \multicolumn{2}{c}{ Female } & \multicolumn{2}{c}{ Male } \\
\cline { 2 - 5 } & (n) & $\%$ & (n) & $\%$ \\
\hline Robinia pseudoacacia (Black locust) & 6 & 26.1 & 2 & 13.3 \\
Acer rubra (Red maple) & 5 & 21.7 & 5 & 33.3 \\
Quercus rubra (Red oak) & 3 & 13.0 & 3 & 20.0 \\
Acer saccharum (Sugar maple) & 2 & 8.7 & 2 & 13.3 \\
Betula lenta (Black birch) & 2 & 8.7 & & 13.3 \\
Quercus prinus (Chestnut oak) & 1 & 4.3 & 1 & 6.7 \\
Sassafras sp. (Sassafras) & 1 & 4.3 & & \\
Magnolia fraseri (Fraser magnolia) & 1 & 4.3 & & \\
Carya ovata (Shagbark hickory) & 1 & 4.3 & & \\
Liriodendron tulipifera (Yellow-poplar) & 1 & 4.3 & & \\
\hline
\end{tabular}


Table 2.2. Distribution of Myotis septentrionalis roosts in live trees and snags in the Fernow Experimental Forest, 2011 and 2012.

\begin{tabular}{|c|c|c|c|c|}
\hline \multirow[t]{2}{*}{ Tree species } & \multicolumn{2}{|c|}{ Female } & \multicolumn{2}{|l|}{ Male } \\
\hline & Snag & Live & Snag & Live \\
\hline Acer rubra (Red maple) & 2 & 3 & 2 & 1 \\
\hline Robinia pseudoacacia (Black locust) & 4 & 2 & 2 & \\
\hline Quercus rubra (Red oak) & 2 & 1 & & 5 \\
\hline Acer saccharum (Sugar maple) & 2 & & & 3 \\
\hline Betula lenta (Black birch) & 1 & 1 & & \\
\hline Quercus prinus (Chestnut oak) & & 1 & 1 & \\
\hline Sassafras sp. (Sassafras) & & 1 & 1 & \\
\hline Magnolia fraseri (Fraser magnolia) & 1 & & & \\
\hline Carya ovata (Shagbark hickory) & & 1 & & \\
\hline Liriodendron tulipifera (Yellow-poplar) & 1 & & & \\
\hline All species & 13 & 10 & 6 & 9 \\
\hline
\end{tabular}


Table 2.3. Myotis septentrionalis roost trees located in burned and unburned areas in the Fernow Experimental Forest, 2011 and 2012. Pearson's g-test for goodness of fit between sex and burn with adjusted g-values for small sample size.

\begin{tabular}{|c|c|c|c|c|c|c|c|c|c|c|c|c|c|c|}
\hline & \multicolumn{7}{|c|}{ Female } & \multicolumn{7}{|c|}{ Male } \\
\hline & Snag & Live & Total & $g$ & $q^{*}$ & $\mathrm{df}$ & $P$-value & Snag & Live & Total & $g$ & $q^{*}$ & $\mathrm{df}$ & $P$-value \\
\hline Burned & 4 & 0 & 4 & 2.667 & 3.0 & 1 & 0.102 & 3 & 4 & 7 & 0.032 & 4.5 & 1 & 0.858 \\
\hline Unburned & 8 & 11 & 19 & 0.476 & 10.5 & 1 & 0.490 & 3 & 5 & 8 & 0.101 & 5.0 & 1 & 0.750 \\
\hline
\end{tabular}

*Williams 1979 corrected $g$-value: $q=1+\left(\mathrm{a}^{2}-1\right) / 6 \mathrm{nv}(\mathrm{a}=$ number of categories; $\mathrm{n}=$ sample size; $\mathrm{v}=$ degrees of freedom) $(\mathrm{McDonald}$, J.H. 2009. Handbook of Biological Statistics (2nd ed.). Sparky House Publishing, Baltimore, Maryland 
Table 2.4. Myotis septentrionalis roost tree and site characteristics on the Fernow Experimental Forest, 2011 and 2012.

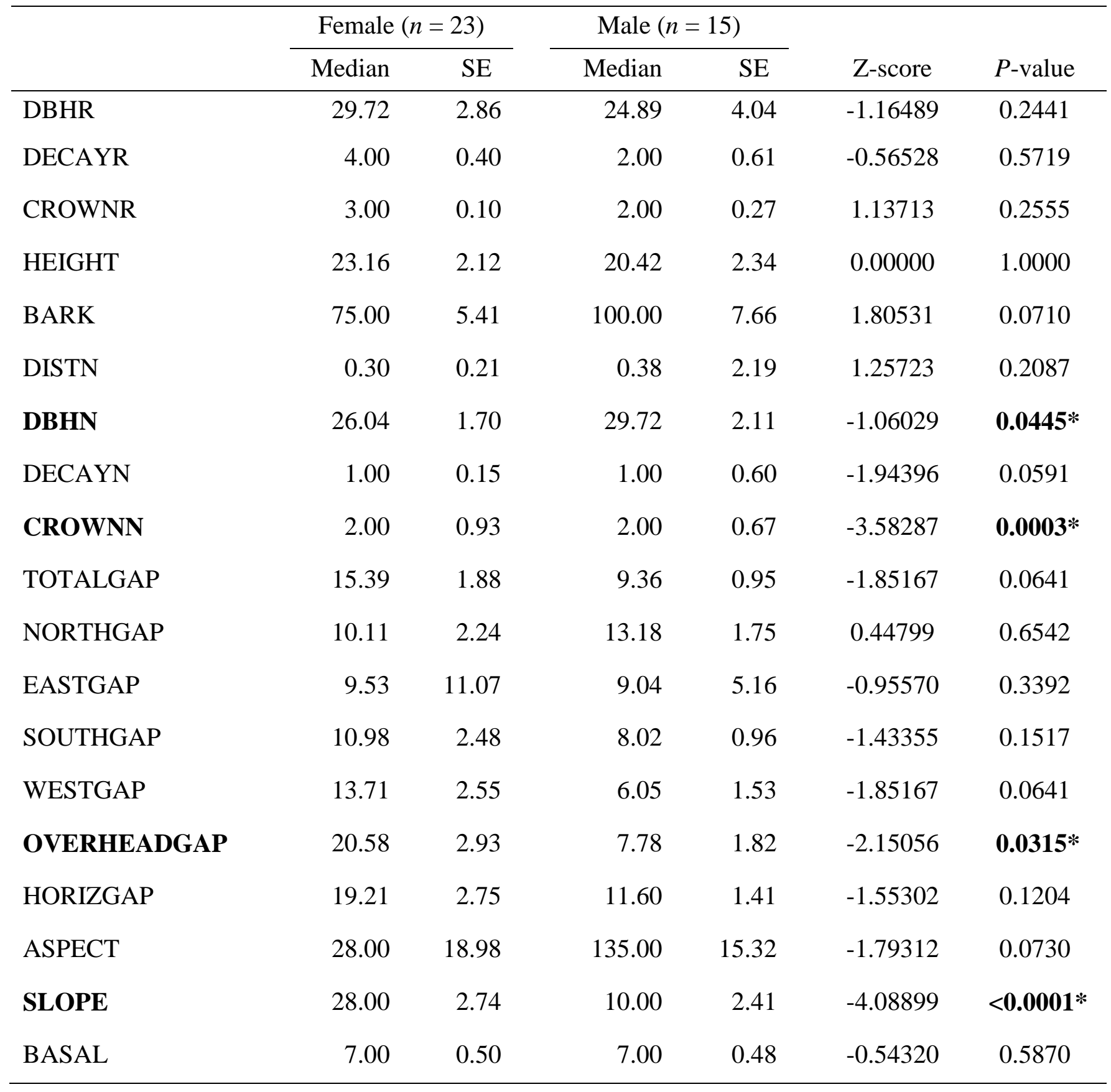


Table 2.5. Myotis septentrionalis roost tree and site characteristics in burned and unburned areas in the Fernow Experimental Forest, 2011 and 2012.

\begin{tabular}{|c|c|c|c|c|c|c|}
\hline & \multicolumn{2}{|c|}{ Burned $(n=11)$} & \multicolumn{2}{|c|}{ Unburned $(n=27)$} & \multirow[b]{2}{*}{ Z-score } & \multirow[b]{2}{*}{$P$-value } \\
\hline & Median & $\mathrm{SE}$ & Median & SE & & \\
\hline DBHR & 25.40 & 2.84 & 29.72 & 3.02 & -1.19111 & 0.2336 \\
\hline DECAYR & 4.00 & 0.57 & 2.00 & 0.42 & 0.27992 & 0.7795 \\
\hline CROWNR & 2.00 & 0.40 & 2.00 & 0.14 & -0.6253 & 0.9501 \\
\hline HEIGHT & 18.14 & 1.91 & 23.62 & 1.82 & -0.90115 & 0.3675 \\
\hline BARK & 75.00 & 7.43 & 75.00 & 5.71 & -0.08387 & 0.9332 \\
\hline DISTN & 0.38 & 1.01 & 0.30 & 0.65 & 1.88119 & 0.0599 \\
\hline DBHN & 30.36 & 2.36 & 26.42 & 1.61 & 1.28386 & 0.1992 \\
\hline DECAYN & 1.00 & 0.27 & 1.00 & 0.07 & 2.57488 & $0.0100 *$ \\
\hline CROWNN & 2.00 & 0.13 & 3.00 & 0.09 & -3.10410 & 0.0019* \\
\hline TOTALGAP & 11.27 & 2.45 & 11.65 & 1.51 & 0.19313 & 0.8469 \\
\hline NORTHGAP & 21.14 & 2.68 & 10.00 & 1.63 & 2.73604 & $0.0062 *$ \\
\hline EASTGAP & 9.04 & 1.08 & 10.31 & 1.98 & -0.32189 & 0.7475 \\
\hline SOUTHGAP & 7.00 & 2.51 & 9.16 & 2.05 & -1.19098 & 0.2337 \\
\hline WESTGAP & 9.75 & 4.19 & 7.47 & 1.75 & 0.77253 & 0.4398 \\
\hline OVERHEADGAP & 7.76 & 4.58 & 13.94 & 2.26 & -0.90138 & 0.3674 \\
\hline HORIZGAP & 11.90 & 4.00 & 14.26 & 2.08 & -0.19313 & 0.8469 \\
\hline ASPECT & 120.00 & 23.88 & 188.00 & 15.75 & -1.73933 & 0.0820 \\
\hline SLOPE & 10.00 & 6.24 & 28.00 & 2.43 & -2.19545 & $0.0281 *$ \\
\hline BASAL & 7.00 & 0.57 & 7.00 & 2.30 & -0.39030 & 0.6963 \\
\hline
\end{tabular}




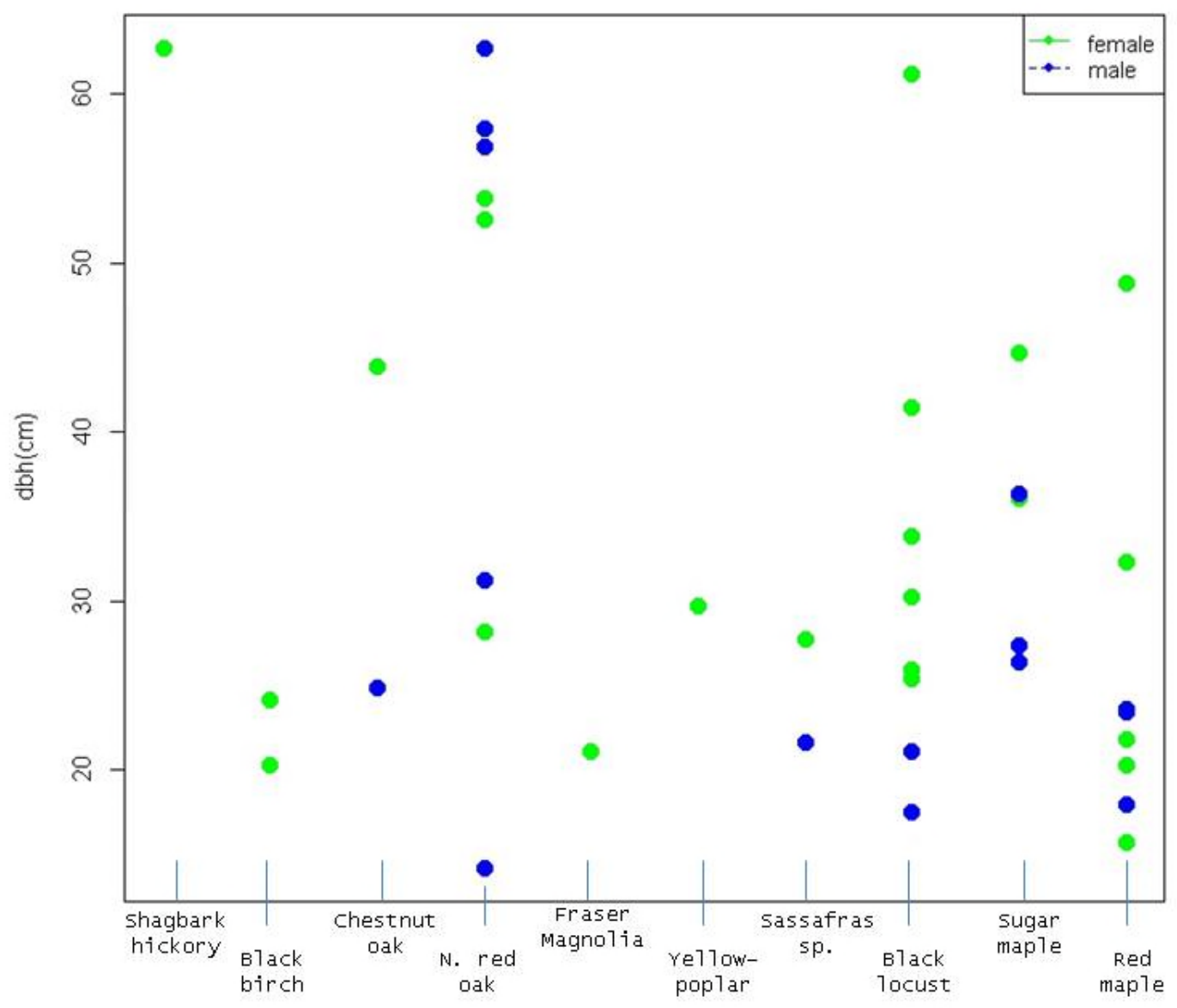

Figure 2.1. Roost tree species used by female and male northern myotis by size $(\mathrm{dbh} \mathrm{cm})$ in 2011 and 2012 in the Fernow Experimental Forest. 


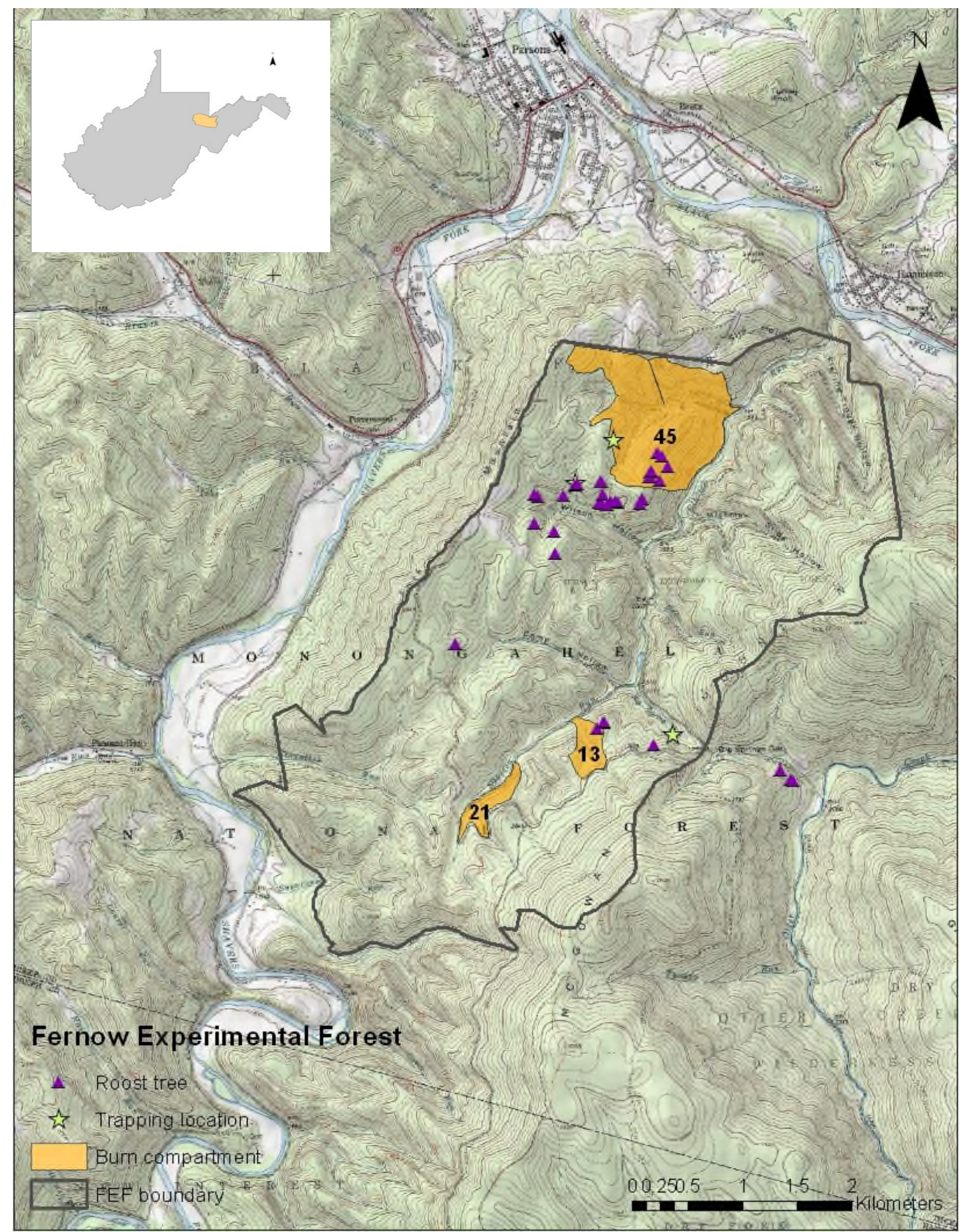

Figure 2.2. Northern myotis roost tree locations within the Fernow Experimental Forest, Tucker County, West Virginia, 2011 and 2012. 
Appendix 2.a. Treatment type and timeline of treatment application for 3 compartments in the Fernow Experimental Forest, West Virginia, 2006 - 2012.

\begin{tabular}{ll}
\hline $\begin{array}{l}\text { COMPARTMENT } 13 \& 21 \\
\text { Date }\end{array}$ & Activity \\
\hline 2006 & plots established \& measured \\
& prescribed fire \\
$2007 \mathrm{a}$ & plots remeasured \\
$2007 \mathrm{~b}$ & herbicide treatment \\
$2007 \mathrm{c}$ & plots remeasured \\
& herbicide treatment \\
$2008 \mathrm{a}$ & prescribed fire* \\
$2008 \mathrm{~b}$ & plots remeasured \\
$2009 \mathrm{a}$ & plots remeasured \\
$2009 \mathrm{~b}$ & Plots remeasured \\
2010 &
\end{tabular}

\section{COMPARTMENT 45}

\begin{tabular}{ll} 
Date & Activity \\
\hline 2006 & plots established \& measured \\
$2007 \mathrm{a}$ & prescribed fire \\
$2007 \mathrm{~b}$ & plots remeasured \\
$2007 \mathrm{c}$ & herbicide treatment \\
$2008 \mathrm{a}$ & prescribed fire* \\
$2008 \mathrm{~b}$ & plots remeasured \\
$2008 \mathrm{c}$ & herbicide treatment \\
2009 & plots remeasured \\
2010 & plots remeasured \\
2012 & plots remeasured \\
\hline
\end{tabular}

* Compartment 45 received re-application of fire one year prior to compartment 13 and 21. 
Appendix 2.b. Total and divided area of compartments and areas of treatments by hectare, including percent area of treatment plots, established in 2006 in the Fernow Experimental Forest.

\begin{tabular}{ccc}
\hline Compartment & Hectares & \% of Total \\
\hline 13 & 13.0 & 8.9 \\
21 & 12.0 & 8.2 \\
45 & 121.0 & 82.9 \\
\cline { 2 - 3 } Total compartments & 146.0 & $100 \%$ \\
\hline
\end{tabular}

\begin{tabular}{lcc}
\hline Treatment plots & Hectares & $\begin{array}{c}\text { \% of Total } \\
(146 \text { hectares })\end{array}$ \\
\hline 20-m radius plot (each) & 0.13 & 0.09 \\
& & \\
Burn only & 3.0 & 2.1 \\
Burn + herbicide & 6.0 & 4.2 \\
Total plot acreage in compartments & 9.0 & $6.3 \%$ \\
\hline
\end{tabular}


Appendix 2.c. Decay stage designation and the characteristics of trees in those decay stages (based on decay of Douglas-fir snags as adapted by Maser et al. 1979).

\begin{tabular}{cl}
\hline Decay stage & Characteristics \\
\hline 1 & Live \\
2 & Live with few limbs broken \\
3 & Dead with all limbs present \\
4 & Dead, few limbs missing, loose bark \\
5 & Few limbs remaining, no bark \\
6 & Broken bole, down material, no limbs \\
7 & Decomposed \\
\hline
\end{tabular}


Appendix 2.d. Crown class designation and associated characteristics of trees in those classes (USDA Forest Service).

\begin{tabular}{|c|c|c|}
\hline Crown class & Definition & Characteristics \\
\hline 1 & Dominant & $\begin{array}{l}\text { Crowns receiving full light from above and partly from the side; } \\
\text { usually larger than average trees or shrubs in stand, with crowns that } \\
\text { extend above the general level of canopy }\end{array}$ \\
\hline 2 & Codominant & $\begin{array}{l}\text { Crowns receiving full light from above, but comparatively little from } \\
\text { sides; crowns usually form general level of canopy }\end{array}$ \\
\hline 3 & Intermediate & $\begin{array}{l}\text { Receiving little direct light from above, none from the sides; usually } \\
\text { with small crowns considerably crowded on sides that are generally } \\
\text { either below or extending into canopy formed by codominant trees or } \\
\text { shrubs }\end{array}$ \\
\hline 4 & Suppressed & $\begin{array}{l}\text { Crowns receiving no direct light either from above or from sides, and } \\
\text { that will not respond to release; usually crowns are entirely below } \\
\text { general level of the canopy }\end{array}$ \\
\hline
\end{tabular}


Appendix 2.e. Characteristics of roost trees used by Myotis septentrionalis in areas that were and were not subjected to prescribed fire on the Fernow Experimental Forest, 2011 and 2012.

\begin{tabular}{|c|c|c|c|c|c|c|}
\hline \multirow[b]{2}{*}{ Variable } & \multicolumn{3}{|c|}{ Burned $(n=11)$} & \multicolumn{3}{|c|}{ Unburned $(n=27)$} \\
\hline & Mean & Median & $\mathrm{SE}$ & Mean & Median & $\mathrm{SE}$ \\
\hline \multicolumn{7}{|l|}{ ROOSTTREE } \\
\hline DBHR (cm) & 28.03 & 25.40 & 2.84 & 35.42 & 29.72 & 3.02 \\
\hline DECAYR & 3.27 & 4.00 & 0.57 & 3.11 & 2.00 & 0.42 \\
\hline CROWNR & 2.63 & 2.00 & 0.40 & 2.75 & 2.00 & 0.14 \\
\hline HEIGHT (m) & 17.73 & 18.14 & 1.91 & 20.85 & 23.62 & 1.82 \\
\hline BARK $(\%)$ & 70.45 & 75.00 & 7.43 & 69.44 & 75.00 & 5.71 \\
\hline \multicolumn{7}{|l|}{ TREECLUSTER } \\
\hline DISTN (m) & 0.37 & 0.38 & 0.03 & 0.32 & 0.30 & 0.02 \\
\hline $\mathrm{DBHN}(\mathrm{cm})$ & 33.47 & 30.36 & 2.36 & 30.62 & 26.42 & 1.61 \\
\hline DECAYN & 2.05 & 1.00 & 0.27 & 1.24 & 1.00 & 0.07 \\
\hline CROWNN & 2.63 & 2.00 & 0.13 & 2.07 & 3.00 & 0.09 \\
\hline \multicolumn{7}{|l|}{ GAP } \\
\hline TOTALGAP (\%) & 13.27 & 11.27 & 2.45 & 12.79 & 11.65 & 1.51 \\
\hline NORTHGAP (\%) & 18.63 & 21.14 & 2.68 & 10.45 & 10.00 & 1.63 \\
\hline EASTGAP (\%) & 8.68 & 9.04 & 1.08 & 12.40 & 10.31 & 1.98 \\
\hline SOUTHGAP (\%) & 8.70 & 7.00 & 2.51 & 12.86 & 9.16 & 2.05 \\
\hline WESTGAP (\%) & 15.07 & 9.75 & 4.19 & 11.19 & 7.47 & 1.75 \\
\hline OVERHEADGAP (\%) & 14.28 & 7.76 & 4.58 & 15.76 & 13.94 & 2.26 \\
\hline HORIZGAP (\%) & 16.94 & 11.90 & 4.00 & 16.94 & 14.26 & 2.08 \\
\hline \multicolumn{7}{|l|}{ SITE } \\
\hline ASPECT $\left(^{\circ}\right)$ & 146.27 & 120.00 & 23.88 & 185.52 & 188.00 & 15.75 \\
\hline SLOPE (\%) & 18.27 & 10.00 & 6.24 & 27.63 & 28.00 & 2.43 \\
\hline BASAL (sq.m./ha) & 6.73 & 7.00 & 0.57 & 6.96 & 7.00 & 0.44 \\
\hline
\end{tabular}


Appendix 2.f. Characteristics of roost trees used by female and male Myotis septentrionalis on the Fernow Experimental Forest, 2011 and 2012.

\begin{tabular}{|c|c|c|c|c|c|c|}
\hline \multirow[b]{2}{*}{ Variable } & \multicolumn{3}{|c|}{ Female $(n=23)$} & \multicolumn{3}{|c|}{ Male $(n=15)$} \\
\hline & Mean & Median & SE & Mean & Median & $\mathrm{SE}$ \\
\hline \multicolumn{7}{|l|}{ ROOSTTREE } \\
\hline DBHR (cm) & 34.86 & 29.72 & 2.86 & 30.87 & 24.89 & 4.04 \\
\hline DECAYR & 3.30 & 4.00 & 0.40 & 2.93 & 2.00 & 0.61 \\
\hline CROWNR & 2.90 & 3.00 & 0.10 & 2.50 & 2.00 & 0.27 \\
\hline HEIGHT (m) & 18.88 & 23.16 & 2.12 & 19.87 & 20.42 & 2.34 \\
\hline BARK $(\%)$ & 64.13 & 75.00 & 5.41 & 78.33 & 100.00 & 7.66 \\
\hline
\end{tabular}

\section{TREECLUSTER}

$\operatorname{DISTN}(\mathrm{m})$

$\mathrm{DBHN}(\mathrm{cm})$

DECAYN

CROWNN

\section{GAP}

TOTALGAP $(\%)$

NORTHGAP $(\%)$

EASTGAP $(\%)$

SOUTHGAP $(\%)$

WESTGAP (\%)

OVERHEADGAP (\%)

HORIZGAP (\%)

$\begin{array}{rrrrrr}3.96 & 0.30 & 0.21 & 4.50 & 0.38 & 2.19 \\ 29.46 & 26.04 & 1.70 & 34.50 & 29.72 & 2.11 \\ 1.66 & 1.00 & 0.15 & 1.00 & 1.00 & 0.60 \\ 2.01 & 2.00 & 0.93 & 2.57 & 2.00 & 0.67\end{array}$

SITE

ASPECT $\left(^{\circ}\right)$

SLOPE (\%)

BASAL (sq.m./ha)
15.27

12.95

13.31

14.49

15.01

19.17

20.34

15.39

10.11

9.53

10.98

13.71

20.58

19.21

191.39

33.30

7.00
1.88

2.24

2.24

2.48

2.55

2.93

2.75

9.44

12.16

2.62

8.27

7.32

8.18

44

12.16

12.16

9.35

9.36

13.18

9.04

8.02

6.05

7.78

11.60
1.41

0.95

1.75

1.03

0.96

1.53

1.82 


\section{CHAPTER 3}

EFFECT OF PRESCRIBED FIRE AND HERBICIDE TREATMENT ON SNAG DYNAMICS IN A HARDWOOD FOREST IN WEST VIRGINIA 
July 2013

Milu Karp

West Virginia University

322 Percival Hall

Morgantown, WV 26506

415/717-9982

milukarp@gmail.com

\title{
EFFECT OF PRESCRIBED FIRE AND HERBICIDE TREATMENT ON SNAG DYNAMICS IN A HARDWOOD FOREST IN WEST VIRGINIA
}

MILU S. KARP, Division of Forestry and Natural Resources, West Virginia University, Morgantown, WV 26506, USA

\begin{abstract}
Snags with cavities and exfoliating bark are an important component of stand structure for wildlife in hardwood forests. Understanding changes in decaying trees over time is needed to manage cavity-dependent biota. I quantified short-term (2006 - 2012) rates of initial tree death and progression through decay stages following fire and herbicide treatments initially applied in spring 2007 in the Alleghany Plateau of West Virginia. Red maple, chestnut oak, northern red oak and sugar maple were the most prevalent species found in measured plots. Northern red oaks were found to live the longest following fire treatment while black locusts were found to decay fastest after treatment. The greatest decline in trees in all treatments was in 2008, one year following initial fire and/or herbicide treatment, with a more gradual decline following in 2012. Transition of trees among decay classes differed by species and size. Prescribed fire alone had the least impact on overall mortality and decay progression for the treatments. Fire tolerance was also positively correlated with tree size, with larger yellow-poplar having the lowest mortality rate after prescribed fire treatment. Prescribed fire had the least amount of impact of the treatments in the rapid progression of trees through decay stages. All non-oak and non-hickory
\end{abstract}


trees found with $>12.7 \mathrm{~cm}$ dbh in plots subjected to herbicide treatment showed a more rapid rate of decline than both fire only and midstory treatments. Snag longevity was significantly greater with increasing diameter for all treatments. Silvicultural practices that increase tree mortality rates and retain snags over long periods of time could be a beneficial approach to management for cavity-dependent wildlife in hardwood forests.

KEY WORDS: Herbicide, mortality, prescribed fire, snag dynamics, West Virginia INTRODUCTION

The dynamics of snag creation, size, and density are subject to various influences throughout the life of the stand (Jones et al. 2009). Forest management practices have traditionally attempted to manipulate structure such that mortality is minimized (Vanderwel et al. 2006). More recently, the recognition of the ecological role of dead trees for wildlife has brought attention to the need for the provision of snags in forest practices (Harmon 2001). Sustainable forestry certification systems have emerged to ensure that the ecological impacts of management are studied and results integrated into management models (Jones et al. 2009). In order to ensure that snags and decaying trees are maintained in the landscape over time, it is important to understand the dynamics of snag creation and their progression over time.

Snag dynamics and the processes that create them in hardwood forests are an important component of wildlife conservation (McComb and Lindenmayer 1999). In many regions of the United States, prescribed fire is a common restoration and management technique in creating snags in forest ecosystems (Ladd 1991). Prior to European settlement in the eastern United States, much of the hardwood forests were thought to have been shaped through fires set by Native Americans (Cottam 1949, Nuzzo 1986, Ladd 1991). Fire is critical in regulating and maintaining a variety of forest ecosystems (Huddle and Pallardy 1996; van Lear 2002) and the 
use of prescribed fire reintroduces an historic disturbance that may be lacking in other silvicultural practices (Boyles and Aubrey 2005). Fire can alter a variety of characteristics in a forest ecosystem, including acting as a mortality agent, which can increase the abundance of snags for wildlife. (Huddle and Pallardy 1996; Arthur et al. 1998; Hartman and Heumann 2003; Aubrey 2004). Fire also alters pathogen susceptibility, which can expedite the formation of cavities (Paulsen 1957; Smith and Sutherland 2001), and opens the forest canopy to more light penetration (Anderson and Brown 1986; Mcarty 1998; Aubrey 2004), which is known to affect roost and den selection (Kurta et al. 1993; Brigham et al. 1997). These characteristics along with a decrease in canopy coverage can be beneficial to cavity nesting and roosting fauna (Van Lear and Watt 1993).

Snags are an important structural component of many forest ecosystems (Harmon et al. 1986). Many wildlife species require standing dead trees as part of their habitat (Loeb and O'Keefe 2006) and maintaining adequate snag abundance and stages of decay is critical to conservation of biodiversity (Delong et al. 2008). In the eastern United States specifically, The Forest Stewardship Council's forest certification standards (Principle 6.3.2b) requires managers to provide for a diversity of habitats such as declining trees and snags in an attempt to provide habitat for a variety of species (Forest Stewardship Council, 2005). Under natural conditions snags are created primarily by weather, fire, insects and disease (Morrison an Raphael 1993). Prescribed fire can lead to the creation and restoration of favorable cavity-dwelling habitat in addition to these natural processes (Boyles and Aubrey 2006). But the effect of prescribed fire on different species of trees varies based on fire intensity and bark thickness. Several studies have found that large snags tend to remain standing longer than small snags (Landrum et al. 2002; Garber et al. 2005). Snag longevity is greater with increasing diameter and decreases with 
increasing stand density (Garber et al. 2005). Moreover, the agent of mortality and the type of treatment applied (e.g. prescribed fire or herbicide) can be important in snag survival (Garber et al 2005). Analyses of snag dynamics should include the species and condition of trees becoming snags as well as the factors causing the tree to die (Morrison and Raphael 1993).

Several studies have examined the effect of fire as well as the present condition of existing snags in hardwood forests. McComb et al. (1983) found higher snag densities in secondgrowth stands than in older-growth forests. Although particular species have been found more prone to the formation of snags (e.g. Robinia pseudoacia and Sassafras albidum; McComb et al.1983), diameter class remains a common determining factor in snag creation and persistence. Russell et al. (2012) found that the size of a snag was significant in estimating its survival, and snag survival increased by as much as $24 \%$ for each $10-\mathrm{cm}$ increase in dbh. This was dependent on species, but due to the suppression of fire in the Central Appalachian forests in the eastern United States, species previously intolerant of fire have been allowed to exceed size classes large enough to tolerate cool to moderate burns (Franklin et al. 2003).

Species composition in hardwood stands can be controlled by selecting trees of desirable form and species and removing undesired trees (Erdmann 1983). In an ideal system, selected crop trees should grow faster and have a greater chance of obtaining and then maintaining dominance in a stand. Obstacles that affect regeneration in a stand include the large variety of species, stem quality, stem density, and growth differences among tree species (Wendel and Lamson 1987). Application of glyphosate ( $N$-(phosphonomethyl)glycine), a broad-spectrum systemic herbicide, can be an effective way to eliminate competition around selected crop trees (Wendel and Lamson 1987). In previous studies conducted in West Virginia, common Appalachian hardwoods were top-killed and did not resprout after two years following injection 
of glyphosate (Wendel and Kochenderfer 1982), and in the five years following, effects of release were still evident. Herbicide application can reduce sprouting by killing competing trees and leaving desired trees (e.g. oaks and hickories) free from competition. Hardwoods killed by herbicide also become snags (Dickson et al. 1995). Conner et al. (1981) found that herbicideinjected trees created snags with fungal heart rots that were capable of providing suitable cavities for wildlife species. Injection of herbicides can also be a safe and clean method of application, compared to the indirect spraying of herbicide, as herbicide is applied directly to the target trees, therefore eliminating some environmental effects (Wendel and Lamson 1987).

There is a need to improve knowledge of the impact of silvicultural actions, including herbicide use, on snag and coarse woody debris (CDW) dynamics in order to develop reliable data connecting management to stand-level habitat features and wildlife communities (Jones et al. 2009). The estimation of snag persistence, which can be defined as the probability of snag survival to a given age, is vital in the creation of management regimes that ensure their availability to wildlife (Garber et al. 2005).

The primary objectives of this study were to (1) identify quantitative changes in snag decay and survival dynamics in a second- and third-growth hardwood forests, (2) estimate the probability of snag survival using decay stage, and (3) quantify the effect of fire and herbicide on tree progression through stages of decay. I predicted that size class of hardwood trees would be positively related to fire tolerance and that all species allowed to reach a larger size class would remain tolerant to prescribed fire and herbicide regardless of bark thickness. I also predicted that trees injected with herbicide would decline at a rapid rate compared to trees subjected to fire only, and that herbicide would be effective in eliminating smaller diameter trees of various species. 


\section{METHODS}

\section{Study Area}

Research was conducted on the Fernow Experimental Forest (FEF) $\left(39.03^{\circ} \mathrm{N}, 79.67^{\circ} \mathrm{S}\right)$ located $^{\circ}$ in Tucker County, West Virginia. The FEF is managed by the United States Forest Service, Northern Research Station. It is located in the central Appalachians approximately $5 \mathrm{~km}$ south of Parsons, West Virginia, in the Unglaciated Allegheny Mountains subsection of the Appalachian Plateau Physiographic Province (Kochenderfer et al. 2007). The FEF was established in 1934 following the designation of the Elklick Run watershed for research and demonstration of forestry practices. When established, the FEF comprised 1,470 ha; it was expanded to approximately 1,900 ha in 1974 (U.S. Forest Service Experimental Forest and Range Network). Geographic features of the forest include an elevation range of 530 to 1115 meters, with Elklick stream running approximately south to north through the forest. Several tributaries intersect ElkLick Run, creating over 5.5 kilometers of streams throughout the forest (Madarish et al. 2002). Mean annual precipitation is $145.8 \mathrm{~cm}$ per year $(9.7 \mathrm{~cm}$ mid-October to $14.4 \mathrm{~cm}$ in June). The mean annual temperature is $9.2^{\circ} \mathrm{C}$ (18.0 in January to 20.6 in July) (Kochenderfer 2006).

The Fernow Experimental Forest vegetation consists of second- and third-growth hardwood stands. The second-growth forest is classified as mixed mesophytic, having characteristics of both mixed-oak and northern hardwood forest types (U.S. Forest Service Experimental Forest and Range Network). Vegetation on the FEF has been managed by evenaged (patch clear-cut), two-age, and uneven-aged (e.g., single-tree selection), and other partial harvesting and thinning silvicultural practices since the mid- $20^{\text {th }}$ century, or left undisturbed following initial harvesting in the Elklick watershed from 1903 to 1911 (Schuler and Fajvan 1999). These practices created a rich mosaic of stand structure. Tree species dominating the 
forest include many shade-tolerant species such as maples (Acer spp.) and beech (Fagus grandifolia). Presently, the variety of tree species dominating this region consists of sugar maple (Acer saccharum), red maple (A. rubrum), yellow-poplar (Liriodendron tulipifera), American beech (Fagus grandifolia), sweet birch (Betula lenta), black cherry (Prunus serotina), and basswood (Tilia americana) (Schuler 2004) (Appendix 3.a).

Recently, prescribed fire has been utilized to encourage oak regeneration and accelerate snag creation in areas where clear-cutting and fire have both been underutilized and suppressed (Schuler 2004). Beginning in 2006, three separate experimental compartments were burned for one day using a strip-head fire technique in the FEF to aid in a better understanding of the effects of fire on regeneration and habitat enhancement. A prescribed fire treatment was applied to 152 ha, consisting of compartment 45 (127 ha), 13 (13 ha) and 21 (12 ha) (Figure 3.6). A total of 72 random plots were established throughout these 3 compartments: compartment 13 and 21 contained 6 plots each and compartment 45 contained 60 plots (Schuler, personal communication 2011). Each 20-m radius plot had plot center marked with a steel bar and the plot number painted on a tree. All trees $>12.7 \mathrm{~cm}$ dbh were measured within each plot and identified with a nail and metal tag with a number at breast height. Species, size $(\mathrm{cm})$, and decay stage was recorded for each tagged tree.

Additionally in 2007,48 of the 72 plots were randomly selected and an herbicide (glyphosate) injection via "hack-squirt" or girdling method treatment applied. The 48 random plots were then identified as one of two treatment types: MIDSTORY or OVERSTORY (Appendix 3.f.). MIDSTORY plots $(n=24)$ consisted of herbicide application to trees with dbh of $12.7-27.9 \mathrm{~cm}$, excluding all oak and hickory species. OVERSTORY plots $(n=24)$ consisted of herbicide application to trees with $\mathrm{dbh}>12.7 \mathrm{~cm}$ excluding all oak and hickory species. The 
remaining 24 plots received only prescribed fire (FIRE treatment). All initial treatments were established in 2006 with subsequent re-treatment and re-measurement in 2008, 2009, 2010, and 2012 (Appendix 3.g.).

Data Collection. - In summer 2012, I re-measured all trees found within each of 65 of 72 plots (6 plots: compartment 13, 6 plots: compartment 21, 53 plots: compartment 45) (Figure 3.5). Seven plots were not re-measured due to inability to locate plots after regeneration of understory and elimination of plot boundary after tree-fall on steep slopes. I recorded: species, dbh, and decay stage (Appendix 3.d) for each tagged tree. Crown class was recorded for live trees (Appendix 3.e). Trees without tags were identified by relative location to surrounding tagged trees, species, and prior dbh recorded in 2010. If the tree number could not be identified based on previous data and the tree was standing and adequate in size $(>12.7 \mathrm{~cm} \mathrm{dbh})$, data was excluded from analysis. If the tree was not located, it was assumed to have fallen and was recorded as coarse woody debris (CWD). In addition, potential roost type was recorded as cavity or adequate bark present. Decay stage and dbh were recorded first in 2006, before initial treatments were applied in 2007. Decay stage was based on previously utilized classification system by the Forest Service to indicate condition of trees ( $1=$ alive, $2-7=$ declining snag) (Appendix 3.d).

Quantifying Mortality Rates. - All tree species subjected to the prescribed fire treatment (FIRE) were placed into one of four categories based on fire tolerance according to Dey (2002): very sensitive, sensitive, intermediate, and resistant (Appendix 3.b). I only used tree species occurring at $\geq 1 \%$ relative frequency in all plots combined in analyses. Tree diameter was divided into two groups: small diameter and large diameter, in order to determine rate of mortality based on size within species. Mean dbh for each species was used to place individuals into either the small diameter or large diameter category; those at or below the mean were placed 
into small and those above were large. Mortality rates were calculated using total number present of a particular species, number of snags present in 2006 (before treatment) minus number of snags present in 2012. The final number of snags in 2012 was divided by the total number of live trees. These percentages were then averaged for each fire-tolerance level. The mortality rate for individual trees subjected to the FIRE treatment was calculated in order to quantify the effect of prescribed fire without herbicide injection on trees species. All oak and hickory species were included in the FIRE treatment mortality estimates. Oaks and hickories were removed from analysis of MIDSTORY and OVERSTORY treatment effects, as oaks and hickory species were not treated with herbicide as part of study design. Percent mortality for FIRE treatment plots was also calculated in order to quantify effects of prescribed fire alone without additional herbicide application on species.

Quantifying snag progression and survival. -Progression of all trees through decay stages from 2006 to 2012 was determined for each treatment. Trees that were not located in 2012 were considered no longer standing, and were classified as coarse woody debris (CWD). The percentage of trees identified in each decay stage was calculated based on total number of trees present $(n)$ in 2006 and again in 2012. These progression percentages through decay stages were separated by treatments. Oak and hickory species were removed from count analysis of MIDSTORY and OVERSTORY treatments.

To determine the effect of tree size $(\mathrm{dbh} \mathrm{cm})$ on tree mortality and survival, all species present with $\geq 1 \%$ frequency were divided into 1 of 6 size classes: size class $1(10-19.9 \mathrm{~cm}$ $\mathrm{dbh})$, size class $2(20-29.9 \mathrm{~cm} \mathrm{dbh})$, size class $3(30-39.9 \mathrm{~cm} \mathrm{dbh})$, size class $4(40-59.9 \mathrm{~cm}$ dbh), size class 5 (60-79.9 cm dbh), and size class 6 (80 - $100 \mathrm{~cm} \mathrm{dbh)} \mathrm{(Appendix} \mathrm{3.h.).} \mathrm{The}$ number of years a particular tree remained alive after treatment (YEARSALIVE) was calculated 
based on decay stage. Trees identified as live (1) in 2006 were given a decay stage classification for every year following (with the exception of 2011). A tree was identified as live until given a decay classification of 2 or higher.

I calculated survival rate for each treatment using a Kaplan-Meier estimator (JMP, Version 10. SAS Institute Inc., Cary, NC, 2010). Survival rate was estimated for various size classes. Survival rate was also estimated for size class by each treatment type from 2006 to 2012. Oak and hickory species were excluded from survival analysis. An analysis of variance (ANOVA) was used to determine if the effect of treatment type on all sizes and species (excluding oak and hickory) was different and if survival of trees differed based on size class. The average number of years that a tree remained living after treatment in 2007 within each size class was calculated to determine the effect of size on each treatment type.

\section{RESULTS}

Mortality Rates. -Within the FIRE treatment, yellow-poplar (21.4\%), black oak (Quercus velutina) (28.6\%), and bitternut hickory (Carya cordiformis) (28.6\%) had the lowest percent mortality for the small dbh size class. Black locust (100\%) and scarlet oak (Quercus coccinea) (90\%) had the highest percent mortality for small-diameter trees. For large-diameter trees, black gum (Nyssa sylvatica) (0\%) and yellow-poplar (12.5\%) had the lowest percent mortality, while black locust (100\%) and American beech (77.3\%) had the highest percent mortality (Table 3.1). Trees designated as resistant to fire had the lowest mean percent survival (23.3\%), while trees grouped as having intermediate resistance to fire had the highest mean percent mortality (66.7\%) (Table 3.1).

Snag progression and survival. - Within treatments, all species were assigned a decay stage value based on condition from 2006 to 2012 (Figure 3.1). The total number of trees 
subjected to FIRE $(n=788)$, MIDSTORY $(n=782)$, and OVERSTORY $(n=789)$ were aggregated by decay stage. In 2006, FIRE treatment consisted of $91 \%$ alive, MIDSTORY had 91\% alive, and OVERSTORY had $88 \%$ alive prior to treatment. By $2012,41 \%$ of trees in FIRE treatment remained in decay stage 1 (alive), 17\% of MIDSTORY, and 1\% of OVERSTORY trees remained living. For FIRE treatment, the largest percent of trees remained in the first 2 decay stages (decay stage $2=19 \%$; recently dead/declining). FIRE treatment also resulted in the lowest percent of CWD trees (20\%) (Table 3.2). For MIDSTORY treatment, the largest percentage of trees remained in decay stage 4 (14\%; broken top/loose bark) and 5 (18\%; few remaining limbs/no bark) (Table 3.3). For OVERSTORY treatment, the majority of trees also remained in decay stage 4 (24\%), 5 (14\%) and 6 (14\%; broken bole/down material/no limbs) (Table 3.2). Trees subjected to OVERSTORY treatment also had the greatest percentage of downed trees $(\mathrm{CWD}=39 \%)$.

Based on the Kaplan-Meier survival estimate values for the three treatments, FIRE treatment maintained the highest rate of survival from 2006 to 2012 (Figure 3.2). The lowest survival rate was in 2012, where $66 \%$ of trees in the FIRE treatment remained alive while $22 \%$ of those in MIDSTORY treatment and 11\% in OVERSTORY treatment remained living 4 years after initial treatment (Table 3.2). After 2008, survival rates declined most severely, with a change from $73 \%$ to $23 \%$ in MIDSTORY and $68 \%$ to $2 \%$ in the OVERSTORY treatments, respectively. FIRE treatment allowed for the slowest rate of decline over 5 years, with most substantial loss occurring after 2010 (Figure 3.2). MIDSTORY and OVERSTORY treatments resulted in similar rates of decline following treatments in 2007, and resulted in the most substantial loss after 2008. After 2009, both MIDSTORY and OVERSTORY treatments resulted 
in more gradual decline of trees (Figure 3.2). The survival of trees among years was significantly different $(P<0.001)$ among treatment types $(\chi 2=528.16, d f=2)$.

A Kaplan Meier survival estimate was calculated for trees in each of the 6 size classes (Figure 3.3). Size class $1(10-19.9 \mathrm{~cm} \mathrm{dbh})$ trees had the lowest probability of survival after 5 years of treatment: 88\% survival rate in 2006 to 9\% survival rate in 2012 (Figure 3.3). Trees in size class $6(80-100 \mathrm{~cm} \mathrm{dbh})$ had $100 \%$ survival rate after 5 years of treatment. The probability of survival of trees among years was significantly different $(P<0.001)$ among size classes based on the Wilcoxon non-parametric test $(\chi 2=294.42, d f=5)$.

Because I found evidence of significant differences among both treatment types and size classes, I further analyzed the effects of size class within each treatment type (Figure 3.4). Size class 1 had the lowest probability of survival for all three treatment types compared to all other size classes $(\mathrm{FIRE}=0.27, \mathrm{MIDSTORY}=0.00, \mathrm{OVERSTORY}=0.00)$ after 6 years, while higher size classes had a higher probability of survival, regardless of treatment type (e.g. size class 4: FIRE $=0.74$, MIDSTORY $=0.73$, OVERSTORY $=0.05)$. After 2008, OVERSTORY herbicide treatment had a detrimental effect on all trees, regardless of size class. FIRE treatment had the most gradual effect on decline of all trees (Figure 3.4).

\section{DISCUSSION}

Tree mortality rates are one of the key factors controlling the long-term dynamics of forest ecosystems (Dietze et al. 2011). Prescribed burning and its effect on mortality has been shown to alter succession in various communities (Luken, 1990). Several of the mesophytic species normally considered fire intolerant have attained large enough diameter in eastern deciduous forests to be tolerant of cool to moderate burns (Franklin et al. 2003). The mortality rates of larger trees in the FEF (>60 cm dbh), regardless of species or previously designated fire- 
tolerance level, were found to resist, at least in the short-term, the detrimental effects of fire and herbicide application. Smaller diameter trees were eliminated from the plots 6 years following treatment of fire and herbicide. This rate of mortality on smaller diameter trees is effective in eliminating small, shade-tolerant species such as Acer spp., allowing for the regeneration and competitive advantage of Quercus spp. The overall low mortality rate of trees such as yellowpoplar can be associated with the relatively larger average mean dbh of those present in the FEF.

Based on the rate of decay observed in the FEF, it was also determined that the rate at which larger trees decay is slower than that of smaller trees. Large trees have a greater proportion of decay-resistant heartwood than smaller ones (Sellin 1994). This characteristic may extend the time larger trees are able to withstand the effects of decay from rot caused by fire and herbicide before falling (Vanderwel et al. 2006). Inherent differences in wood density and the concentration of lignin may also result in different rates of decay among hardwood species (Harmon 2001). The agent of mortality can be an important factor in determining snag longevity (Garber et al. 2005). On the FEF, both the size of trees and the treatment (fire alone or fire in combination with the application of herbicide) was significantly associated with survival and rate of decay. Trees killed by fire decayed slower than those injected with herbicide after being subjected to fire. Results from this study suggest that for smaller diameter trees, fire can be an effective tool in snag creation, while herbicide treatment in addition to fire leads to a more rapid decline and subsequent rapid falling of the majority of trees ( $<5$ years). Such expedited decline to a CWD stage can be ineffective for the creation of snags for wildlife requiring standing trees with cavities, crevices, and exfoliating bark. For larger trees, regardless of bark thickness, fire alone may provide a management technique for snag creation of larger, longer standing trees. Based on the observed rate of decline among treatments, fire is effective in eliminating small 
diameter trees, which can be beneficial in the elimination of shade-tolerant species (e.g. Acer spp.). Fire treatment also allowed for larger diameter trees to remain standing longer than those treated with herbicide injection. These longer-standing, declining snags are necessary in creating habitat for wildlife species that demonstrate philopatry to particular locations and particular trees in hardwood forests.

Although responses varied among species treated with fire alone and fire with herbicide, all treatments were effective in the creation of snags. Comparatively, prescribed fire alone leads to a slower decline in snag development. Yellow-poplar, a tree identified as resistant to fire in mature stage responded to FIRE treatment with the lowest rate of decline through decay stages (21.4\% mortality for small trees; $12.5 \%$ for large trees; size class determined by mean). Following the application of herbicide, yellow-poplar responded with a mortality rate similar to FIRE $(17.0 \%)$. My results indicate that small hardwood trees $($ smallest diameter $=12.7 \mathrm{~cm})$ treated with FIRE had the highest mortality rate of all three treatments, which suggests that prescribed fire alone can be effective in eliminating small diameter trees without the use of herbicide. Mortality rates for smaller dbh trees remained consistently higher for all species after FIRE treatment as compared to larger dbh trees. Russell et al. (2012) found that snag survival and decomposition is related to snag dbh and average time in a given decay stage rather than tree species. These results found on the FEF also suggest that fire is successful in achieving a slower decline rate than the use of herbicide.

Rates of survival are a helpful tool in predicting rate of decline over time. The ability to estimate snag persistence requires adequate time for analysis. Estimated rates of mortality and decay stage progression using short-term records ( $<20$ years) (Morrison and Raphael 1993; Mellen and Ager 2002) will likely result in the overestimation of snag progression rates (DeLong 
et al. 2008). Morrison et al. (1993) found that snags tended to remain in the most decayed stages for at least 5-10 years before falling. Although there was a net increase in snag creation in the FEF from 2006 to 2012, most of the increase was due to the decay of smaller (10-30 cm dbh) trees, regardless of species. Species of snag was found to be relatively less important with regard to snag longevity than the method of creation or tree diameter. For OVERSTORY treatments, a smaller percentage of trees remained in decay stage one, indicating a faster progression through snag stages (only $21.8 \%$ of trees remained alive after treatment while $47.2 \%$ of trees remained in the decay stage 1 after FIRE treatment) with a near complete loss of all trees, with the exception of two larger-diameter trees. Trees subjected to FIRE showed slower progression into higher decay stages. MIDSTORY treatment plots had the highest transition to mid-decay stage (4) at $40.8 \%$ of total trees measured. This progression towards a mid-level stage of senescence may be beneficial. Rapid loss (large number of trees moving to high decay stages) as observed in OVERSTORY treatment plots without replacement of snags could be counterproductive with the loss of potential living trees that could be recruited into the snag population (Morrison et al. 1993).

A tree species' fire rating will vary depending on fire intensity, duration of fire, time of year and the maturity of the trees (Lambert 2001). Trees of different ages can vary in their resistance, thus requiring size to become a critical variable. Fire damage can also be affected by the season in which the burn is applied. Hot, intense, slow-burning fires will kill more trees than less intense, fast-burning fires (Lambert 2001). Fire treatment on the FEF was not monitored for intensity (i.e., temperature), yet the impact of fire combined with herbicide injection had a substantial impact of snag creation on a variety of species. Based on rate of progression through 
decay stages and number of years a tree remained standing after treatment, FIRE had the most gradual effect on tree senescence.

\section{ACKNOWLEDGMENTS}

Primary funding was provided by the USDA Forest Service Northern Research Station through the National Fire Plan to the Division of Forestry and Natural Resources at West Virginia University. The re-measuring of 3,700 trees would not have been possible nor as entertaining without assistance in the field from my technician Justin Lewis. Thanks also to Andrew Tri for assisting in statistical analysis and other fellow graduate students in providing moral support. Thank you to Dr. Tom Schuler and Freddie Wood for providing snag data. Thanks to Donald Lowther and Richard Hovatter of the USDA Northern Research Station for assisting a Colorado gal in the proper identification of West Virginia hardwood trees.

\section{LITERATURE CITED}

Anderson, R. C., Brown, L. E., 1986. Stability and instability in plant communities following fire. American Journal of Botany. 73: 364-368.

Arthur, M. A., R. D. Paratley, B. A. Blakenship, 1998. Single and repeated fires affect survival and regeneration of woody and herbaceous species in an oakpine forest. J. Torrey Botany Society 125: 225-236.

Aubrey, D. A. 2004. Savanna restoration through prescribed fire: demographic and physiological responses of oak and hickory seedlings and saplings to a changing light environment. Master's Thesis, Southwest Missouri State University.

Brigham, R. M., Vonhof, M.J., Barclay, R.M.R., Gwilliam, J.C. 1997. Roosting behavior and roost-site preferences of forest-dwelling California bats (Myotis californicus). Journal of Mammalogy 78: 1231-1239.

Boyles, J. G., and D. P. Aubrey. 2006. Managing forests with prescribed fire: implications for a 
cavity-dwelling bat species. Forest Ecology and Management 222: 108-115.

Conner, R. N. 1987. Snag management for cavity nesting birds. R.M. DeGraaf tech. coord. Proceedings of the workshop management of southern forests for nongame birds. U.S.D.A. Forest Service Gen. Tech. Report. SE-14. Pp. 120-128.

Conner, R. N., J.G. Dickson, B.A. Locke. 1981. Herbicide-killed trees infected by fungi: potential cavity sites for woodpeckers. Wildlife Society Bulletin, 9(4): 308-310.

Cottam, G. 1949. The phytosociology of an oak woods in southwestern Wisconsin. Ecology 30: 271-287.

DeLong, S. C., G. D. Sutherland, L.D. Daniels, B.H. Heemskerk, K.O. Storaunet. 2008. Temporal dynamics of snags and development of snag habitats in wet spruce-fir stands in east-central British Columbia. Forest Ecology and Management 225: 3613-3620.

Dey, D. 2002. The ecological basis for oak silviculture in Eastern North America. Chapter 5 In: McShea W.J. and Healy, W.M. (Eds.) Oak Forest Ecosystems - Ecology and Management for Wildlife. The Johns Hopkins University Press, Baltimore.

Dickson, J. G., J. H. Williamson, R. N. Conner. 1995. Longevity and bird use of hardwood snags created by herbicides. Proc. Annual Conference SEAFWA. 49: 332-339.

Fan, Z., S. R. Shifley, M. A. Spetich, F. R. Thompson III, D. R. Larsen. 2003. Distribution of cavity trees in Midwestern old-growth and second-growth forests. Canadian Journal of Forest Resources 33:1481-1494.

Franklin, S. B., P. A. Robertson, J. S. Fralish. 2003. Prescribed burning effect on upland Quercus forest structure and function. Forest Ecology and Management 184: 315-335.

Franklin, S. B. 1996. Disturbance effects on upland Quercus community dynamics of Land Between the Lakes, Kentucky and Tennessee. PhD dissertation. Department of Plant 
Biology, Southern Illinois University, Carbondale.

Garber, S. M., J. P. Brown, D. S. Wilson, D. A. Maguire, L. S. Heath. 2005. Snag longevity under alternative silvicultural regimes in mixed-species forests of central Maine. Canadian Journal of Forest Resources 35: 787-796.

Harmon, M. E. 2001. Moving towards a new paradigm for dead wood management. Ecological Bulletin 49: 269-278.

Harmon, M.E., J. F. Franklin, F.J.Swanson. 1986. Ecology of coarse woody debris in temperate ecosystems. Advances in Ecological Research 18: 132 pp.

Hartman, G. W., Heumann, B.H. 2003. Prescribed fire effects in the Ozarks of Missouri: the Chilton Creek project 1996-2001. In: Proceedings of the Second International Wildland Fire Ecology and Fire Management Congress, 16-22 November, 2003, Orlando, FL.

Hicks, R. R. 1998. Ecology and management of central hardwood forests. John Wiley \& Sons, Inc.. New York, NY.

Huddle, J. A., Pallardy, S.G. 1996. Effects of long-term annual and prescribed burning on tree survival and growth in a Missouri Ozark oak-hickory forest. Forest Ecology and Management 82: 1-9.

Jones, P. D., B. Hanberry, S. Demarais. 2009. Stand-level wildlife habitat features and biodiversity in southern pine forests: a review. Journal of Forestry, 8 pp.

Kochenderfer, J. N. 2006. Fernow and the Appalachian hardwood region. Pages 17-39 In M. B. Adams, D. R. DeWalle, and J. L. Horn, editors. The Fernow watershed acidification s study. Springer, Dordrecht, Netherlands. 279 pp.

Kochenderfer, J. N., M. B. Adams, G. W. Miller, J. D. Helvey. 2007. Factors affecting large peakflows on Appalachian watersheds: lessons from the Fernow Experimental Forest. 
USDA Forest Service, Research Paper NRS-3, Northeastern Research Station, Newtown Square, PA. 24 pp.

Kurta, A., D King, J.A Teramino, J. M. Stribley, K. J. Williams. 1993. Summer roosts of the endangered Indiana bat (Myotis sodalis) on the northern edge of its range. American Midland Naturalist. 129: 132-138.

Ladd, D. 1991. Reexamination of the role of fire in Missouri oak woodlands. In: Buger, G.V., Ebinger, J.E., Wilhelm, G.S. (Eds.), Proceedings of the Oak Woods Management Workshop, Eastern Illinois University, Charleston. pp. 67-80.

Lambert, S. M. 2001. Tree/shrub list indicating fire tolerance/survival and regrowth estimates for eastern Washington and eastern Oregon. USDA Natural resources Conservation services.

Landrum, M.F., Laudenslayer Jr., W. F., T. Atzet. 2002. Demography of snags in eastside pine forests of California. In: Laudenslayer Jr., W.F., Shea, P.J., Valentine, B.E., Weatherspoon, P.C., Lisle, T.E. (Technical Coordinators). Proceedings of the Symposium on the Ecology and Management of Dead Wood in Western Forests. USDA For. Serv. Gen. Tech. Rep., PSW-181. Pacific Southwest Research Station, Albany, CA, 2002. 949 pp.

Larson, P. R. 1963. Stem Form Development of Forest Trees. Forest Science. pp. a0001

Lindenmayer, D. B., J. T. Wood. 2010. Long-term patterns in decay, collapse, and abundance of trees with hollows in the mountain ash (Eucalyptus regnans) forests of Victoria, southeastern Australia. Canadian Journal of Forest Resources 40: 48-54.

Linder, P., L. Ostlund. 1998. Structural changes in three mid-boreal Swedish forest landscapes. 1885 - 1996. Biological Conservation 85: 9-19.

Loeb, S.C., J. M. O'Keefe. 2006. Habitat use by forest bats in South Carolina in relation to local, 
stand, and landscape characteristics. Journal of Wildlife Management. 70: 1210-1218.

Luken, L. O. 1990. Directing ecological succession. Chapman and Hall, NY.

Madarish, D. M., J. L. Rodrigue, M. B. Adams. 2002. Vascular flora and macroscopic fauna of the fernow experimental forest. Volume 291 of USDA, Forest Service.

McCarty, K. 1998. Landscape-scale restoration in Missouri savannas and woodlands.

Restoration Management. Notes 16: 22-32.

McComb, W., D. Lindenmayer. 1999. Dying, dead and down trees. Maintaining biodiversity in forest ecosystems. Cambridge University Press, Cambridge, UK. pp. 335-372.

McComb, W.C., R.N. Muller. 1983. Denstities in old-growth and second-growth Appalachian forests. The Journal of Wildlife Management. 47: 376-383.

Mellen, K., A. Ager. 2002. A coarse wood dynamics model for the western cascades. Proceedings of the Symposium on the Ecology and Management of Dead Wood in Western Forests. USDA For. Serv. Gen. Tech. Rep., PSW-181. Pacific Southwest Research Station, Albany, CA, 2002. 949 pp.

Merritt, C., Pope, P. E. 1991. The Effect of Environmental Factors, Including Wildfire and Prescribed Burning, on the Regeneration of Oaks in Indiana. Purdue University Natural Resource, Station Bulletin 612.

Morrison, M. L., M. G. Raphael. 1993. Modeling the dynamics of snags. Ecological Applications 3: $322-330$.

Nuzzo, V.A. 1986. Extent and status of Midwest oak Savanna: presettlement and 1985. Natural Areas Journal 6: 6-36.

Paulsell, L. K. 1957. Effects of burning on Ozark hardwood timberlands. University of Missouri College of Agriculture, Agricultural Experimental Station Bulletin 640. 
Russell, M. B., A. R. Weiskittel. 2012. Assessing and modeling snag survival and decay dynamics for the primary species in the Acadian forest of Maine, USA. Forest Ecology and Management 284: 230-240.

Sellin, A. 1994. Sapwood-heartwood proportion related to tree diameter, age, growth-rate in Picea abies. Canadian Journal of Forest Resources. 24:1022-1028.

Schuler, T. M. 2004. Fifty years of partial harvesting in a mixed mesophytic forest: composition and productivity. Canadian Journal of Forest Research 34: 985-997.

Schuler, T. M., M. A. Fajvan. 1999. Understory tree characteristics and disturbance history of a central Appalachian forest prior to old-growth harvesting. USDA Forest Service, Res. Pap. NE-710, Northeastern Research Station, Radnor, PA.

Teuke, M. J., D. H. Van Lear. 1982. Prescribed Burning and Oak Advance Regeneration in the Southern Appalachians. Georgia Forestry Commission Resource Paper 30.

Smith, K. T., Sutherland, E. K., 2001. Terminology and biology of fire scars in selected central hardwoods. Tree-Ring Res. 57: 141-147.

Van Lear, D. H.; Watt, J. M. 1993. The role of fire in oak regeneration. In: Loftis,D.; McGee, C. eds. Proceedings, oak regeneration: serious problems, practical recommendations. Gen. Tech. Rep. SE-84. Knoxville, TN: U.S. Department of Agriculture, Forest Service, Southeastern Forest Experiment Station: 66-78.

Van Lear, D. H. 2002. Upland oak ecology and management. In: Spetich, M.A. (Ed.), Upland Oak Ecology Symposium: History, Current Conditions, and Sustainability.Vanderwel, M. C., J. P. Caspersen, M. E. Woods. 2006. Snag dynamics in partially harvested and unmanaged northern hardwood forests. Canadian Journal of Forest Resources 36: 276927. 
Wendel, G. W., N. I. Lamson. 1987. Effects of herbicide release on the growth of 8- to 12-yearold hardwood crop trees. U.S.D.A. Forest Service. NE-RP-198.

Wendel, G. W., J. N. Kochenderfer. 1982. Glyphosate controls hardwoods in West Virginia. U.S.D.A. Forest Service, Northeastern Forest Experimental Station. NE-RP-497. 
Table 3.1. Percent mortality for tree species (>1\% frequency) subjected to FIRE treatment in the Fernow Experimental Forest, West Virginia, 2012 (fire tolerance based on Gleason 1913: The Relation of Forest Distribution and Prairie Fires in the Middle West).

\begin{tabular}{|c|c|c|c|c|c|c|c|}
\hline Fire tolerance & $\begin{array}{l}\text { Number of } \\
\text { stems }\end{array}$ & $\begin{array}{c}\text { Small } \\
\text { diameter } \\
(\mathrm{cm})\end{array}$ & SE & $\begin{array}{c}\% \\
\text { mortality }\end{array}$ & $\begin{array}{c}\text { Large } \\
\text { diameter } \\
(\mathrm{cm})\end{array}$ & SE & $\begin{array}{c}\% \\
\text { mortality }\end{array}$ \\
\hline \multicolumn{8}{|l|}{ Very sensitive } \\
\hline Sourwood (Oxydendron arboreum) & 131 & 16.3 & 0.2 & 75.0 & 24.8 & 0.7 & 53.7 \\
\hline \multirow[t]{2}{*}{ Black locust (Robinia pseudoacacia) } & 20 & 17.7 & 1.0 & 100.0 & 21.9 & 2.5 & 100.0 \\
\hline & & & & 87.5 & & & 76.9 \\
\hline \multicolumn{8}{|l|}{ Sensitive } \\
\hline Sweet birch (Betula lenta) & 139 & 17.7 & 0.5 & 60.5 & 31.5 & 1.2 & 54.8 \\
\hline Cucumbertree (Magnolia acuminata) & 37 & 22.9 & 0.7 & 63.2 & 36.1 & 1.7 & 41.2 \\
\hline Sugar maple (Acer saccharum) & 120 & 16.3 & 0.3 & 51.5 & 31.9 & 1.5 & 39.2 \\
\hline Red maple (Acer rubrum) & 221 & 16.7 & 0.2 & 60.2 & 30.1 & 0.7 & 54.7 \\
\hline \multirow[t]{2}{*}{ American beech (Fagus grandifolia) } & 80 & 15.7 & 0.4 & 60.0 & 22.4 & 1.1 & 77.3 \\
\hline & & & & 59.1 & & & 53.4 \\
\hline \multicolumn{8}{|l|}{ Intermediate } \\
\hline Scarlet oak (Quercus coccinea) & 19 & 33.0 & 2.0 & 90.0 & 53.3 & 2.6 & 33.3 \\
\hline \multicolumn{8}{|l|}{ Resistant } \\
\hline Yellow-poplar (Liriodendron tulipifera) & 60 & 30.7 & 1.9 & 21.4 & 50.6 & 1.3 & 12.5 \\
\hline Black gum (Nyssa sylvatica) & 10 & 17.2 & 1.4 & 66.7 & 35.1 & 7.6 & 0.0 \\
\hline Black oak (Quercus velutina) & 14 & 36.1 & 1.7 & 28.6 & 51.2 & 2.0 & 28.6 \\
\hline Bitternut hickory (Carya corfiformis) & 11 & 19.6 & 2.0 & 28.6 & 45.7 & 5.0 & 25.0 \\
\hline White oak (Quercus alba) & 47 & 20.3 & 1.0 & 60.9 & 43.7 & 2.5 & 23.5 \\
\hline Chestnut oak (Quercus prinus) & 159 & 26.3 & 0.7 & 30.3 & 43.6 & 0.7 & 26.8 \\
\hline \multirow[t]{2}{*}{ Northern red oak (Quercus rubra) } & 83 & 30.6 & 1.3 & 43.2 & 56.9 & 1.5 & 35.6 \\
\hline & & & & 40.0 & & & 21.7 \\
\hline
\end{tabular}


Table 3.2. Comparison of decay stage by treatment excluding oaks and hickories for plots measured between 2006 and 2012 in the Fernow Experimental Forest.

\begin{tabular}{|c|c|c|c|c|c|c|c|c|c|c|c|c|c|c|c|c|}
\hline Treatment & & & & & & & & De & Stag & & & & & & & \\
\hline $\begin{array}{c}\text { FIRE } \\
n=788\end{array}$ & 1 & $\%$ & 2 & $\%$ & 3 & $\%$ & 4 & $\%$ & 5 & $\%$ & 6 & $\%$ & 7 & $\%$ & CWD & $\%$ \\
\hline 2006 & 719 & 91 & 5 & 1 & 5 & 1 & 16 & 2 & 14 & 2 & 27 & 3 & 1 & 0.00 & 0 & 0.00 \\
\hline 2012 & 326 & 41 & 150 & 19 & 63 & 8 & 29 & 4 & 28 & 4 & 30 & 4 & 0 & 0.00 & 161 & 20 \\
\hline $\begin{array}{c}\text { MIDSTORY } \\
n=782\end{array}$ & 1 & $\%$ & 2 & $\%$ & 3 & $\%$ & 4 & $\%$ & 5 & $\%$ & 6 & $\%$ & 7 & $\%$ & CWD & $\%$ \\
\hline 2006 & 712 & 91 & 5 & 1 & 7 & 1 & 20 & 3 & 11 & 1 & 23 & 3 & 4 & 1 & 0 & 0.00 \\
\hline $\begin{array}{c}\text { OVERSTORY } \\
n=789\end{array}$ & 1 & $\%$ & 2 & $\%$ & 3 & $\%$ & 4 & $\%$ & 5 & $\%$ & 6 & $\%$ & 7 & $\%$ & CWD & $\%$ \\
\hline 2006 & 698 & 88 & 4 & 1 & 10 & 1 & 26 & 3 & 10 & 1 & 37 & 5 & 4 & 1 & 0 & 0.00 \\
\hline 2012 & 5 & 1 & 4 & 1 & 44 & 6 & 189 & 24 & 111 & 14 & 114 & 14 & 11 & 1 & 311 & 39 \\
\hline
\end{tabular}



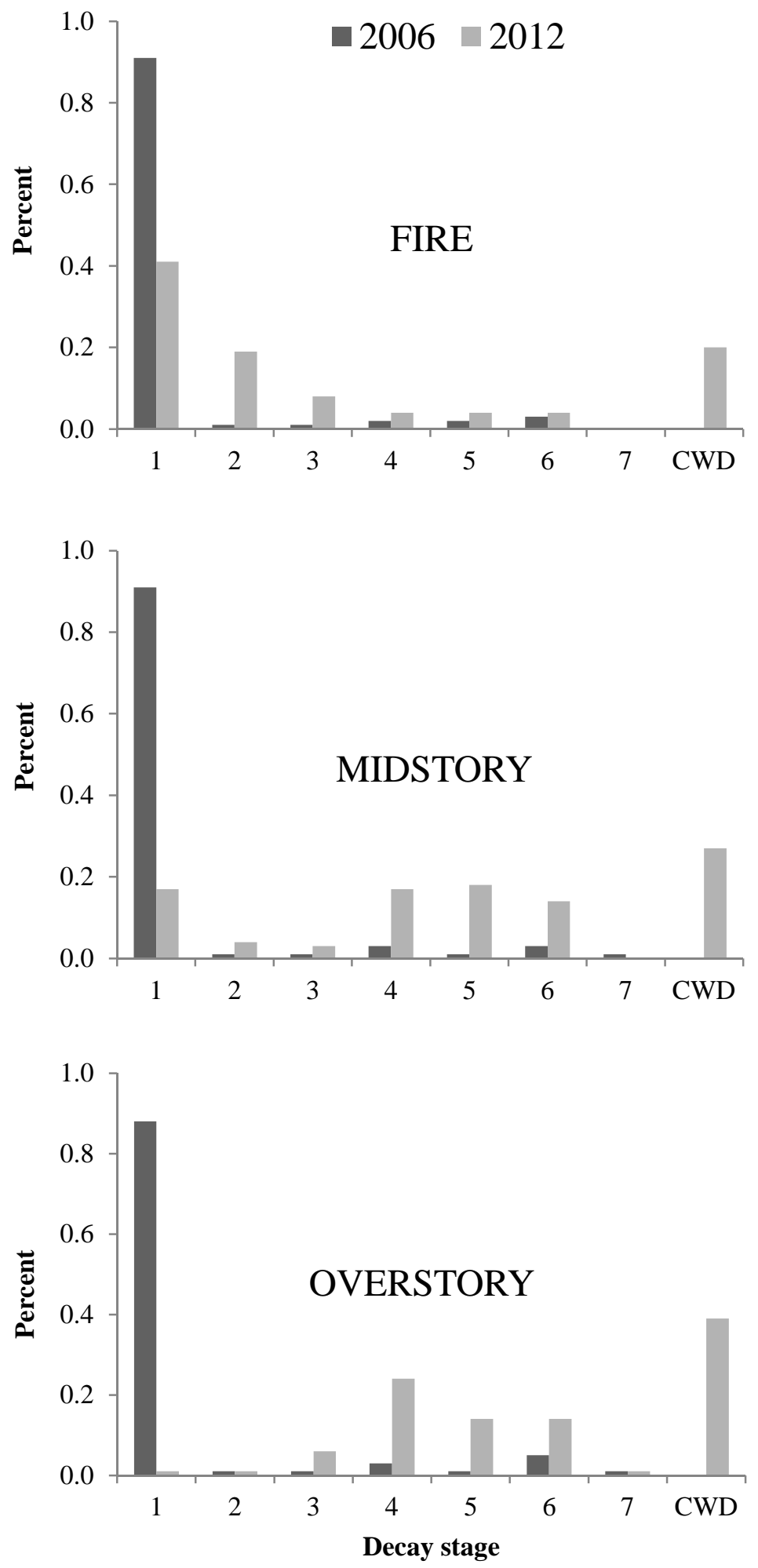

Figure 3.1. Percent trees present in decay stage in 2006 and 2012 and progression among decay stages by treatment type excluding oaks and hickories in the Fernow Experimental Forest, 20062012. 


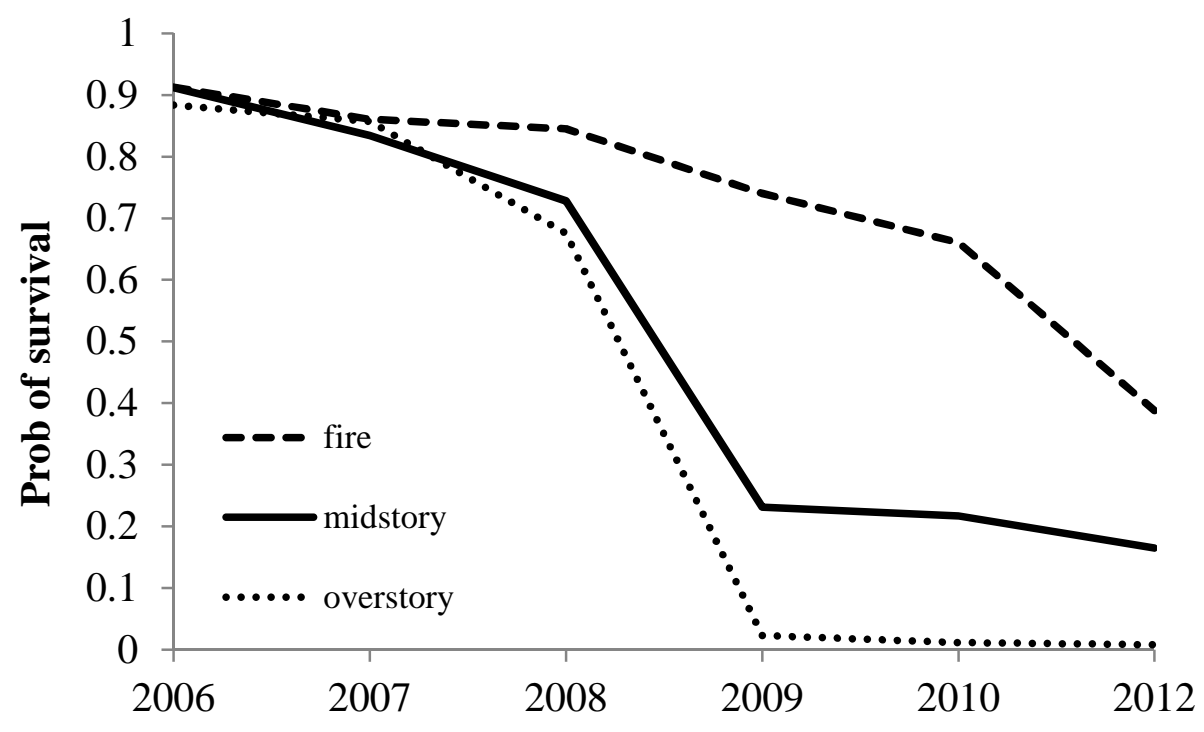

Figure 3.2. Probability of trees excluding oaks and hickories surviving from 2006 to 2012 based on response to one of three treatments, on the FEF. FIRE = fire only; MIDSTORY $=$ fire + herbicide (all non-oaks 12.7-27.9 cm dbh); OVERSTORY = fire + herbicide (all non-oaks 12.7+ $\mathrm{cm})$. 


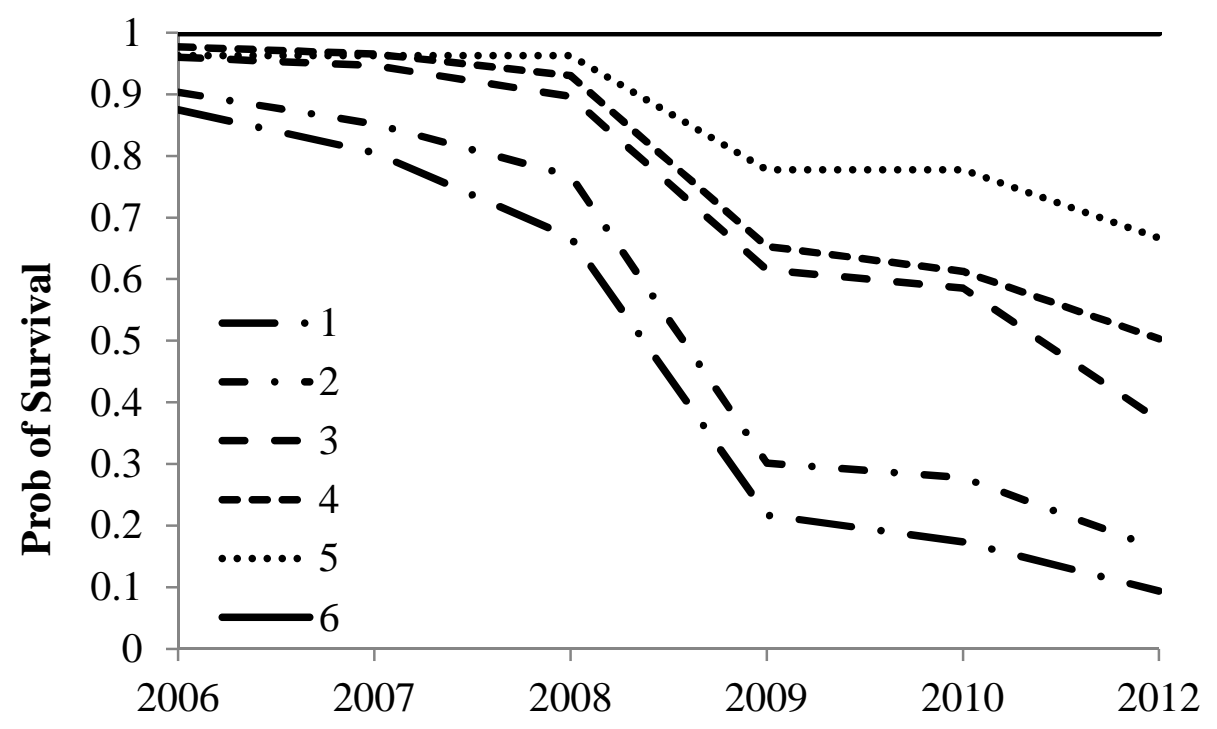

Figure 3.3. Probability of trees excluding oaks and hickories surviving from 2006 to 2012, based on size clas, on the FEF. Size class: $1=12.7-19.9 \mathrm{~cm}, 2=20-29.9 \mathrm{~cm}, 3=30-39.9 \mathrm{~cm}, 4=$ $40-59.9 \mathrm{~cm}, 5=60-79.9 \mathrm{~cm}, 6=80-100 \mathrm{~cm}$. 

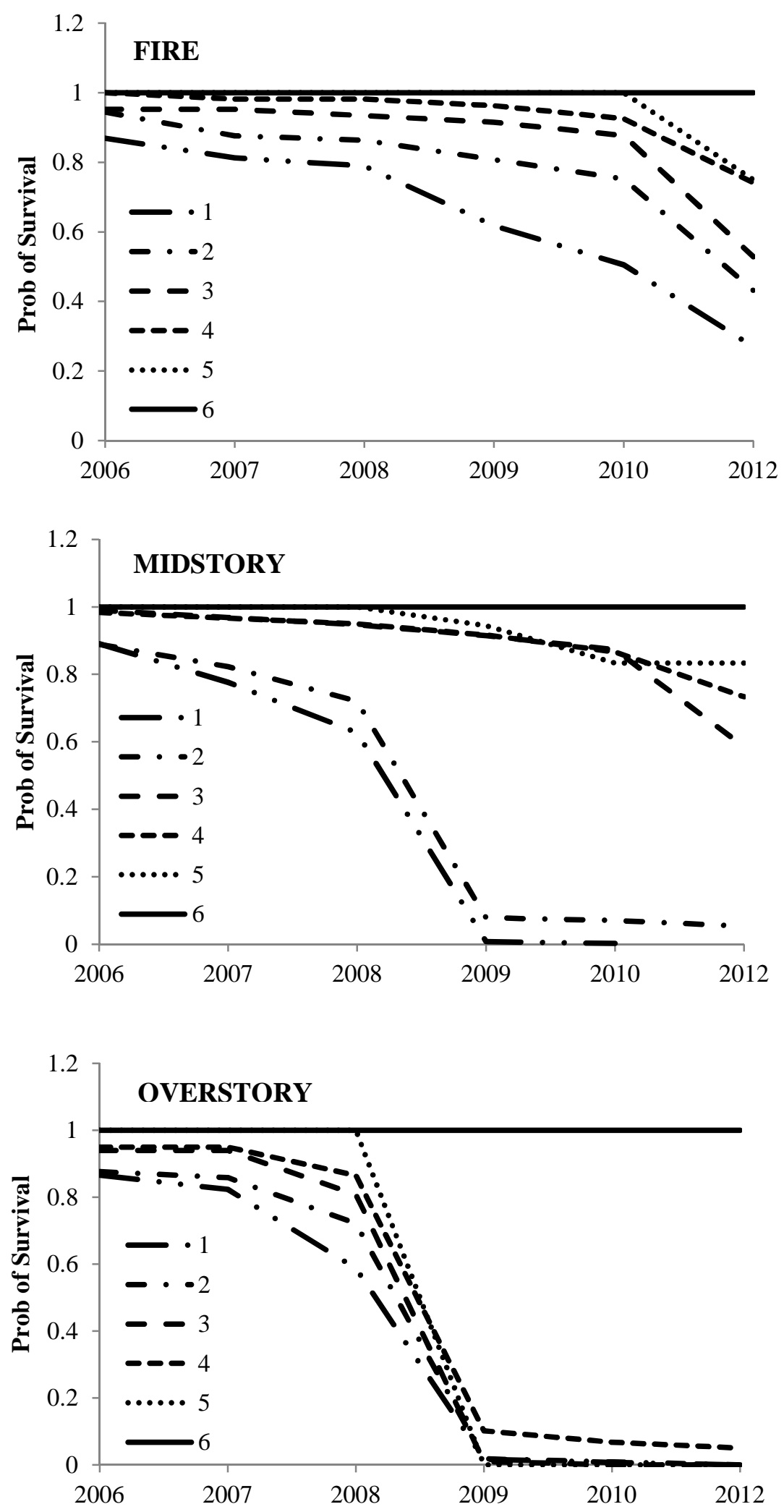

Figure 3.4. Probability of trees excluding oaks and hickories surviving from 2006 to 2012, based on size class within treatment, on the FEF. Size class: $1=12.7-19.9 \mathrm{~cm}, 2=20-29.9 \mathrm{~cm}, 3$ $=30-39.9 \mathrm{~cm}, 4=40-59.9 \mathrm{~cm}, 5=60-79.9 \mathrm{~cm}, 6=80-100 \mathrm{~cm}$. 


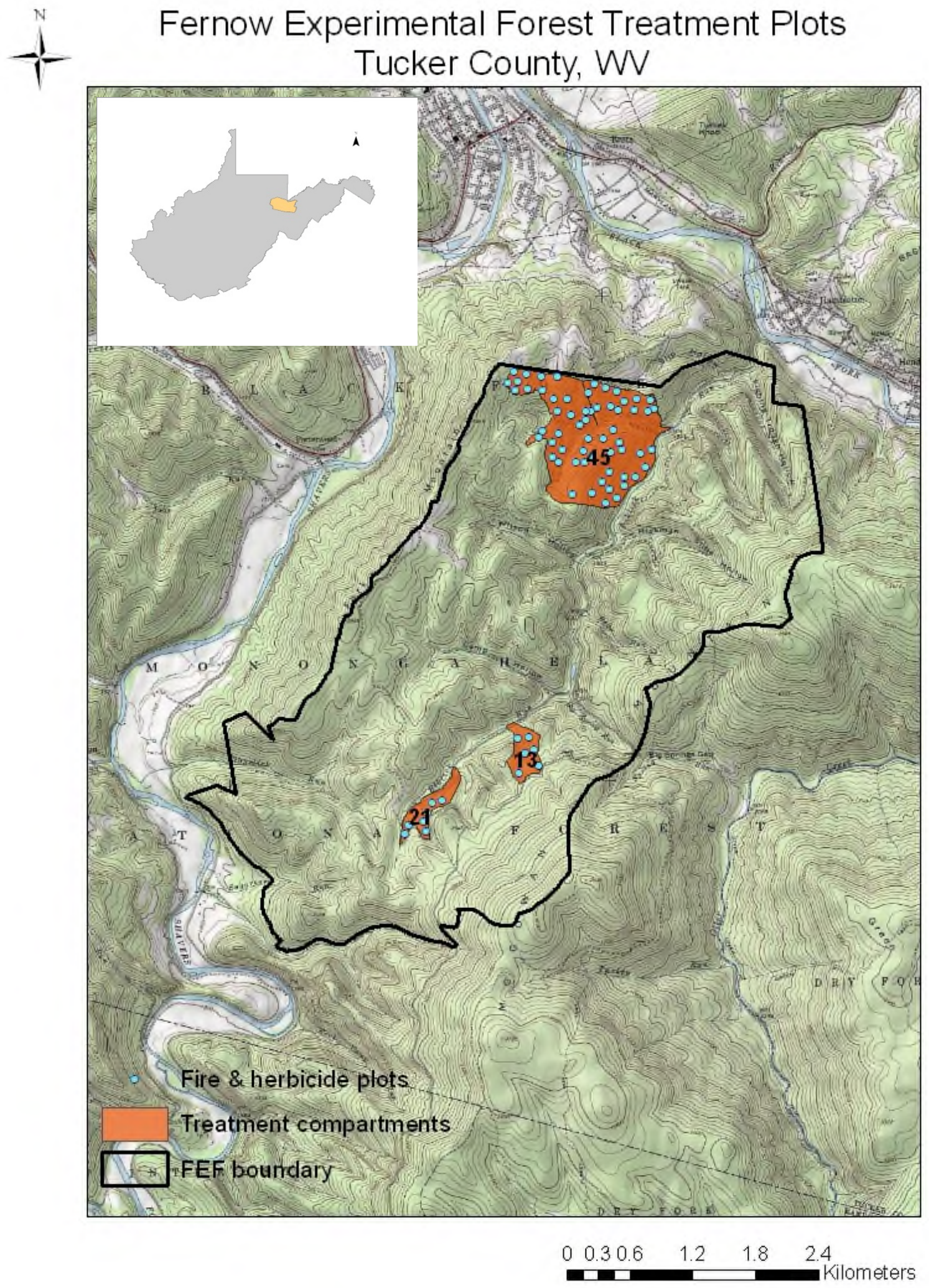

Figure 3.5. Three compartments established in 2006 on the Fernow Experimental Forest and fire/herbicide plots, Tucker County, West Virginia. 
Appendix 3.a. Common species and shade tolerance ratings of trees found in the Fernow Experimental Forest, West Virginia, 2011 and 2012 (Silvics of Forest Trees of the United States, USDA Forest Service 1965).

\begin{tabular}{|c|c|c|c|c|}
\hline Species & Species code & Tolerant & $\begin{array}{c}\text { Mid- } \\
\text { tolerant }\end{array}$ & Intolerant \\
\hline American beech (Fagus grandifolia) & 32 & $\mathrm{X}$ & & \\
\hline Black gum (Nyssa sylvatica) & 85 & $X$ & & \\
\hline Red maple (Acer rubrum) & 79 & $\mathrm{X}$ & & \\
\hline Sugar maple (Acer saccharum) & 76 & $\mathrm{X}$ & & \\
\hline Bitternut hickory (Carya cordiforma) & 21 & & $\mathrm{X}$ & \\
\hline Black oak (Quercus velutina) & 47 & & $\mathrm{X}$ & \\
\hline Chestnut oak (Quercus prinus) & 38 & & $X$ & \\
\hline Cucumbertree (Magnolia acuminata) & 53 & & $\mathrm{X}$ & \\
\hline Northern red oak (Quercus rubra) & 40 & & $\mathrm{X}$ & \\
\hline Shagbark hickory (Carya ovata) & 25 & & $\mathrm{X}$ & \\
\hline Sourwood (Oxydendrum arboreum) & 88 & & $X$ & \\
\hline Sweet birch (Betula lenta) & 29 & & $X$ & \\
\hline White oak (Quercus alba) & 34 & & $X$ & \\
\hline Black locust (Robinia pseudoacacia) & 71 & & & $\mathrm{X}$ \\
\hline Sassafras (Sassafras spp.) & 58 & & & $\mathrm{X}$ \\
\hline Scarlet oak (Quercus coccinea) & 41 & & & $X$ \\
\hline Yellow-poplar (Liriodendron tulipifera) & 56 & & & $X$ \\
\hline
\end{tabular}


Appendix 3.b. Common hardwood species in the Fernow Experimental Forest (>1\% frequency) by vulnerability, to long-term repeated burning (Gleason 1913, Garren 1943, Curtis 1959, Heinselrnan 1973, Grimm 1984, Harmon 1984, Lorimer 1985, Burns and Honkala 1990, Boyer 1990, 1993, Nowacki and Abrams 1992, Orwig and Abrams 1994, Huddle and Pallardy 1996, Hicks 1998, Brose and Van Lear 1998).

\begin{tabular}{|c|c|c|c|}
\hline Very sensitive & Sensitive & Intermediate & Resistant \\
\hline $\begin{array}{c}\text { Sourwood* } \\
\text { (Oxydendron arboreum) }\end{array}$ & $\begin{array}{c}\text { Red maple } \\
\text { (Acer rubrum) }\end{array}$ & $\begin{array}{c}\text { Scarlet oak } \\
\text { (Quercus coccinea) }\end{array}$ & $\begin{array}{l}\text { Hickories } \\
\text { (Carya spp.) }\end{array}$ \\
\hline \multirow[t]{7}{*}{$\begin{array}{c}\text { Black locust* } \\
(\text { Robinia pseudoacacia) }\end{array}$} & $\begin{array}{c}\text { Sugar maple } \\
\text { (Acer saccharum) }\end{array}$ & & $\begin{array}{l}\text { Yellow-poplar (mature) } \\
\text { (Liriodendron tulipifera) }\end{array}$ \\
\hline & $\begin{array}{l}\text { Sweet birch } \\
\text { (Betula lenta) }\end{array}$ & & $\begin{array}{c}\text { White oak } \\
\text { (Quercus alba) }\end{array}$ \\
\hline & $\begin{array}{c}\text { American beech } \\
\text { (Fagus grandifolia) }\end{array}$ & & $\begin{array}{c}\text { Chestnut oak } \\
\text { (Quercus prinus) }\end{array}$ \\
\hline & $\begin{array}{c}\text { Cucumbertree } \\
\text { (Magnolia acuminata) }\end{array}$ & & $\begin{array}{l}\text { Northern red oak } \\
\text { (Quercus rubra) }\end{array}$ \\
\hline & $\begin{array}{l}\text { Fraser magnolia } \\
\text { (Magnolia fraseri) }\end{array}$ & & $\begin{array}{c}\text { Black gum } \\
(\text { Nyssa sylvatica) }\end{array}$ \\
\hline & $\begin{array}{c}\text { Sassafras } \\
\text { (Sassafras spp.) }\end{array}$ & & $\begin{array}{c}\text { Black oak } \\
\text { (Quercus velutina) }\end{array}$ \\
\hline & $\begin{array}{l}\text { American basswood } \\
\text { (Tilia Americana) }\end{array}$ & & \\
\hline
\end{tabular}

*Species added to previous table based on short-term resistance to burning in the FEF, 2006-2012. 
Appendix 3.c. Total and divided area of compartments and areas of treatments by acre and hectare, including percent area of treatment plots established in 2006 in the Fernow Experimental Forest.

\begin{tabular}{lcc}
\hline Compartment & Hectares & \% of total \\
\hline 13 & 13.0 & 8.9 \\
21 & 12.0 & 8.2 \\
45 & 127.0 & 82.9 \\
\cline { 2 - 3 } Total & 152.0 & \\
& & \\
\hline Treatment & Hectares & $\%$ of total \\
\hline Each 20-m radius plot & 0.13 & 0.1 \\
FIRE only plots & 3.0 & 2.0 \\
FIRE + HERBICIDE plots & 6.0 & 3.9 \\
Total plots w/in compartments & 9.0 & 5.9 \\
\hline
\end{tabular}


Appendix 3.d. Decay stage designation and the characteristics of trees in those decay stages (USDA Forest Service based on decay of Douglas-fir snags as adapted by Maser et al. 1979).

\begin{tabular}{ccl}
\hline Decay stage & $\begin{array}{c}\text { Forest Service } \\
\text { code }\end{array}$ & \multicolumn{1}{c}{ Characteristics } \\
\hline 1 & $1-2.15$ & alive (1 = good stem, 2.0 - 2.15 = poor stem) \\
2 & 2.16 & recently dead, declining \\
3 & 2.17 & dead, few limbs missing \\
4 & 2.18 & broken top, loose bark \\
5 & 2.19 & few limbs remaining, no bark \\
6 & 2.20 & broken bole, down material, no limbs \\
7 & 2.21 & decomposed \\
\hline
\end{tabular}


Appendix 3.e. Commonly used crown classes and the characteristics of trees in those classes (Kraft 1884; Oliver and Larson 1990; Smith et al. 1997; Helms 1998).

\begin{tabular}{|c|c|c|}
\hline Crown class & Definition & Characteristics \\
\hline 1 & dominant & $\begin{array}{l}\text { - crown extends above the general canopy layer for the stand } \\
\text { - crown intercepts direct sunlight across the top and along } \\
\text { sides of the upper branches }\end{array}$ \\
\hline 2 & co-dominant & $\begin{array}{l}\text { crown within and helping to form the main crown canopy } \\
\text { for the stand } \\
\text { crown intercepts direct sunlight across the top, but only at } \\
\text { tips of the upper side branches }\end{array}$ \\
\hline 3 & intermediate & $\begin{array}{l}\text { - crown extends somewhat into the lower part of the main } \\
\text { canopy } \\
\text { crown intercepts direct sunlight only at a limited area on } \\
\text { the top and none at the sides }\end{array}$ \\
\hline 4 & suppressed & $\begin{array}{l}\text { - crown entirely below the main canopy and covered by } \\
\text { branches of taller trees } \\
\text { - no direct sunlight strikes at any portion of the crown }\end{array}$ \\
\hline
\end{tabular}


Appendix 3.f. Treatment type used in the three treatment compartments in the FEF (USDA Forest Service).

\begin{tabular}{lcc}
\hline Treatment & \multicolumn{1}{c}{ Characteristics } \\
\hline FIRE & $\bullet$ & prescribed fire only, no herbicide \\
MIDSTORY & $\bullet$ & all non-oaks $12.7-27.9 \mathrm{~cm} \mathrm{dbh}$ treated with herbicide + fire \\
OVERSTORY & $\bullet$ & all non-oaks $>12.7 \mathrm{~cm}$ dbh treated with herbicide + fire \\
\hline
\end{tabular}


Appendix 3.g. Treatment type and timeline of treatment application for 3 compartments in the Fernow Experimental Forest, 2006 - 2012.

\begin{tabular}{ll}
\hline $\begin{array}{l}\text { COMPARTMENT 13 \& 21 } \\
\text { Date }\end{array}$ & Activity \\
\hline 2006 & plots established \& measured \\
& prescribed fire \\
$2007 \mathrm{a}$ & $\begin{array}{l}\text { plots remeasured } \\
\text { herbicide treatment }\end{array}$ \\
$2007 \mathrm{~b}$ & plots remeasured \\
$2007 \mathrm{c}$ & herbicide treatment \\
$2008 \mathrm{a}$ & prescribed fire* \\
$2008 \mathrm{~b}$ & plots remeasured \\
$2009 \mathrm{a}$ & plots remeasured \\
$2009 \mathrm{~b}$ & PLOTS REMEASURED \\
2010 & \\
\hline
\end{tabular}

\begin{tabular}{ll}
\hline COMPARTMENT 45 & Activity \\
Date & plots established \& measured \\
\hline 2006 & prescribed fire \\
$2007 \mathrm{a}$ & plots remeasured \\
$2007 \mathrm{~b}$ & herbicide treatment \\
$2007 \mathrm{c}$ & prescribed fire* \\
$2008 \mathrm{a}$ & plots remeasured \\
$2008 \mathrm{~b}$ & herbicide treatment \\
$2008 \mathrm{c}$ & plots remeasured \\
2009 & plots remeasured \\
2010 & PLOTS REMEASURED \\
2012 & \\
\hline
\end{tabular}

* Compartment 45 received prescribed fire in alternate year from compartments 13 and 21. 
Appendix 3.h. Diameter at breast height (dbh) in $\mathrm{cm}$ of trees found in the Fernow Experimental Forest.

\begin{tabular}{cc}
\hline Size class & Definition \\
\hline 1 & $12.7-19.9 \mathrm{~cm} \mathrm{dbh}$ \\
2 & $20-29.9 \mathrm{~cm} \mathrm{dbh}$ \\
3 & $30-39.9 \mathrm{~cm} \mathrm{dbh}$ \\
4 & $40-59.9 \mathrm{~cm} \mathrm{dbh}$ \\
5 & $60-79.9 \mathrm{~cm} \mathrm{dbh}$ \\
6 & $80-100 \mathrm{~cm} \mathrm{dbh}$ \\
\hline
\end{tabular}

